BHL. 50196 (T-552)

(Health and Safety - TID-4500)

\title{
1966 ENVIRONMENTAL MONITORING RADIATION LEVELS AT BROOKHAVEN NATIONAL LABORATORY
}

\author{
A.P. HULL AND J.T. GILMARTIM
}

September 1969

This report WESAL NOTICE

This report was prepared as an account of work sjonsored by the Inited Stutes Government. Neither the United States nor the United States Atomic Energy Commistion, nor any of their employeutomic Energy their coniractors, ally of their employew, nor any of makes any warranty, expreas or implled, or employees, legal linbilicy or responsibility implied, or nusumes any pletenen or userusonsibility for the mecuracy, comproduct or crocess dicto of any information, apparatus, would not infrisige ort iutely, or represents that its tue 


\section{EGA L NOTICE}

This report was prepared as an account of Government sponsored work. Neither the United States, nor ithe Commission, nor any person acting on behalf of the Cummission:

A. Makes any warranty or representation, expressed or implied, with nespect to the accuracy, completeness, or usefulioess of the information contaiged in this report, or that the use of aty information, apparatus, method, or process disclosed in this report may not infringe privately owned rights; or

B. Assumes any liabilities with respect to the use of, or for damages resulting from the use of any information, apparatus, nethod, or process disclosed in this report.

As used in th : above, "person actirg on behalf of the Commission" includes any employee or contractor of the Commission, or employce of such contractor, to the extent that such employee or contractor of the Commission, or employee of such contractor prepares, disseminates, or provides access to, any information pursuant to his eniplesy. ment or contract with the Commission, or his employment with such contractor.

\section{Printed in the United States of Amerisa}

$$
\text { Available from }
$$

Clearinghouse for Federal Scientific and Technical Informatior.

National Bureau of Standards, U.S. Department of Commerce

Springfield, Virginia 22151

Price: Printed Copy \$3.00; Microfiche \$0.65

Ju!y 1970 


\section{ABSTRACT}

Measurements of "natural background" radiation levels and of increments attributable to Laboratory operations obtained on site and in the vicinity of Brookhaven National Laboratory during 1966 are summarized in this report. These increments irzclude contributions from the gaseous and particulate effluents from the stack serving the Brookhaven Graphite Research Reactor and the High Flux Beam Research Reactor, from multicurie field $\gamma$ sources, and from the discharge of low-level liquid wastes from the Laboratory's sanitary waste treatment plant into the headwaters of the Peconic River.

The natural background external radiation levels declined to an average of $1.90 \mathrm{mR} / \mathrm{wk}$ during 1966. The highest yearly on-site level attributable to Laboratory operations was 8.51 $\mathrm{mR} /$ wk (for $168 \mathrm{hr}$ ), well within established radiation protection standards for individuals in controlled areas. The highest yearly average radiation level at the perimeter was $2.49 \mathrm{mR} / \mathrm{wk}$, to which the ecology forest source contributed $1.60 \mathrm{mR} / \mathrm{wk}$, the remainder being from ${ }^{41} \mathrm{Ar}$. The total was $25 \%$ of the established yearly standard of $500 \mathrm{mR}$ for individuals in uncontrolled areas.

No airborne radioactivity attributable to Laboratory operations, other than 131 , was detectable at ground level. The yearly average gross $\beta$ concentration of samples counted after a 54-hr delay (to allow for the decay of natural radioactivity) was $0.15 \mathrm{pCi} / \mathrm{m}^{3}$, with a 1-day maximum of $2.9 \mathrm{pCi} / \mathrm{m}^{3}$ on May 18.

Stack effluent dispersion studies utilizing the routine emission of 131 I from the Graphite Research Reactor were continued during 1966 . The highest yearly arerage was $0.0042 \mathrm{pCi} / \mathrm{m}^{3}$, which may be compared with the radiation protection standard of $100 \mathrm{pCi} / \mathrm{m}^{3}$ in uncontrolled areas. Fallout ${ }^{131} \mathrm{I}$ from foreign weapons tests was apparent in an average concentration of $0.0420 \mathrm{pCi} / \mathrm{m}^{3}$ between May 14 and 27 and of $0.0200 \mathrm{pCi} / \mathrm{m}^{3}$ between Oct. 28 and Dec. 2 .

The gross $\beta$ activity in precipitation declined slightly to a monthly average of $7.3 \mathrm{nCi} / \mathrm{m}^{2}$ and the average concentration to $111 \mathrm{pCi} /$ liter. The largest daily collection, $22.3 \mathrm{nCi} / \mathrm{m}^{2}$ in a concentration of $3560 \mathrm{pCi} /$ liter, was made on Nov. 6.

Liquid wastes totaling $35.4 \mathrm{mCi}$ were discharged to the headwaters of the Peconic River in an average gross $\beta$ concentration of $32 \mathrm{pCi} / \mathrm{liter}$. This was $3 \%$ of a calculated radiation protetion standard which assumed that the ${ }^{50} \mathrm{Sr}$ fraction was $20 \%$ and that the other isotopes piesent were "unknown" $\beta$ or $\gamma$ emitters. In ajdition, $3.5 \mathrm{Ci}$ of tritium was discharged in an average concentration of $3.2 \mathrm{nCi} /$ liter. This was $0.1 \%$ of the applicable radiation protection standard. The average grows $\beta$ concentration of morthly "grah" samples froin downstrearn on the Peconic ranged from 15 to $4 \mathrm{pCi} /$ liter, while those from off-site control locations averaged $7 \mathrm{pCi} /$ liter. 'The avirage trititiu concentrations for the Peconic River and control locations were all $<1$ a( ii/liter. 'I'he highest concentration of individual isotopes in bottom sediment, $10.2 \mathrm{pCi} / \mathrm{g}$ of HIC and $12.9 \mathrm{prii} / \mathrm{g}$ of ${ }^{137} \mathrm{Cs}$, were found at the Laboratory's perimeter. The highest concentrations in one species of vegetation (Valisneria americana), $4.2 \mathrm{pCi} / \mathrm{g}$ of 605.0 and $30 \mathrm{pCi} / \mathrm{g}$ of ${ }^{1 / 7}\left(\mathrm{is}\right.$, were found on sile near the perimeter. Concentrations of ${ }^{60} \mathrm{Co}$ in both sediment and vegetation cleclined to near-background beyond a point about a mile downstream from the Laboralory's perimeter. 'The situation for ${ }^{137} \mathrm{Cs}$ was not as defined in vegetation and turtle kamples.

'I'he concentrations of ${ }^{1: 11}$ I in milk were generally leas than the minimum level of detection ( $\because \mathrm{p}$ (:i/liter) except fos a few weeks after the May and October foreign weapons tests. The applis'able radiation protection guide, asuming an intake of $1 \mathrm{liter} /$ day, is $100 \mathrm{pCi} /$ liter.

The Euvironmental Monitoring Program has established that during 1966 radiation levels atcributable to I aboratory operations were maintained well below the established radiation protection standarda of the AEC fror external expowurea and for concentrationy of radioactivity in air and water. Radiarion levels attributable to fallout were alw well below eatablished standurds. 


\section{ENVIRONMENTAL MONITORING RÃDIATION LEVELS AT BROOKHAVEN NATIONAL LABORATORY}

\section{INTRODUCTION}

Brookhaven National Laboratory is situated on Long Island, about 70 miles east of New York City. Its location with regard to surrounding communities is shown in Figure 1. Except for shoreline communities, most of the land area within ten miles is either forested or under cultivation. Environmental monitoring data have been obtained in the vicinity of the Laboratory since 1949. Annual reports ${ }^{1-4}$ of this information were instituted in 1962 to make both the fallout data and the results of the investigations of local effects available to interested persons.

The evaluation of radiation levels in the vicinity of the Brookhaven National Laboratory site is performed by the Environmental Monitoring Section of the Health Physics Division. Laboratory operations rontribute three principal additions to the local natural background radiation: gaseous and particulate radioactivity contained in the effluent cooling air of the Brookhaven Graphite Research Reactor (BGRR), the High Flux Beam Research Reactor (HFBR), the Medical Research Reactor (MRR), and the off-gas of the Hot Laboratory (discharged froin the BGRR-HFBR stack); radiation from two multicurie field $\gamma$ sources; and low-level radioactivity contained in liquid wastes released io a small stream that forms one of the headwaters of the Peconic River.

Natural background and radiation levels attributable to Laboratory operations during 1966 are summarized in this report. Although substantially reduced from the record 1963 levels, sorne residual fallout from the atmospheric testing of nuclear weapons during 1961 and 1962 was observed during 196\% in many types of environmental samples. Some fresh fission products were also evident for several months after the Chinese weapons tests in May and October. ${ }^{5,6}$ While fallout is measured primarily to separate it from the Laboratory's contribution to the environment, such information about fallout radioactivity levels as has been obtained is also summarized.
Among the data reported are external exposures, air particulate concentrations, rain and settled dust collections, milk and grass concentrations, liquid effluent concentrations, and water, silt, and vegetation concentrations in off-site streams.

\section{EXTERNAL EXPOSURE MONITORING}

Environmental radiation levels, including natural background (as influenced by fallout) and the increments attributable to reactor cooling-air effluent and to the multicurie field $\gamma$ sources, were monitored continuously at six fixed monitoring stations and seasonally at five additional stations. As shown in Figure 2, one of these continuous stations was on site and four were at the perimeter. Off-site station O-6, at $8.7 \mathrm{~km}$ and $168^{\circ}$ downwind from the BGRR-HFBR stack, is not shown. The seasonal stations were located in a line downwind from the stack for the prevailing southwesteriy wind from May to September and for the prevail. ing northwesterly wind from November to March. Each seasonal line included one continuously operated perimeter station.

Included in each station'y equipment was an ion chamber and dynaruic capacitor electrometer assembly, described in detail elsewhere. These units are capable of accurately measuring $<10$ $\mu R / h r$ and of detecting changes of the order of $1: 4 \mathrm{R} / \mathrm{hr}$. Although information about the isstantaneous dose rates up to about $0.5 \mathrm{mk} / \mathrm{hr}$ may be obtained from these units, normally the integrated radiation over 4-hr periods was used to obtair. weekly averages, and these in turn were used to compute the monthly data tabulated in this section.

Monthly average grous external radiation levels are set forth in Table 1. For convenience in making comparisons in this and immediately fol lowing summaries, the stations have been grouped according to location on site, at the perimeter, and off site.

Since the eatablished radiation protection standard ${ }^{8}$ of $500 \mathrm{mR} / \mathrm{yr}$ for individuals living in the vicinity of the Laboratory is in addition to natural 


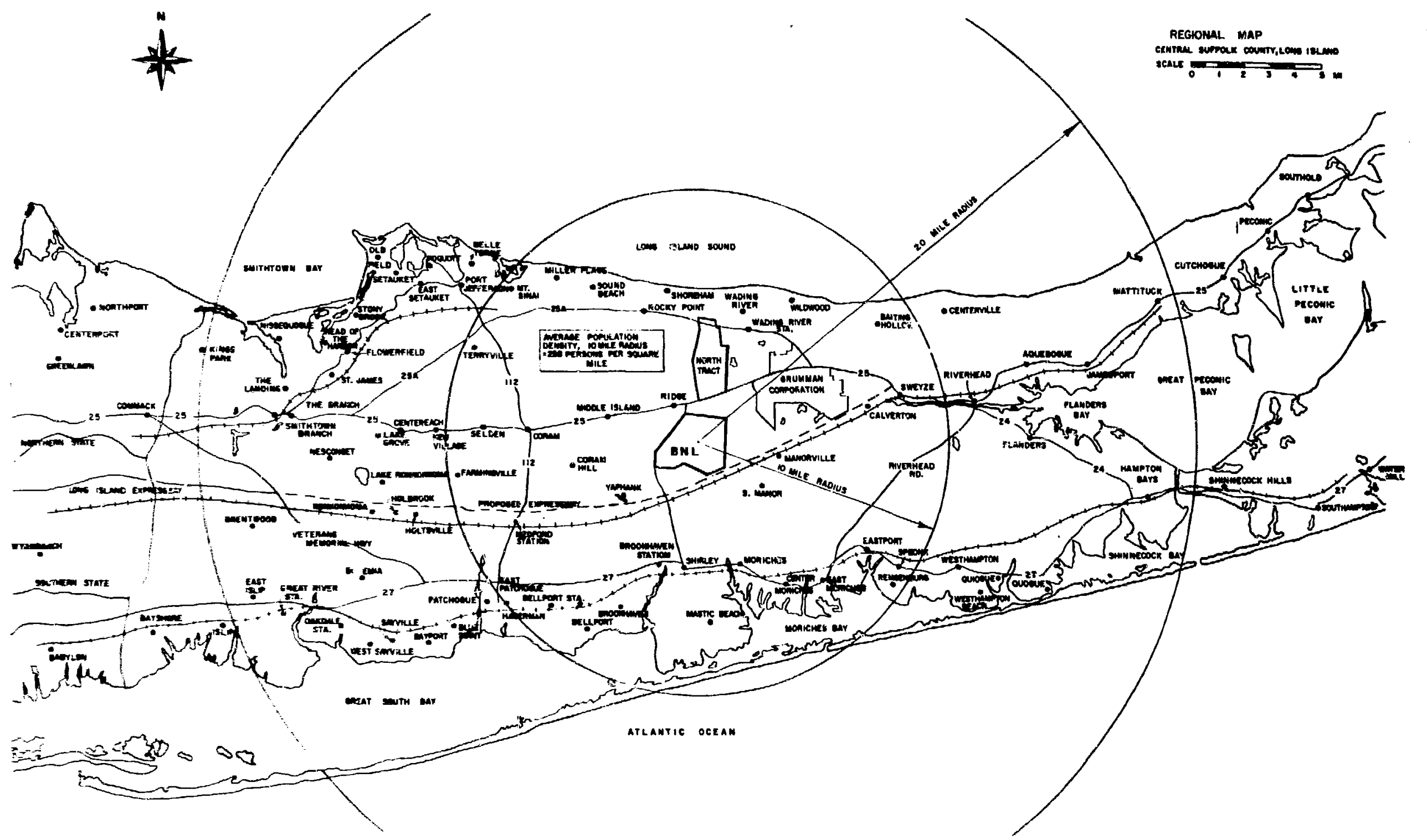

Figure 1. Central Suflolk County, showing the area around Brookhaven National Laboratory. 


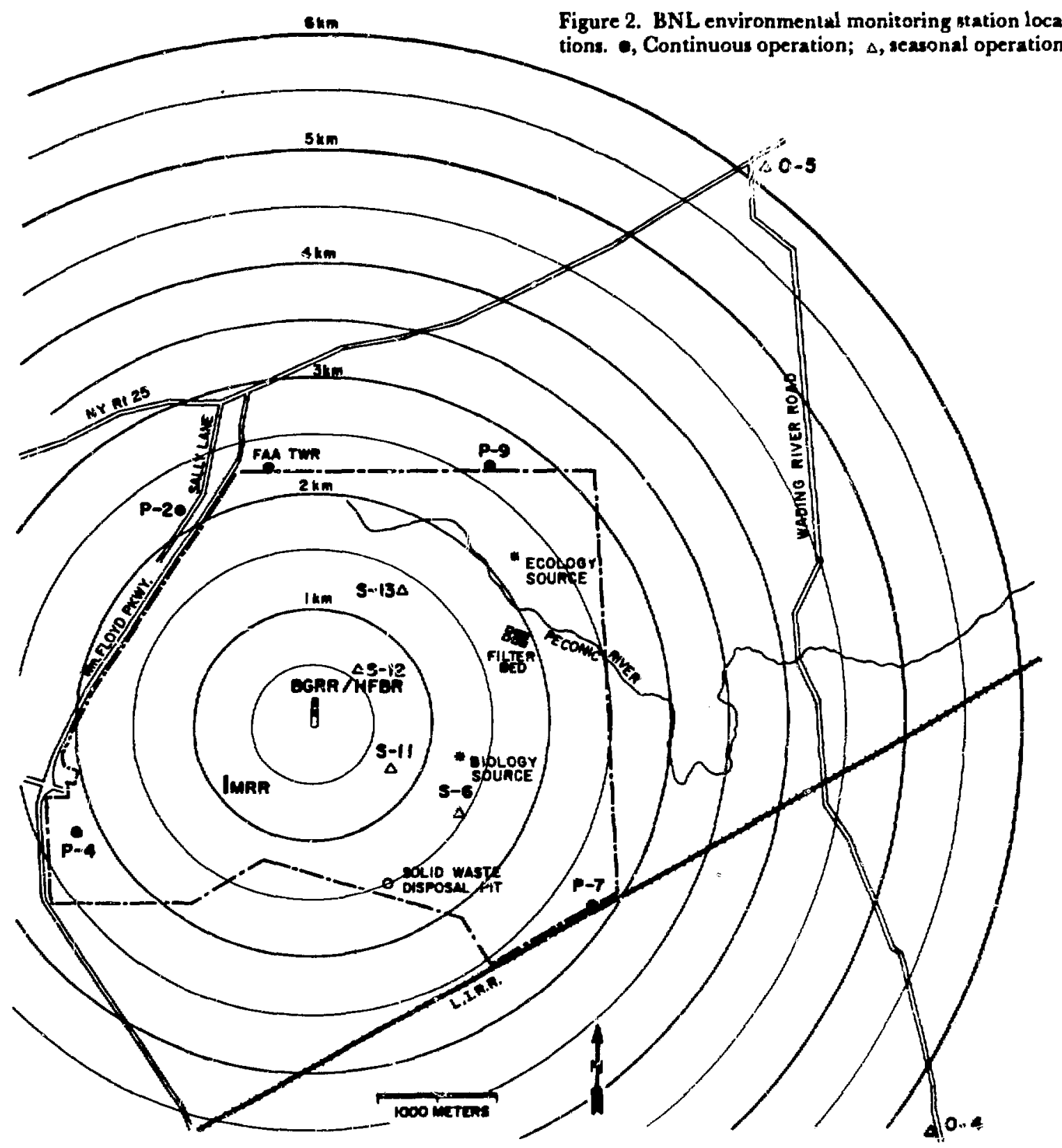

background, determinations of the latter are routinely made. Natural background levelis, as measured by 6-liter atmonpheric-premure ion chambers which retlect some deposition of fallout radioactivity, are reported in Tabie 2. Yearly natural background levels (including fallout) from the initiation of coservations at the Laboratory in 1949 to the present are indicated in Figure 3. The data prior to 1964 have been adjusted to take into axcount the change in elevution of the ion chambers from 6 in. to $2 \mathrm{ft}$ above the roof of each moni-

toring station. Background radiation levels declined to the lowent level oberved sirice 1961.

Natural background at given station was dr:termined from the radiation level prevailing when no obvious Laboratory contributions were detectable at a mtation. The subjective error in making thin determinatio. was minimized by relerence to metcorological duta (to eutublish the direction of the reactor plume) and to the log indications of down hours of the field $\gamma$ sources. 
The only measurable increase above natural background attributable to Laboratory operations at most of the monitoring stations was caused by the activated 4'Ar component of the BGRR-HFBR effluent cooling air. As indicated in Table 3, Kanne chamber measurements showed an average ${ }^{11} \mathrm{Ar}$ stack concentration of $1.84 \times 10^{-3} \mu \mathrm{Ci} / \mathrm{cm}^{3}$ during 1966. The daily discharge of 110 -min half-life ${ }^{41} \mathrm{Ar}$ was $19,300 \mathrm{Ci} /$ day when the BGRR was in operation at close to $20 \mathrm{MW}$. As of July 1, 1966, the BGRR was scheduled to shut down every weekend beginning at 1800 hr on Friday and to start

Table 1

1966 BNL Enviranmental Monitoring Monthly Average Gross Radiation Levels, mR/wk

\begin{tabular}{|c|c|c|c|c|c|c|c|c|c|c|c|}
\hline \multirow[b]{2}{*}{ Month } & \multicolumn{4}{|c|}{ On site } & \multicolumn{4}{|c|}{ Perimeter } & \multicolumn{3}{|c|}{ Off site } \\
\hline & S. 6 & $5-11$ & S-12 & $S-13$ & P-2* & P-4 & P-7 & P.9 & $0-4$ & $0-5$ & 0.6 \\
\hline Jan. & 89.3 & 12.42 & - & - & 1.95 & 1.95 & 3.10 & 3.57 & - & - & 1.78 \\
\hline Feb. & 87.2 & 10.82 & - & - & 2.01 & 1.69 & 2.24 & 3.80 & - & - & 1.61 \\
\hline Mar. & 94.3 & 9.45 & - & - & 2.06 & 1.75 & 2.08 & 3.84 & 1.69 & - & 1.74 \\
\hline Apr. & 87.3 & 9.72 & - & 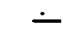 & 2.10 & 1.82 & 2.20 & $\mathbf{4 . 0 0}$ & 1.61 & - & 1.74 \\
\hline May & - & 11.12 & - & - & 2.46 & 2.10 & 2.42 & 4.43 & - & - & 1.88 \\
\hline June & - & 12.46 & - & - & 2.21 & 2.12 & 2.17 & 5.73 & - & 2.83 & 1.85 \\
\hline July & - & 11.82 & 5.04 & 5.57 & 2.29 & 1.92 & 2.27 & 5.78 & - & 2.38 & 1.97 \\
\hline Aug. & - & 10.93 & 5.36 & 5.34 & 2.33 & 1.97 & 2.25 & 5.76 & - & 2.38 & 2.04 \\
\hline Sept. & - & 10.61 & 3.55 & $\mathbf{3 . 8 0}$ & 2.32 & 2.40 & 2.05 & 4.57 & - & 2.19 & 1.90 \\
\hline Oct. & - & 11.33 & 3.42 & 3.62 & 2.26 & 2.04 & 2.47 & 4.01 & - & 2.11 & 1.80 \\
\hline Nov. & - & 8.46 & - & 4.53 & 1.77 & 1.95 & 1.89 & 4.55 & - & - & 1.73 \\
\hline Dec. & - & 8.33 & - & 3.31 & 1.78 & 2.04 & 1.87 & 3.67 & - & - & 1.70 \\
\hline Av & 89.5 & 10.62 & $4: 34$ & 4.36 & 2.13 & 1.98 & 2.25 & 4.48 & 1.60 & 2.38 & 1.81 \\
\hline
\end{tabular}

Estimated error (monthly average): $\mathbf{\pm 3 \%}$

"Station was shut down Oct. 14, moved from Sally Lane to FAA Tower location, and started up Nov. 4

Táble 2

1966 BNL Environmental Monitoring Monthly Average Background Levels, mR/wk

\begin{tabular}{|c|c|c|c|c|c|c|c|c|c|c|c|c|}
\hline \multirow[b]{2}{*}{ Month } & \multicolumn{4}{|c|}{ On site } & \multicolumn{4}{|c|}{ Perimeter } & \multicolumn{3}{|c|}{ Off site } & \multirow{2}{*}{$\begin{array}{c}\text { All } \\
\text { stations } \\
\text { av* }\end{array}$} \\
\hline & S-6 & S-11 & S-12 & S-13 & P-2* & P-4 & P-7 & P-9 & O-4 & 0.5 & $0-6$ & \\
\hline Jan. & 2.0 & 2.22 & - & - & 1.90 & 1.76 & 2.03 & 2.03 & - & - & 1.78 & 1.95 \\
\hline Feb. & 1.9 & 2.23 & - & - & 1.85 & 1.65 & 1.84 & 2.00 & - & - & 1.61 & 8.86 \\
\hline Mar. & 1.8 & 2.03 & - & - & 1.80 & 1.66 & 1.83 & 1.89 & 1.52 & - & 1.68 & 1.82 \\
\hline Apr. & 1.8 & $\Xi .06$ & -- & - & 2.02 & 1.74 & 1.92 & 2.04 & 1.53 & - & 1.72 & 1.91 \\
\hline May & - & 2.09 & - & - & 1.87 & 1.68 & 1.88 & 1.83 & - & - & 1.72 & 1.84 \\
\hline June & - & 2.08 & - & - & 2.03 & 1.73 & 1.88 & 1.93 & - & 1.89 & 1.79 & 1.91 \\
\hline July & - & 1.96 & 1.93 & 2.01 & 2.21 & 1.82 & 2.08 & 2.12 & - & 1.89 & $1 . \$ H$ & 2.012 \\
\hline Aug. & - & 1.97 & 1.97 & 2.04 & 2.23 & 1.80 & 2.03 & 2.10 & - & 1.86 & 1.97 & 2.02 \\
\hline Sept. & - & 1.89 & 2.01 & 1.94 & 2.11 & 1.83 & 1.92 & 2.08 & - & 1.95 & 1.86 & 1.95 \\
\hline Oct. & - & 1.76 & 2.05 & 1.96 & 2.12 & 1.90 & 1.90 & 1.98 & - & 1.93 & 1.79 & 1.94 \\
\hline Nov. & - & 1.80 & - & 1.99 & 1.71 & 1.87 & 1.87 & 1.94 & - & - & 1.73 & $1.2 !$ \\
\hline Dec. & - & 1.75 & - & 1.89 & 1.61 & 1.80 & 1.80 & 1.91 & - & - & 1.67 & 1.76 \\
\hline Av & 1.9 & 1.98 & 1.99 & 1.99 & 1.96 & 1.77 & 1.92 & 1.99 & 1.52 & $1.90)$ & 1.77 & $1 .(n)$ \\
\hline
\end{tabular}

Estimated error: $\pm 0.15 \mathrm{mR} /$ wk.

-Station was shut down Oct. 14, moved from Sally Lane to FAA Tower location, and started up Nov. 4.

* Seasonally operated stations not included in monthly averages. 
up at 0001 hr Monday morning, with nominal 20-MW operation attained by noon on Monday. The MRR stack concentration of ${ }^{41} \mathrm{Ar}$ is $3.0 \times 10^{-4}$ $\mu \mathrm{Ci} / \mathrm{cm}^{3}$, and the discharge is $75 \mathrm{Ci} / 24-\mathrm{hr}$ day at full power ( $3 \mathrm{MW}$ ); however, the MRR was infrequently operated at this power level or duty cycle. About $5 \mathrm{Ci} / \mathrm{wk}$ were discharged from its

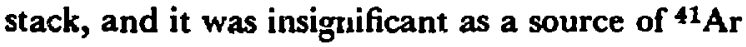
when compared with the BGRR. The yearly av-

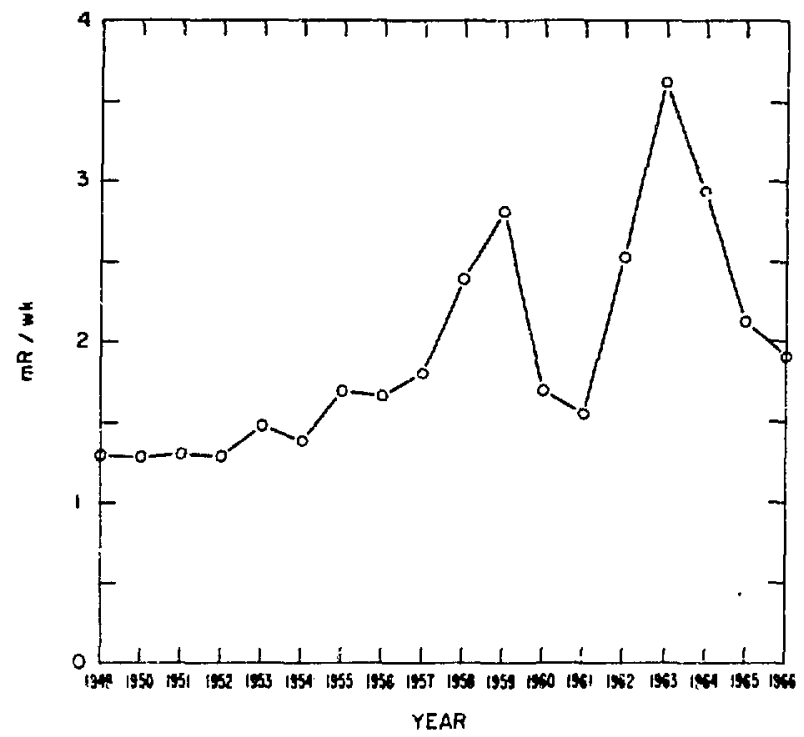

Figure 3. Yearly average background at elevation of $3 \mathrm{ft}, 1949-6 \hat{6}$. erage radiation levels, in $\mathrm{mR} / \mathrm{wk}$, attributable to ${ }^{41} \mathrm{Ar}$ at each of the monitoring stations are shown in Table 4. A decrease in the monthly ${ }^{41}$ Ar levels was apparent at most stations during the second half of the year. The overall yearly average at the six continously operated stations was $94 \%$ of that for 1965, while the number of MWd of reactor operation was $95 \%$ of that for 1965 . The percentage frequencies of wind directions to the nesrest $10^{\circ}$ during the years 1961-1963, tabulated by the BNL Meteorology Group, were published in the 1964 report. ${ }^{3}$ The seasonal patterns apparent from these wind roses can be correlated reasonably well with the monthly variations in the ${ }^{41} \mathrm{Ar}$ reported at the individual monitoring stations.

Two multicurie field $\gamma$ sources are routinely exposed $20 \mathrm{hr} /$ day. One, a ${ }^{60} \mathrm{Co}$ source that contained $3080 \mathrm{Ci}$ on Jan. 1, 1966, and was restored to 3600 Ci on June 1, is used primarily for plant irradiations in a cultivated plot. The other, a ${ }^{137} \mathrm{Cs}$ scurce that contained $8000 \mathrm{Ci}$ as of Jan. 1, 1966, is used to irradiate an otherwise undisturbed wooded area for ecologic:al studies. The ${ }^{137} \mathrm{Cs}$ source produced a measuratile dose sate at stations $\mathbf{P}-9$ and $\mathrm{S}-13$, and the ${ }^{60} \mathrm{Co}$ source dose rate was evident at station S-11. Monthly average radiation levels at these stations attributable to the sources are isted in Table 5. With use of a methe suggented by Cowan and Meinhold ${ }^{9}$ and the observed morthly mean temperatures, monthly dose rates have also been calculated. Attenuation by the shield plugs and by

Table 3

1966 BNL Environmental Monitoring

BGRR-HFHR Stack Emission

\begin{tabular}{|c|c|c|c|c|c|c|c|c|c|c|}
\hline \multirow[b]{2}{*}{ Month } & \multirow{2}{*}{$\begin{array}{l}\text { BGRR } \\
\text { MWd }\end{array}$} & \multirow{2}{*}{$\begin{array}{c}\text { Air volume, } \\
\mathrm{cm}^{3}\end{array}$} & \multicolumn{2}{|c|}{${ }^{3} \mathrm{H}$ (HFBR) } & \multicolumn{2}{|r|}{$131 I$} & \multicolumn{2}{|c|}{${ }^{41} \mathrm{Ar}$} & \multicolumn{2}{|c|}{ Particulate } \\
\hline & & & $\mathrm{Ci}$ & $\mu \mathrm{Ci} / \mathrm{cm}^{3}$ & $\mathrm{mCi}$ & $\mu \mathrm{Ci} / \mathrm{cm}^{3}$ & $\mathbf{C i}$ & $\mu \mathrm{Ci} / \mathrm{cm}^{3}$ & $\mathbf{C i}$ & $\mu \mathrm{Ci} / \mathrm{cm}^{3}$ \\
\hline Jan. & 458 & $2.29 x$ & - & - & 189 & $8.23 \times 10$ & $3.8 \times 10^{5}$ & $1.66 \times 1$ & 30 & 1.31 \\
\hline Feb. & 357 & $1.79 \times$ & - & - & 180 & $10.01 \times 10^{-10}$ & $3.6 \times 10^{5}$ & $2.05 \times 10$ & 26 & $1.46 \times 10^{-7}$ \\
\hline Mar. & 455 & $2.43 \times 10^{14}$ & 0.3 & $0.12 \times 10^{-8}$ & 511 & $21.00 \times 10^{-10}$ & $4.7 \times 10^{5}$ & $1.93 \times 1$ & 33 & $1.36 \times 10^{-7}$ \\
\hline Apr. & 443 & $2.54 \times 10^{14}$ & 0.5 & $0.20 \times 10^{-8}$ & 777 & $30.60 \times 10^{-10}$ & $4.5 \times 10^{5}$ & & 27 & $1.06 \times 10^{-7}$ \\
\hline May & 496 & $2.78 \times 10^{14}$ & 0.8 & $0.29 \times 10^{-8}$ & 160 & $5.75 \times 10^{-10}$ & $4.7 \times 10^{5}$ & $1.69 \times 10^{-3}$ & 34 & $1.22 \times 10^{-7}$ \\
\hline June & 556 & $3.25 \times 10^{14}$ & 3.0 & $0.95 \times 10^{-8}$ & 170 & $5.74 \times 10^{-10}$ & $5.3 \times 10^{5}$ & $1.63 \times 1$ & 39 & $1.20 \times 110^{-7}$ \\
\hline July & 296 & $1.50 \times 10^{14}$ & 3.6 & $2.40 \times 10^{-8}$ & 80 & $5.32 \times 10^{-10}$ & $2.9 \times 10^{5}$ & $1.93 \times$ & 21 & $1.40 \times 10^{-7}$ \\
\hline Aug. & 384 & $2.04 \times 10^{14}$ & 7.3 & $3.57 \times 10^{-8}$ & 90 & $4.42 \times 10^{-10}$ & $3.8 \times 10^{5}$ & $1.87 \times 1$ & 27 & $1.33 \times 10^{-7}$ \\
\hline Sept. & 300 & $1.56 \times 10^{14}$ & 5.2 & $3.23 \times 10^{-8}$ & 75 & $4.82 \times 10^{-10}$ & $2.9 \times 10^{5}$ & $1.86 \times 10^{-3}$ & 27 & $1.73 \times 10^{-7}$ \\
\hline Ckt. & 304 & $1.58 \times 10^{14}$ & 8.6 & $5.45 \times \mathrm{iU}^{-8}$ & 90 & $5.75 \times 10^{-10}$ & $2.9 \times 10^{5}$ & $1.83 \times 10^{-3}$ & 19 & $1.20 \times 10^{-7}$ \\
\hline Nov. & 327 & $1.67 \times 10^{14}$ & 4.5 & $2.72 \times 10^{-8}$ & 15 & $4.55 \times 10^{-10}$ & $3.1 \times 10^{5}$ & $1.88 \times 10^{-3}$ & 20 & $1.21 \times 10^{-7}$ \\
\hline Dec. & 301 & $1.50 \times 10^{14}$ & 5.9 & $3.84 \times 10^{-8}$ & 69 & $4.60 \times 10^{-10}$ & $3.0 \times 10^{5}$ & $2.00 \times 10^{-3}$ & 20 & $1.33 \times 10^{-7}$ \\
\hline
\end{tabular}

Annual totai

$467724.93 \times 10^{14} \quad 39.7$

2466

$45.2 \times 10^{5}$

323

Av

$2.28 \times 10^{-8}$

$9.23 \times 10^{-10}$

$1.84 \times 10^{-3}$

$1.32 \times 10^{-7}$ 
lable 4

I'Wwi HNI, Fonvemumental Muniloring

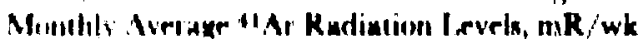

(II) aII:

\begin{tabular}{|c|c|c|c|c|c|c|c|c|c|c|c|}
\hline \multirow[b]{2}{*}{ Minu!! } & \multicolumn{4}{|c|}{ I ll vili: } & \multicolumn{4}{|c|}{ Perinsetrr } & \multicolumn{3}{|c|}{ Off site } \\
\hline & 11 & $S 11$ & S. $1^{3}$ & $N 11$ & $\boldsymbol{\mu} \cdot 2^{*}$ & p.4 & P.7 & $\mathbf{P}-9$ & 0.4 & O-5 & 0.6 \\
\hline JnII & 11 & I N & & & 0.05 & 0.19 & 1.07 & $0 .: 32$ & - & - & 0.01 \\
\hline Fill & 111 & $\therefore 111$ & $\therefore$ & & $11.11 \mathrm{i}$ & 0.104 & $(0.40$ & 0.62 & $-m$ & - & 0 \\
\hline Mal & 1. & 111 & & & 0.20 & 0.0 .9 & 0.2 .5 & 0.63 & 0.07 & - & 0.07 \\
\hline Yil & 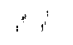 & $\therefore$ & & $\cdots$ & 0.013 & $0.0 \mathrm{AB}$ & 0.29 & 0.50 & 0.08 & - & 0.02 \\
\hline Mal & & $: 711$ & & & 0.5 .4 & 0.42 & 0.54 & 1,08 & - & - & 0.16 \\
\hline finer & & $: 111$ & & & {$[3.18$} & 0.39 & 0.28 & 2.03 & - & 0.94 & 0.07 \\
\hline loils. & & $1 . . \mathrm{mI}$ & $\because \mathrm{H} . \mathrm{l}$ & 215 & A. $18 \mathrm{H}$ & 0.10 & 0.19 & 1.47 & - & 0.49 & 0.01 \\
\hline $\operatorname{lin}$ & & 11 & 111 & $\geq 11$ & 0.10 & 0.17 & 0.22 & 1,62 & - & 0.52 & 0.07 \\
\hline Self & & $\|$ व배 & $1: 11$ & 11311 & 0.21 & 0.57 & 0.14 & 0.55 & - & 0.23 & 0.04 \\
\hline 14 & & $\because 11$ & $1: 1$ & 01,1 & 0.14 & 0.14 & 0.57 & 0.30 & - & 0.18 & 0.01 \\
\hline vin & & II 1,1 & & $1 \%$ & $11.06 \mathrm{i}$ & 0.08 & 0.02 & 1.21 & - & - & 0 \\
\hline Int & & 1131 & & $\| R$ & 0.17 & 0.24 & 0.07 & 0.40 & - & - & 0.04 \\
\hline $1:$ & 1 & $1: 111$ & $1|A|$ & $14 H$ & 0.17 & 0.21 & 0.34 & 0.89 & 0.08 & 0.47 & 0.04 \\
\hline
\end{tabular}

Fatintaled Monthly Average Error

\begin{tabular}{|c|c|}
\hline mK wh & Error, $\%$ \\
\hline 0.02 & \pm 100 \\
\hline 0.020 .05 & \pm 50 \\
\hline 0.080 .25 & \pm 25 \\
\hline$\times(1.2 !)$ & \pm 10 \\
\hline
\end{tabular}

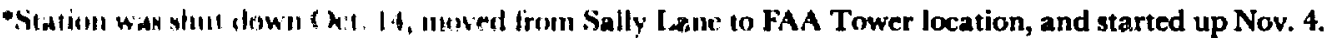

Table 5

1966 BNI. Environmental Monitoring

Monthly Average Radiation Ieveln From Écology Forest Source at Stations P-9, S-13, and S-11, 1nR/wk

\begin{tabular}{|c|c|c|c|c|c|c|c|c|c|c|c|}
\hline \multirow[b]{2}{*}{ Month } & \multicolumn{2}{|c|}{ Mean ' } & \multicolumn{3}{|c|}{ P.ga } & \multicolumn{3}{|c|}{$S-13 b$} & \multicolumn{3}{|c|}{ S-11: } \\
\hline & ${ }^{c} \mathbf{F}$ & ${ }^{\circ} \mathrm{C}$ & Obs. & Calc. & Otbs./Calc. & Obs. & Calc. & Obs./Calc. & Obs. & Calc. & Obs./Calc. \\
\hline Jan. & 27.8 & -2.3 & 1.22 & 1.85 & 0.66 & - & - & - & 5.70 & 7.18 & 0.79 \\
\hline Feb. & 29.9 & -1.2 & 1.18 & 1.84 & 0,64 & - & - & - & 5.56 & 7.34 & 0.76 \\
\hline Mar. & 37.7 & 3.2 & 1.32 & 1.95 & 0.68 & - & - & - & 5.64 & 7.74 & 0.73 \\
\hline Apr. & 42.5 & 5.8 & 1.47 & 2.12 & 0.69 & - & - & - & 5.19 & 8.19 & 0.62 \\
\hline May & 53.0 & 11.7 & 1.52 & 2.33 & 0.65 & - & - & - & 6.24 & 9.75 & 0.64 \\
\hline June & 66.0 & 18.9 & 1.77 & 2.68 & 0.66 & - & - & - & 7.37 & 12.30 & 0.60 \\
\hline July & 72.4 & 22.4 & 2.19 & 2.93 & 0.75 & 1.24 & 2.28 & 0.56 & 8.16 & 12.90 & 0.64 \\
\hline Aug. & 70.0 & 21.1 & 2.04 & 2.82 & 0.72 & 1.14 & 2.25 & 0.51 & 7.69 & 12.40 & 0.62 \\
\hline Sept. & 60.5 & 15.8 & 1.95 & 2.80 & 0.70 & 1.07 & 2.06 & 0.52 & 7.27 & 11.34 & 0.64 \\
\hline Det. & 48.6 & 9.2 & 1.73 & 2.22 & 0.78 & 1.05 & 1.88 & 0.56 & 6.91 & 10.00 & 0.70 \\
\hline Nov. & 44.0 & 6.7 & 1.39 & 2.10 & 0.66 & 0.84 & 1.41 & 0.60 & 6.34 & 9.34 & 0.68 \\
\hline Dec. & 31.0 & -0.5 & 1.36 & 1.80 & 0.75 & 0.75 & 1.36 & 0.55 & 6.28 & 8.14 & 0.77 \\
\hline Av & 48.6 & 9.2 & 1.60 & 2.29 & 0.70 & 1.02 & 1.87 & 0.55 & 6.53 & 9.72 & 0.68 \\
\hline
\end{tabular}

Estimated error (observed data): $\pm 7.5 \%$. 
Table 6

1966 BNL Environmental Monitoring

Ion Chamber Comparison, $\mathrm{mR} / \mathrm{hr}$

\begin{tabular}{lcc}
\hline Location & $\begin{array}{c}\text { BNI. shielded } \\
\text { chamber (wall } \\
2825 \mathrm{mg} / \mathrm{cm}^{2} \\
\text { thick) }\end{array}$ & $\begin{array}{c}\text { NYS Dept. of } \\
\text { Health chamber } \\
\text { (wall } \approx 2500 \\
\text { mg/cm }\end{array}$ \\
\hline $\begin{array}{c}\text { 7th St. and } \\
\text { Brookhick) }\end{array}$ \\
$\begin{array}{l}\text { Sewer plant } \\
\text { ive. }\end{array}$ & 0.020 & 0.020 \\
\hline
\end{tabular}

the surrounding woods is suggested as the most probable explanation for the lower radiation levels observed. The reason for the difference between the average ratio of observed to calculated dose at stations at comparable distances from the sources is not obvious but is perhaps related to the limitations of the niethod of calculation.

Some radiation from the ${ }^{60} \mathrm{Co}$ source also reaches on-site station $\mathrm{S}-12$, but the amount is too small to be measured accurately in the presence of the much higher ${ }^{11} \mathrm{Ar}$ levels usually observed at this location. A calculated correction for the source effect was applied to obtain the natural background measurements at station S-12.

The cylindrical ion chambers used in making the above measurements have a sensitive volume of 6 liters and operate at atmospheric pressure. They have Bakelite side walls $\approx 400 \mathrm{mg} / \mathrm{cm}^{2}$ thick. The ends are much thicker and may be considered essentially $\beta$-opaque. In November 1965 an intercomparison between the BNL ion chamber and an 8-liter, high-pressure, Ar-filled chamber with a $2500-\mathrm{mg} / \mathrm{cm}^{2}$-thick steel wall belonging to the New York State Department of Health indicated that about $30 \%$ of the background dose rate measured by the BNL chamber was attributable to $\beta$ or soft- $\gamma$ radioactivity not detectable by the high-pressure chamber.

In February 1966 the response to ${ }^{60} \mathrm{Co}$ and ${ }^{226} \mathbf{R a}$ sources of the standard chamber $(400-\mathrm{mg}$ / $\mathrm{cm}^{2}$-thick wall) was compared with that of a chamber having a $2825-\mathrm{mg} / \mathrm{cm}^{2}$-thick wall and an outer lining of steel. Baciground averages inferred from the two sources were virtually identical $\left(10.3 \mu \mathrm{R} / \mathrm{hr}\right.$ for ${ }^{60} / \mathrm{co}$ and $10.2 \mu \mathrm{R} / \mathrm{hr}$ for ${ }^{226} \mathrm{Ra}$ ). The background as measured with the thick-wolled chumber averaged $90 \%$ of that of the thin walled chamber with ${ }^{\circ} \mathrm{Co}$ calibration, and $96 \%$ with ${ }^{226} \mathrm{Ra}$ calibration.

On Aug. 24, 1966, measurements were madc of the external background radiation levels at the BNI, ioin chamber, shieited by $1 /$-in. steel, and the
Table 7

1966 BNL Environmental Monitoring

Average Concentrations of ${ }^{22} \mathrm{Br},{ }^{131}$, and ${ }^{133} \mathrm{I}, 10^{-8} \mu \mathrm{Ci} / \mathrm{cm}^{3}$

\begin{tabular}{|c|c|c|c|}
\hline Month & $\mathbf{2} \mathbf{B r}$ & $1: 111$ & 133I \\
\hline June & 4.1 .3 & 0.58 & 1.36 \\
\hline July & 6.5 .5 & 0.50 & 4.50 \\
\hline Aug. & 5.8 .5 & 0.22 & 3.42 \\
\hline Sept. & 3.5 .3 & 0.40 & 1.74 \\
\hline Oct. & 4.144 & 0.52 & 3.69 \\
\hline Nov. & 4.86 & 0.34 & 2.76 \\
\hline Dec. & 3.44 & 0.32 & 1.21 \\
\hline Av conc. & 4. $\mathrm{HI}^{2}$ & 0.44 & 2.67 \\
\hline $\begin{array}{l}\text { Emiseion ralr, } \\
\mu \mathrm{Ci} / \text { wet }\end{array}$ & $(1,(x)$ & 6.0 .5 & 0.32 \\
\hline
\end{tabular}

high-premure chumb being uned by the New York State Department of Health for field surveys in the BNL area. 'The rewults are compaced in Table 6. The agreement is quite satiafactory and strongly mggesti that previoubly obeerved dierrepancies between the New York State Department of Health observations of background in this vicinity and those made by the BNL Environmental Monitoring Section are principaliy attributable to the difference in ion-chamber wall thickneas.

\section{STACK-DTUNT AND CNOUNDLVA AM PARTICULATE AND RADIONOOME: MONTOANO}

Routine monitoring of the BGRR-HFBR stack effluent is conducted by the Reactor Health Physics Group. The equipment used includes an air particulate sampler with a continuous tape of filter medium (HV-70), which moves past a $\beta$ scintillation detector at 20 min post collection, to determine the air particulate gross $\beta$ concentration; a Sill-type charcoal cartridge ${ }^{10}$ which was routinely changed every other day and counted in $a \mathrm{NaI}$ well detector 1 wk post collection to determine 131I effluent concentrations; and a silica-gel trap to collect water vapor for weekly liquid scintillation analysis for ${ }^{3} \mathrm{H}$. The average monthly gross $\beta,{ }^{131} \mathrm{I}$, and ${ }^{3} H$ concentrations in the BGRR-HFBR stack effluent, as established by this routine sampling program, are shown in Table 3.

In June 1966, the Environmental Monitoring Section undertook the daily $\gamma$ analysis of an independently obtained stack air particulate and charcoal sample pack. This was done primarily to determine the feasibility of detecting some of the shorter lived stack effluent nuclides at ground level and thereby to establish their usefulness as tracers 
Table 8

1966 BNL Environmental Monitoring

Average Concentrations of Intermediate and Long-Lived $\gamma$-Emitting Isotopes in BGRK Stack Eftluent, $\mathrm{pCi} / \mathrm{m}^{3}$

\begin{tabular}{|c|c|c|c|c|c|c|c|c|c|c|c|}
\hline \multirow{3}{*}{$\begin{array}{l}\text { Sample } \\
\text { component }\end{array}$} & \multicolumn{10}{|c|}{ Activation isotopes } & \\
\hline & \multicolumn{2}{|c|}{${ }^{\circ 0 \mathrm{Co}}$} & \multicolumn{2}{|c|}{$\cos \mathrm{Zn}$} & \multicolumn{2}{|c|}{${ }^{75} \mathrm{Se}^{*}$} & \multicolumn{2}{|c|}{${ }^{124} \mathrm{Sb}$} & \multicolumn{2}{|c|}{${ }^{203} \mathrm{Hg}$} & \\
\hline & Conc. & $\%$ & Done. & $\%$ & Conc. & $\%$ & Conc. & $\%$ & Conc. & $\%$ & \\
\hline $\begin{array}{l}\text { Particulate } \\
\text { Chsrcoal }\end{array}$ & $\begin{array}{l}1.2 \\
0.1\end{array}$ & $\begin{array}{r}94 \\
6\end{array}$ & $\begin{array}{l}7.6 \\
0.4\end{array}$ & $\begin{array}{r}95 \\
5\end{array}$ & $\begin{array}{l}0.4 \\
3.3\end{array}$ & $\begin{array}{r}8 \\
91\end{array}$ & $\begin{array}{l}2.1 \\
0.3\end{array}$ & $\begin{array}{l}85 \\
15\end{array}$ & $\begin{array}{r}1.0 \\
14.7\end{array}$ & $\begin{array}{r}6 \\
94\end{array}$ & \\
\hline Total & 1.3 & 100 & 8.0 & 100 & 3.7 & 100 & 2.4 & 100 & 15.7 & 100 & \\
\hline
\end{tabular}

Fission product isotopes

\begin{tabular}{|c|c|c|c|c|}
\hline${ }^{95} \mathrm{Zr}-{ }^{-5} \mathrm{Nb}$ & ${ }^{103} \mathrm{Ru}$ & ${ }^{106} \mathbf{R u}$ & 191I & ${ }^{137} \mathrm{Cs}_{s}$ \\
\hline
\end{tabular}

$\begin{array}{crrrrrrrrrrrrrrrr}\text { Particulate } & 1.4 & 83 & 2.5 & 61 & 1.1 & 83 & 27 & 5 & 2.4 & 91 & 11.2 & 26 & 1.0 & 13 & 1.7 & 19 \\ \text { Charcoal } & 0.3 & 17 & 1.6 & 39 & 0.2 & 17 & 504 & 95 & 0.3 & 9 & 32.1 & 74 & 7.1 & 87 & 7.3 & 81 \\ \text { Total } & 1.7 & 100 & 4.1 & 100 & 1.3 & 100 & 531 & 100 & 2.7 & 100 & 43.3 & 100 & 8.1 & 100 & 9.0 & 100\end{array}$

*Identification tentative.

Table 9

1966 BNL Environmental Monitoring

Monthly Average Grows $\beta$ and $\gamma$-Emitting Isotope Concentrations, Air Particulate Filters, $\mathrm{pri} / \mathrm{m}^{3}$

\begin{tabular}{|c|c|c|c|c|c|c|c|c|c|c|c|c|c|c|}
\hline Month & Groses $\beta$ & $\operatorname{Max}$ & Min & ${ }^{7} \mathrm{Be}$ & ${ }^{54} \mathbf{M n}$ & 125Sb & $\begin{array}{l}{ }^{95} \mathrm{Zr} \text { - } \\
{ }^{95} \mathrm{Nb}\end{array}$ & ${ }^{103} \mathbf{R u}$ & ${ }^{106} \mathrm{Ru}$ & 131 I & ${ }^{137} \mathrm{Cs}$ & $\begin{array}{l}140 \mathrm{Ba}- \\
140 \mathrm{La}\end{array}$ & ${ }^{141} \mathrm{Ce}$ & ${ }^{144} \mathrm{Ce}$ \\
\hline Jan. & 0.067 & 0.135 & 0.014 & 112 & 0.0 & 0.002 & 0.001 & $<0.001$ & 0.010 & $<0.001$ & 0.008 & $<0.001$ & $<0.001$ & 0.004 \\
\hline Feb. & 0.054 & 0 & 006 & 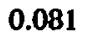 & 0.0 & 0.002 & 0.001 & $<0.001$ & 0.004 & $<0.001$ & 0.005 & $<0.001$ & $<0.001$ & 0.002 \\
\hline Mar. & 0.081 & 0.163 & 0.022 & 0.141 & 0.002 & 0.003 & $<0.001$ & $<0.001$ & 0.004 & $<0.001$ & 0.008 & $<0.001$ & $<0.001$ & 0.006 \\
\hline Apr. & 0.087 & 0.210 & 0.036 & 0.145 & 0.002 & 0.003 & $<0.001$ & $<0.001$ & 0.006 & $<0.001$ & 0.010 & $<0.001$ & $<0.001$ & 0.007 \\
\hline May" & 0.108 & 0.146 & 0.075 & 0.173 & 0.003 & 0.006 & $<0.001$ & $<0.001$ & 0.016 & $<0.001$ & 0.020 & $<0.001$ & $<0.001$ & 0.012 \\
\hline Mayb & 0.393 & 2.9 & 0.147 & 0.1 & 0. & 0.0 & 9 & 26 & 0.016 & 0.042 & 0.0 & 57 & 0.017 & 1.012 \\
\hline June & 0.272 & 0.72 & 0.078 & 0.1 & 1 & 4 & 0.027 & 0.018 & 0.009 & 0.006 & 0.012 & 0.037 & 0.011 & 0.014 \\
\hline July & 0.1 & 0.296 & 0.081 & 0.1 & 0.001 & 0.004 & 0.023 & 0.015 & 0.015 & $<0.001$ & 0.012 & 0.011 & 0.013 & 0.008 \\
\hline Aug. & 0.098 & 0.200 & 0.033 & 0.141 & 0.001 & 0.001 & 0.005 & $<0.001$ & 0.011 & $<0.001$ & 0.005 & $<0.001$ & 0.004 & 0.004 \\
\hline Sept. & 0.100 & 0.314 & 0.023 & 0.147 & 0.001 & 0.001 & 0.004 & $<0.001$ & 0.006 & $<0.001$ & 0.006 & $<0.001$ & 0.002 & 0.004 \\
\hline Oct. & 0.053 & 0.196 & 0.018 & 0.084 & $<0.001$ & 0.001 & 0.001 & $<0.001$ & 0.005 & 0.001 & 0.003 & $<0.001$ & $<0.001$ & 0.006 \\
\hline Nov. & 0.325 & 1.174 & 0.026 & $0.100^{c}$ & $<0.001$ & $<0.001$ & 0.027 & 0.023 & 0.003 & 0.020 & 0.002 & 1 & 0.014 & 0.005 \\
\hline Dec. & 0.070 & 0.229 & 0.030 & 0.115 & $<0.001$ & $<0.001$ & 0.006 & 0.007 & 0.001 & 0.002 & 0.001 & 0.005 & 0.003 & 0.002 \\
\hline Av & 0.146 & 0.526 & 0.053 & 0.124 & 0.001 & 0.003 & 0.010 & 0.007 & 0.008 & 0.006 & 0.008 & 0.014 & 0.005 & 0.007 \\
\hline \multicolumn{15}{|c|}{ Estimated error, \% } \\
\hline & & 10 & \pm 25 & \pm 10 & \pm 50 & \pm 50 & \pm 25 & \pm 25 & \pm 25 & \pm 50 & \pm 25 & \pm 25 & \pm 50 & \pm 25 \\
\hline
\end{tabular}

Aprii 29-May 13.

bMay 14-27.

cEstimated. 
to supplement previous longer term studies of stack-effluent dispersion phenomena which utilized its ${ }^{131}$ I component.

From examination of the data, it appeared that 21-hr ${ }^{133 I}$ and $35-\mathrm{hr}{ }^{82} \mathrm{Br}$ were the only nuclides with useful half-lives (several hours to a few dayss) that were present in the stack effluent in sufficient concentratiors to lead to guantifiable grnund-level rollections. Sirse initial counts of the complete pack showed little day-to-day variation in $82 \mathrm{Br}$ and ${ }^{133}$ I concentrations, representative samples were selected to establish monthly and long-term averages. These are indicated in Table 7 , as are the concentrations of 131 I determined by this method. The latter are in good agreement with those determined by the Reactor Health Physics Group (Table 3).

The packs were subsequently disassembled and the individual components again analyzed to establish the concentrations of longer lived nuclides. Those $>1 \mathrm{pCi} / \mathrm{m}^{3}$ are shown in Table 8 . Additional details and the results of a full year's study (June 1966 - May 1967) of stack effluent are to be published elsewhere. 11
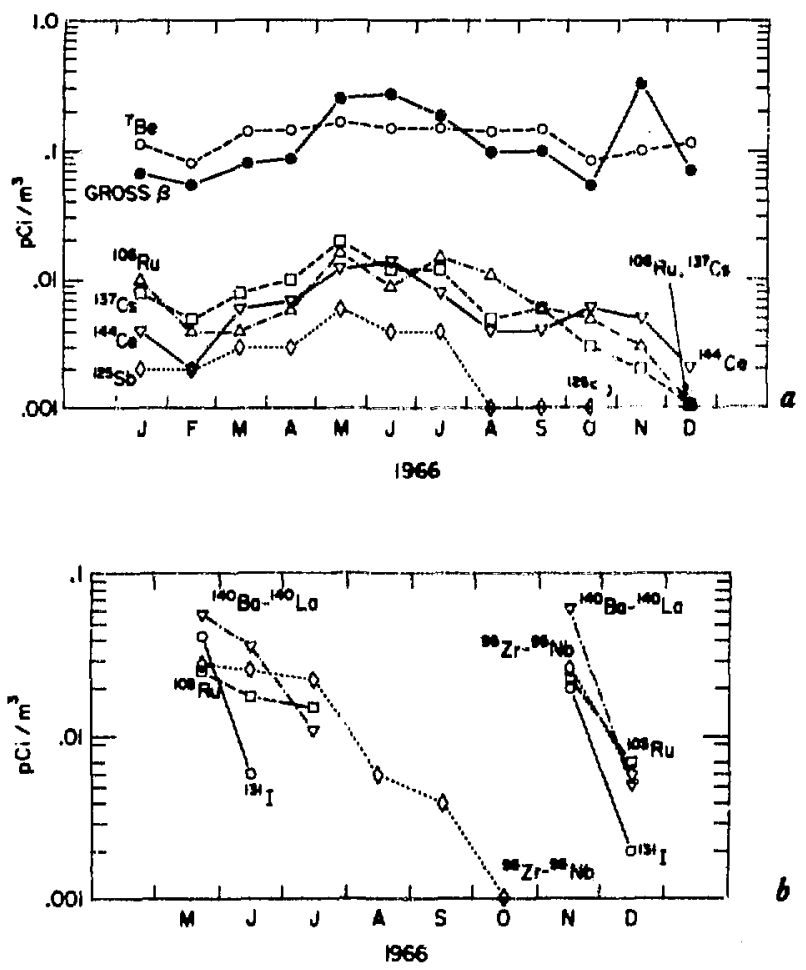

Figure 4. Monthly average concentrations: $a$, long-lived air particulates; $b$, thort-lived air particulates.
During 1966 "high volume" (20 $\left.\mathrm{ft}^{3} / \mathrm{min}\right)$ poeitive displacement air pumps (Gast 3040) were operated at all the active monitoring stations (Figure 2). The air sampling media conuisted of a 3-in.diam air particulate filter (Jan.-July, MSA C17651; Aug.-Dec., Gelman Type G) followed by: a $3 \times 1$-in. bed of petroleum-based rharcoal (Columbia Grade LC $12 / 28$ X mesh) for sampling radiosodine. One particulate filter wist changed and counted on a daily basis. All other samplers were routinely operated on a 2-wk change cycle.

Gross $\beta$ counts of the air particulate samples were made with use of a 2-in.-diam end-window GM tube. A 2-in.-diam section of the filters wes counted at about $54 \mathrm{hr}$ post collection. This delay was introduced to minimize the contribution from the naturally occurring ${ }^{212} \mathrm{~Pb}$ (10.6-hr half-life) thoron daughter. A $\gamma$ analysis was routinely made on a composite of filter samples from the seasonally downwind stations, and another on a composite from the remaining stations. Monthly average 54-hr-delay gross $\beta$ concentrations and those of all identifiable (concentration $>10^{-3} \mathrm{pCi} / \mathrm{m}^{3}$ ) $\gamma$-emitting nuclides are listed in Table 9. The seasonal trend of concentrations of long-lived nuclides and the inputs of fresh shorter lived nuclides are evident from Fizures $4 a$ and 46. Initial calculations of intermediate-lived isotopes have been adjusted for the presence of longer lived isotopes with overlapping photopeaks in the same spectrum. The longer lived isotopes were evaluated by a recount of composite monthly samples after a 1-yr delay. The number of photopeak traneactions attributable to the amount of longer lived isotopes, such as those from 1-yr ${ }^{106} \mathrm{Ru}$ at $0.51 \mathrm{MeV}$ and 285-day ${ }^{144} \mathrm{Ce}$ at $0.13 \mathrm{MeV}$, that ahould have been present in the initial count was then caiculated and subtracted from the total initial photopeak count of the same energy (within the rewolution of the $4 \times 2$ in. NaI detector). The concentrations of 39-day ${ }^{103} \mathrm{Ru}$ at $0.50 \mathrm{MeV}$ and $33-\mathrm{day}{ }^{141} \mathrm{Ce}$ at $0.15 \mathrm{MeV}$ were determined from the net initial photopeak count. When ${ }^{140 B a-140} \mathrm{La}$ appeared to be present, a "stripping" procedure (using a magnetic tape of

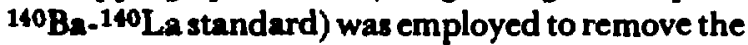
several interfering photopeaks of this isotope prior to evaluation of the amounts of other isotopes present in air particulate samples.

A "spring maximum" related to the exchange to the troposphere from the stratospheric reservoir of "aged" nuclear debris was apparent in the monthly concentrations of longer lived nuclides. 


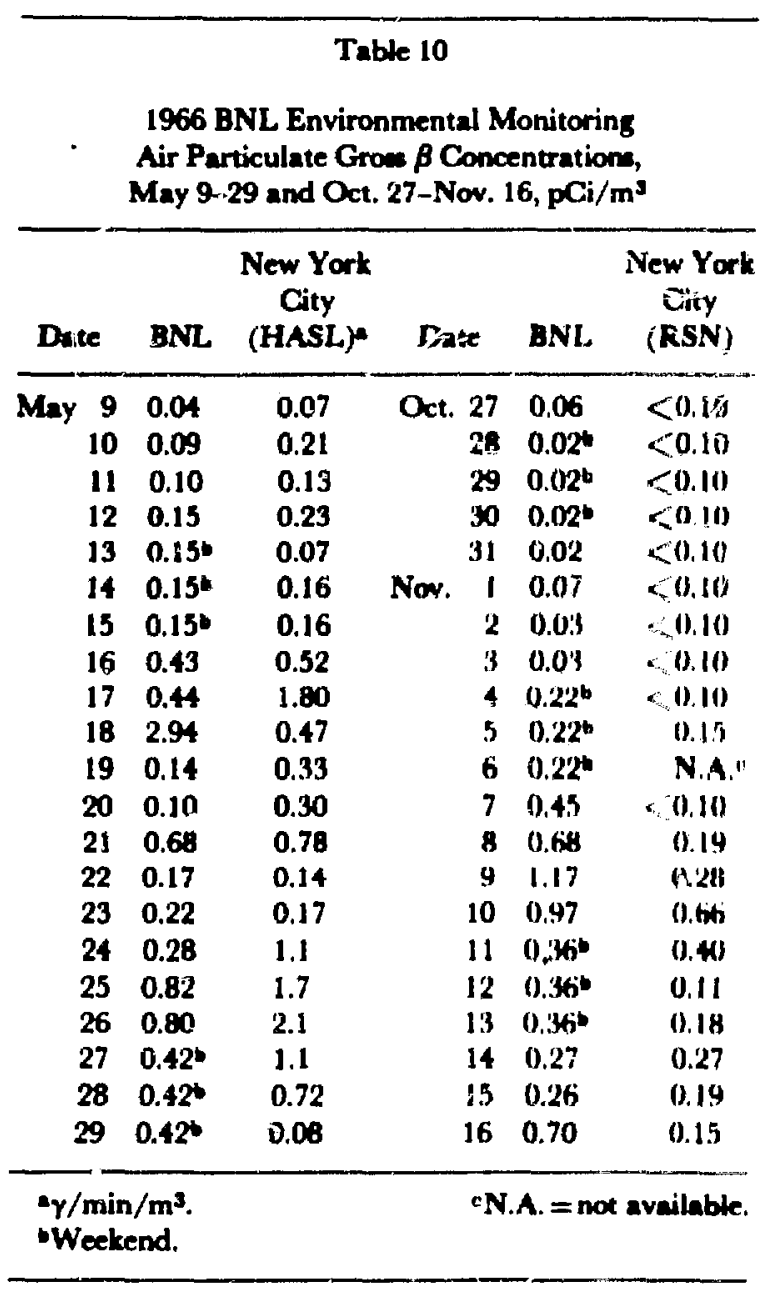

An inpu: of freah fiesion products shortly after esch of the reported May and October Chinese weapon. tests was ales apparent. Although a third Chinese teat 12 was roported to have been conducted late in December, fivion products atuributable to this teat did not appear in local air samples during 1966.

Since the preceding concentrations were minimal, the arrival of debris after each teat was evident in daily measurements of gros $\beta$ concentrations. Those for the three weeks after each reported test are indicated in Table 10, as are similar data obtained at New York City by the U.S. Atomic Energy Commimion's Health and Safety Laboratory (HASL) ${ }^{13}$ and by the U.S. Public Healtt's Service Radiation Surveillance Network (RSN). ${ }^{14}$ The May data are consistent with an analysis by Grundy and Snavely 15 of the intrusion pattern of fallout from the third Chineac teat.

Although the arrival of a sharp pcak in concentration took from 9 to 13 days, in both cases

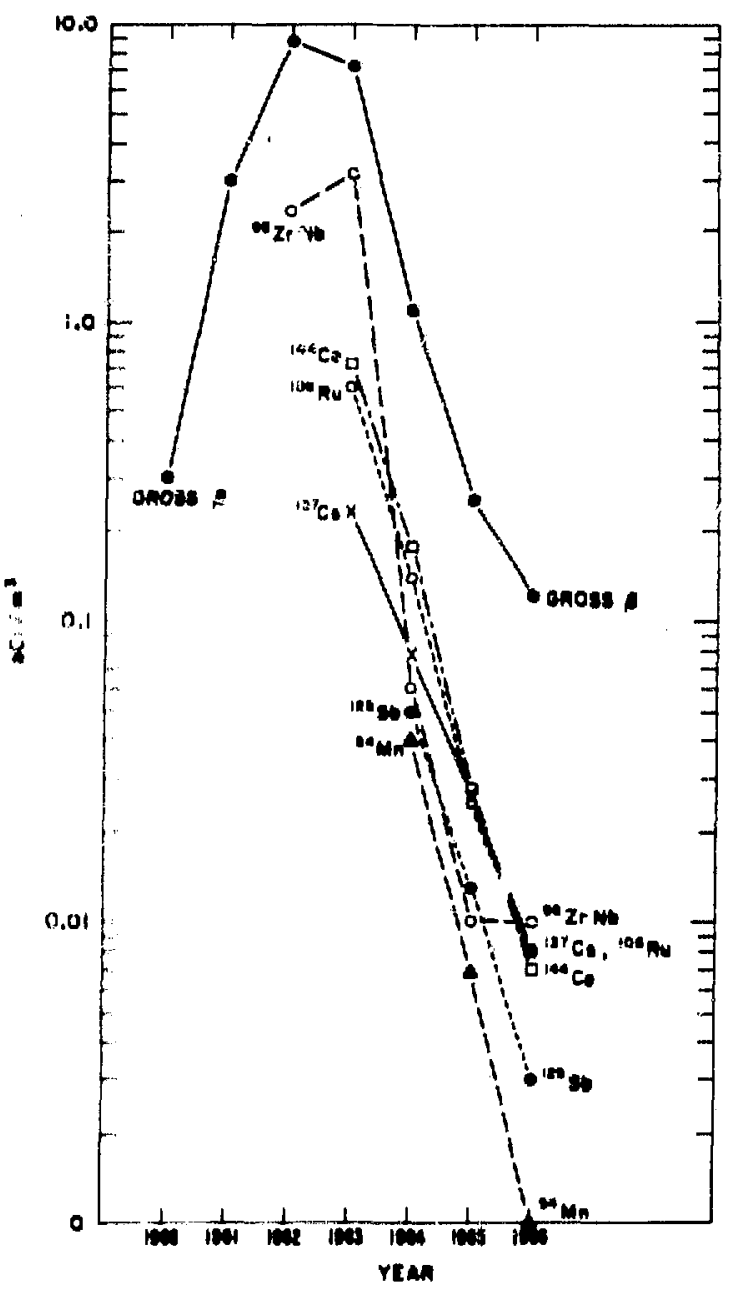

Figure 5. Yearly average ajr particulate concentration, 1960-66.

increass from the preceding background levels were apparent several days earlier. This is presumed to be the result of the gradual sifting down to ground level of material from the high-level clouds of weapons test debris, which appear to move from west to east several days earlier than the bulk of the material in the ground-level cloud.

Yearly average grom $\beta$ air particulate concentrations since $1960,{ }^{95} \mathrm{Zr}$-95 $\mathrm{Nb}$ concentrations since 1962 , and those of other identifiable long-lived $\gamma$ emitters since 1963 are shown in Figure 5. Since there was no significant input from these longlived nuclides after 1962, the rate of decrease of tropospheric concentrations would appear to reflect that of the stratospheric reservoir (assuming a constant fractional rate of the stratospheric to tropospheric transport per year). The mean strato- 


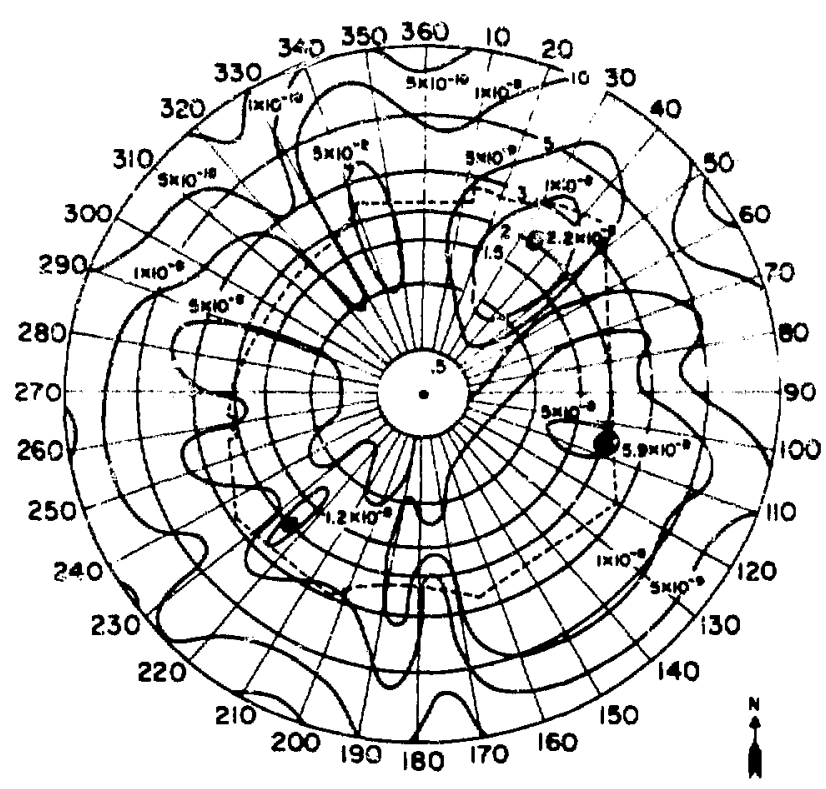

Figure 6. Average ground-level concentrations in unitu/ $\mathrm{m}^{3}$ for stack emission of 1 unit/sec, Season I (J in.-Mar.).

spheric residence time suggested by the nearly exponential decrease of most nuclides between 1963 and 1966 is of the order of $1 \mathrm{yr}$. This is somewhat shorter than most of the estimates based on stratospheric sampling reported by Machta. 16

Three 1-day sumples were obtained in September and October when the dose-rate recorder at a field station indicated that unusually high radiation levels associated with reactor-plume ${ }^{11} \mathrm{Ar}$ had persisted at a location for several hours on the preceding day. The samples were analyzed within $24 \mathrm{hr}$ for ${ }^{82} \mathrm{Br}$ and ${ }^{133} \mathrm{I}$, and 24 -hr average concentrations of the order of $5 \times 10^{-14} \mu \mathrm{Ci} / \mathrm{cm}^{3}$ were established for both isotopes in each sample. The calculated-to-obererved ration of 131 I and ${ }^{133}$ I were almost identical (0.24 and 0.26). Although the higher concentration of ${ }^{131} \mathrm{I}$ and ${ }^{82} \mathrm{Br}$ afford increased sensitivity, the neceacity for frequent sampling and prompt analyais limits the practicability of this method for routine ground-level monitoring of stack effluents.

As indicated above, a charcoal canister for ${ }^{131}$ I sampling was operated in sequence after the particulate filter in each of the continuous highvolume samplen for the same 2-wk sampling period as the particulate filter. After a delay of 2 or 3 days following the sampling period (to allow for the decay of radon and thoron progeny) a com- plete $y$ upectrum firom $(0.1$ to $3.0 \mathrm{MeV}$ ) was made for both filtern.

At the BGRR-HFBR stack, about $1 \%$ of the emitted radioiodine has 1 , en found to be filterable on a 2-day particulate whmple. Stack-emitted 131 I has not been found on routine field air particulate filtern. The interforence from other nuclidew normally preaent on air particulate samples imponed a lower thinit of detection of particulate 131 I of about $0.003 \mathrm{pCi} / \mathrm{m}^{3}$, and it has been arumed on the barie of the stack sampling that all the atack-emitted 1311 pawed through the particulate filter and was collected on the charcoal caninter.

Interference from photopeaks of ${ }^{214} \mathrm{Bi}(\mathrm{RaC})$ originating from radium in the filter medium imposes a lower limit of ensitivity on y analynis for 131. This effect is minimized by using petroleumbased charcoal, loaded into locally fabricated canisters. In the routine analyaix procedure, an initial 5-hr net spectrum of the chrrcoal sample was cbtained. The sample was set aside for about $1 \mathrm{mo}$ and then recounted. The net difference in the $0.36-\mathrm{MeV}$ photopeak region was interpreted as the amount of filtered ${ }^{131}$ I that had decayed during the 1-mo interval.

As shown in Table 3, sampling devices operated by the BNL Health Phyrica Divinion indicated that a total of $2.47 \mathrm{Ci}$ of ${ }^{131}$ I was emitted from

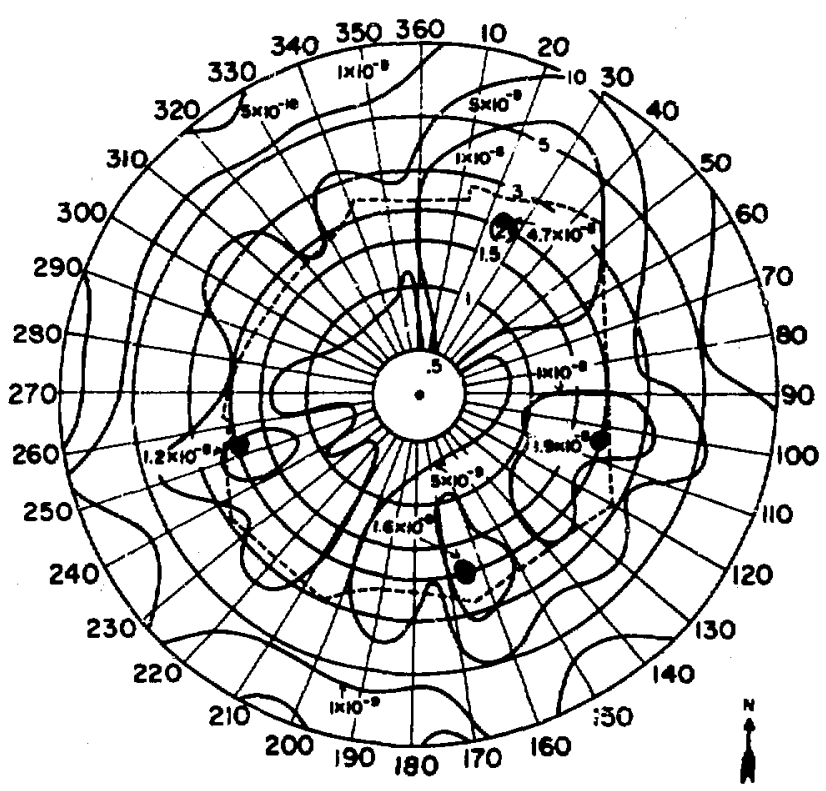

Figure 7. Average ground-level concentrations in units $/ \mathrm{m}^{3}$ for stack emiarion of 1 unit/sec, Season II (May.-Sept.). 
the BGRR-HFBR stack during 1966 in an average concentration of $9.23 \times 10^{-10} \mu \mathrm{Ci} / \mathrm{cm}^{3}$. $\mathrm{Cal}-$ culated ground-level isoconcentration, based on a stack emision rate of 1 unit/sec, for each of four beal seawons (of relatively uniform wind and stability conditions) are shown in Figures 6 to 9. These are revised from similar figures published previously, 4 in the light of increases in effective stack height suggested by a study 17 of the 1965 ANL 131 I environmental monitoring data.

The BGRR-HFBR stack emimion data for each of these seavons are shown in Table 11. Calculated and measured ground-level concentrations of stackeffluent ${ }^{131}$ I for each season are shown in Table 12. The former are derived by applying the reported seasonal stack emission rate of ${ }^{131}$ I to the applicable plotted isoconcentrations (Figures 6 to 9).

The calculated ground-level concentrations are consistently low, especially for sampling locations close to the stack ( $\approx 0.5 \mathrm{~km}$ ). This is probably related to an overestimate of effective stack height. It appears that the formula utilized, which is one recommended for general use by Briggs, ${ }^{18}$ may overpredict plume rise for relatively cool stack effluents such as that of the BGRR-HFBR.

Although the average yearly emission rate of 131I was close to $0.1 \mu \mathrm{Ci} / \mathrm{sec}$, it was several times

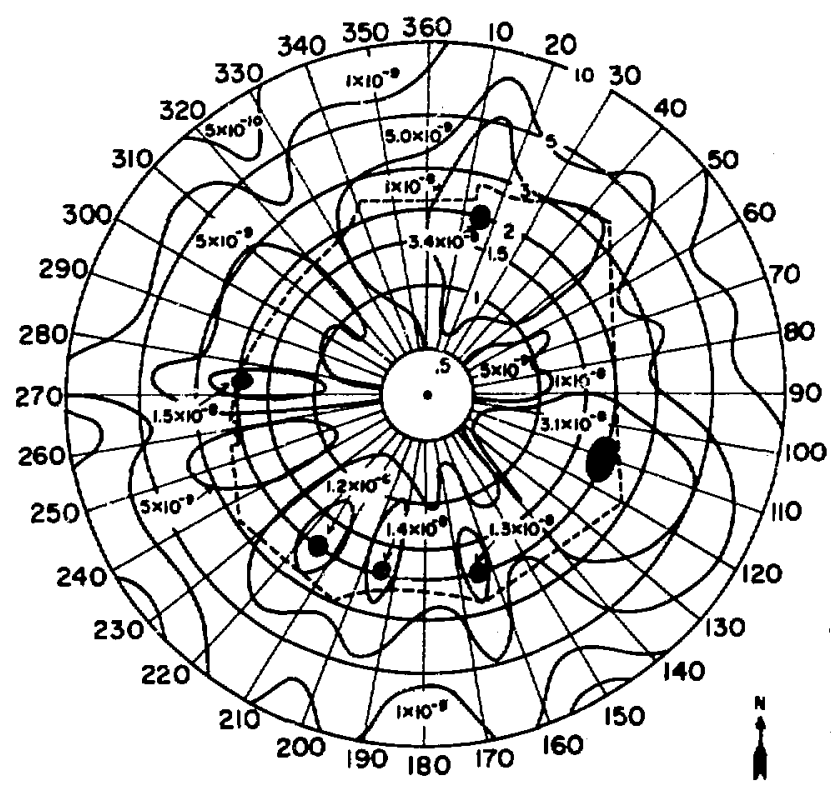

Figure 8. Average ground-level concentration in units $/ \mathrm{m}^{3}$ for stack emission of 1 unit/sec, Season III (Apr. +Oct.). greater during March and April because of unusual releases from the Hot Laboratory off-gas system. These were terminated by the installation of a charcoal filter on Apr. 22. The rates of emission and the peak 2-wk ground-level concentrations of 131I obwerved on site and at the perimeter are shown in Table 13. The average calculated concentration at the eight operating ground-level sampling stations was in good agreement (1.24, S.D. $=0.42$ ) with the obmerved concentrations.

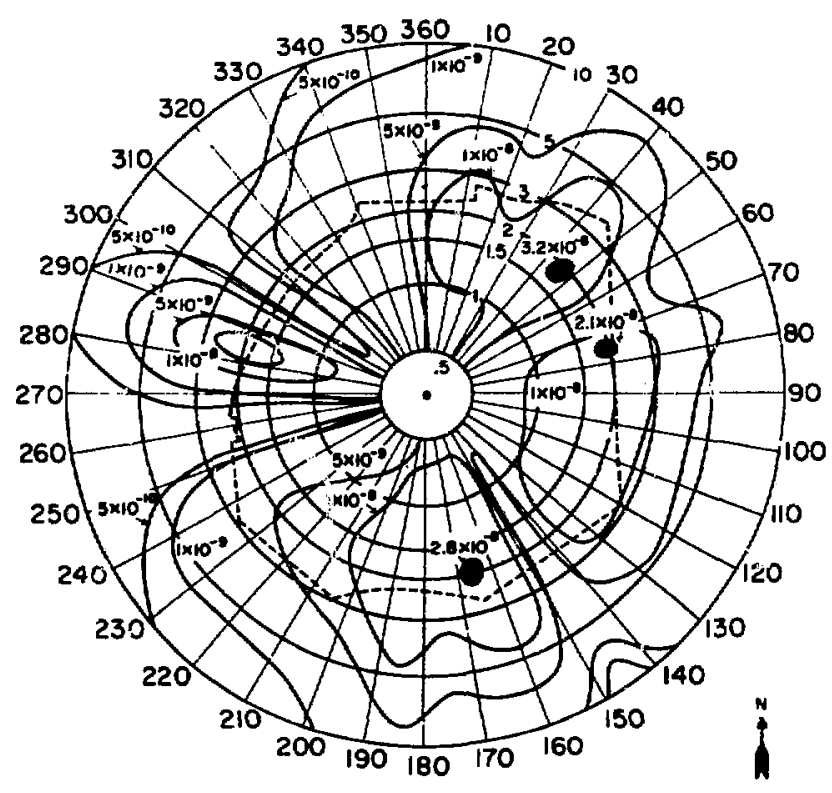

Figure 9. Average ground-Jevel concentrations in units $/ \mathrm{m}^{3}$ for stack emiaion of 1 unit/sec, Season IV (Nov.-Dec.).

Table 11

1966 BNL Environmental Monitoring Seasonal Emision of 131I from BGRR-HFBR Stack

\begin{tabular}{lccc}
\hline Season & $\begin{array}{c}\text { Amount, } \\
\mathrm{mCi}\end{array}$ & $\begin{array}{c}\text { Av conc., } \\
\mathrm{nCi} / \mathrm{cm}^{3}\end{array}$ & $\begin{array}{c}\text { Av release } \\
\text { rate, } \\
\mu \mathrm{Ci} / \mathbf{s c c}\end{array}$ \\
\hline I (Jan.-Mar.) & 880 & 1.35 & 0.113 \\
II (May-Sept.) & 579 & 0.52 & 0.044 \\
III (Apr. +Oct.) & 868 & 2.11 & 0.165 \\
IV (Nov.-Dec.) & 144 & 0.46 & 0.027 \\
Yearly total & 2471 & & \\
Yearly av & & 0.99 & 0.078 \\
\hline
\end{tabular}

"Sum of BGRR-HFBR and Hot Laboratory releases. 
Table 12

1966 BNL Environmental Monitoring

Gaound Level Concentrations of Stack Effluent ${ }^{131} \mathrm{I}, \mathrm{pCi} / \mathrm{m}^{3}$

\begin{tabular}{|c|c|c|c|c|c|c|c|c|c|c|c|c|c|c|c|c|}
\hline \multirow{2}{*}{$\begin{array}{l}\text { Sta- } \\
\text { tion }\end{array}$} & \multicolumn{2}{|c|}{$\begin{array}{l}\text { Downwind } \\
\text { from stack }\end{array}$} & \multicolumn{3}{|c|}{$\begin{array}{c}\text { Season I } \\
\text { (Jan.-Mar.) }\end{array}$} & \multicolumn{3}{|c|}{$\begin{array}{c}\text { Season II } \\
\text { (May-Sept.) }\end{array}$} & \multicolumn{3}{|c|}{$\begin{array}{c}\text { Season III } \\
\text { (Apr. + Oct.) }\end{array}$} & \multicolumn{3}{|c|}{$\begin{array}{l}\text { Season IV } \\
\text { (Nov.-Dec.) }\end{array}$} & \multicolumn{2}{|c|}{ Annual av } \\
\hline & Direction & Distance, $m$ & Calc. & Obs. & $\mathrm{C} / \mathrm{O}$ & Calc. & Obs. & $\mathrm{C} / \mathrm{O}$ & Calc. & Obs. & $\mathrm{C} / \mathrm{O}$ & Calc. & Obs. & $\mathrm{C} / \mathrm{O}$ & Calc. & Oba. \\
\hline $\begin{array}{l}P-2^{2} \\
P-2^{b}\end{array}$ & $\begin{array}{l}130^{\circ} \\
167^{\circ}\end{array}$ & $\begin{array}{l}1850 \\
2160\end{array}$ & 0.0003 & 0.0013 & 0.23 & 0.0002 & 0.0011 & 0.18 & 0.0008 & 0.0016 & 0.50 & 0.0001 & 0.0005 & 0.20 & 0.0005 & 0.0011 \\
\hline P-4 & $63^{\circ}$ & 2200 & 0.0007 & 0.0018 & 0.39 & 0.0004 & 0.0005 & 0.80 & 0.0008 & 0.0020 & 0.40 & 0.0001 & 0.0005 & 0.20 & 0.0005 & 0.0011 \\
\hline S-11 & $300^{\circ}$ & 5810 & 0.0011 & 0.0078 & 0.14 & - & - & - & 0.0017 & 0.0074 & 0.23 & 0.0003 & 0.0008 & 0.40 & $0.0010^{\circ}$ & $0.0057^{e}$ \\
\hline S-6 & $300^{\circ}$ & 14490 & 0.0051 & 0.0067 & 0.76 & - & - & - & 0.0045 & 0.0037 & 1.22 & 0.0004 & 0.0008 & 0.50 & $0.0036^{e}$ & $0.0042^{\circ}$ \\
\hline P.7 & $300^{\circ}$ & 28560 & 0.0034 & 0.0035 & 0.97 & 0.0003 & 0.0012 & 0.25 & 0.0041 & 0.0020 & 0.20 & 0.0003 & 0.0005 & 0.60 & 0.0010 & 0.0018 \\
\hline S-12 & $218^{\circ}$ & 570 & - & - & - & 0.0005 & 0.0020 & 0.25 & 0.0012 & 0.0048 & 0.25 & - & - & - & $0.0007^{c}$ & $0.0028^{e}$ \\
\hline S-13 & $217^{\circ}$ & 1330 & - & - & - & 0.0018 & 0.0047 & 0.38 & 0.0033 & 0.0064 & 0.52 & 0.0007 & 0.0027 & 0.26 & $0.0019 d$ & 0.00464 \\
\hline P-9 & $217^{\circ}$ & 2750 & 0.0017 & 0.0058 & 0.29 & 0.0016 & 0.0045 & 0.35 & 0.0025 & 0.0028 & 0.90 & 0.0005 & 0.0024 & 0.21 & 0.0018 & 0.0042 \\
\hline $0-5$ & $217^{\circ}$ & 6100 & - & - & - & 0.0005 & 0.0030 & 0.17 & - & - & - & - & - & - & $0.0005^{\circ}$ & $0.0030^{\circ}$ \\
\hline & Av & & & & 0.46 & & & 0.34 & & & 0.53 & & & 0.34 & & \\
\hline
\end{tabular}

At Sally Lane.

bAt FAA Tower.

cAv, 7 mo.

dAv, 9 mo.

$\bullet A v$,

Estimated error of observed concentrations: 0.0001 to $0.0005, \pm 100 \% ; 0.0005$ to $0.0025, \pm 50 \% ;>0.0025, \pm 25 \%$.

Air concentrations at the perimeter during this period averaged $1 / 10,000$ of the Radiation Protection Standard ${ }^{8}$ of $1 \times 10^{-10} \mu \mathrm{Ci} / \mathrm{cm}^{3}$. This standard is based on direct inhalation, and the perimeter air concentrations were $1 / 40$ of a calculated acceptable concentration based on deposition and the resultant ${ }^{131}$ I concentration in milk of a hypothetical cow pastured at the perimeter. (The near-

Table 13

1966 BNL Environmental Monitoring BGRR-HFBR Stack Releave of 1311, Mar. 4-Apr. 22

\begin{tabular}{|c|c|c|c|c|c|}
\hline \multirow{3}{*}{$\begin{array}{l}\text { Sampling } \\
\text { period }\end{array}$} & \multirow{3}{*}{$\begin{array}{c}\text { Emission } \\
\text { rate; } \\
\mu \mathrm{Ci} / \mathrm{sec}\end{array}$} & \multicolumn{4}{|c|}{ Peak concentration } \\
\hline & & \multicolumn{2}{|c|}{ On site } & \multicolumn{2}{|c|}{ Perimeter } \\
\hline & & Station & $\mathrm{pCi} / \mathrm{m}^{3}$ & Station & $\mathbf{p C i} / \mathbf{m}^{3}$ \\
\hline $\begin{array}{l}\text { Mar. 4-18 } \\
\text { Mar. 18- }\end{array}$ & 0.26 & S-11 & 0.010 & P-9 & 0.005 \\
\hline Apr. 1 & 0.25 & S-11 & 0.014 & P $\cdots 9$ & 0.011 \\
\hline Apr. 1-15 & 0.39 & S-11 & 0.007 & P-4 & 0.010 \\
\hline Apr. 15-22 & 0.51 & S-13 & 0.022 & P.9 & 0.010 \\
\hline Overall av & v 0.33 & & 0.012 & & 0.09 \\
\hline
\end{tabular}

Estimated error: stack emisaion, $\pm-10 \%$; fielci 131 I concentrations, $\pm 15 \%$. est actual milk cows are 8 to $10 \mathrm{~km}$ from the BGRR-HFBR stack.)

A nonroutine change of air particulate and charcoal filter samples was made on Apr. 22 because of the unusually high stack concentrations of 131 I during the immediately preceding week. From Apr. 15 to 22 a total of $261.8 \mathrm{mCi}$ of ${ }^{131} \mathrm{I}$ was released. The ground-level air particulate samples, as well as the charcoal filter, were recounted at the end of a month's storage in order to evaluate this ${ }^{131}$ I component as accurately as powible. The average diatribution of activity for all eight monitoring stations was $12 \%$ for particulate samples and $88 \%$ for charcoal filters. Although the value for the particulate ample was somewhat greater than anticipated from previous studies, it would seem that the error introduced by the routine procedure of neglecting the particulate fraction at lower overal' concentrations (at which ic could not be evaluated) has not been significant.

\section{micimamow cousction}

Two pot-type rain collector, each with a surface area of $0.33 \mathrm{~m}^{2}$, are situated adjacent to the Meteorology Building, $1300 \mathrm{~m}$ and $90^{\circ}$ downwind from the BGRR-HFBR stack. Two routine collections were made. A sample from one col- 
Table 12

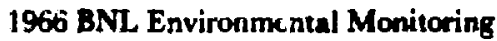

Ground Level Concertration of Stack Efluent ${ }^{131} \mathrm{I}, \mathrm{pC} / \mathrm{m}^{*}$

\begin{tabular}{|c|c|c|c|c|c|c|c|c|c|c|c|c|c|c|c|}
\hline \multirow{2}{*}{$\begin{array}{l}\text { I } \\
\text { nce, } m\end{array}$} & \multicolumn{3}{|c|}{$\begin{array}{c}\text { Seamon I } \\
\text { (Jan-Mar.) }\end{array}$} & \multicolumn{3}{|c|}{$\begin{array}{c}\text { Season II } \\
\text { (May-Sept.) }\end{array}$} & \multicolumn{3}{|c|}{$\begin{array}{c}\text { Seawon IIl } \\
\text { (Apr. + Oct.) }\end{array}$} & \multicolumn{3}{|c|}{$\begin{array}{c}\text { Seswon IV } \\
\text { (Nov,-Dec.) }\end{array}$} & \multicolumn{3}{|c|}{ Annual av } \\
\hline & Calc. & Obs. & $\mathrm{C} / \mathrm{O}$ & Calc. & Oin. & $\mathrm{C} / \mathrm{O}$ & Calc. & Obu. & $\mathrm{c} / \mathrm{O}$ & Calc. & Obu. & $\mathrm{C} / \mathrm{O}$ & Calc. & Obs. & $\mathrm{C} / \mathrm{O}$ \\
\hline $\begin{array}{l}350 \\
160\end{array}$ & 0.0003 & 0.0013 & 0.23 & 0.0902 & 0.0011 & 0.18 & 0.0008 & 0.0016 & 0.50 & 0.0001 & 0.0005 & 0.20 & 0.0005 & 0.0011 & 0.46 \\
\hline 900 & 0.0007 & 0.0018 & 0.39 & 0.0004 & 0.0005 & 0.80 & 0.0058 & 0.0020 & 0.40 & 0.0001 & 0.0005 & 0.20 & 0.0005 & 0.0011 & 0.46 \\
\hline 180 & 0.0011 & 0.0078 & 0.14 & - & - & - & 0.0017 & 0.0074 & 0.23 & 0.0003 & 0.0008 & 0.40 & $0.0010^{c}$ & $0.0057^{c}$ & $0.18^{\circ}$ \\
\hline 90 & 0.0051 & 0.0067 & 0.76 & - & - & - & 0.0045 & 0.0037 & 1.22 & 0.0004 & 0.0008 & 0.50 & $0.0036^{c}$ & $0.0042^{c}$ & $0.86^{\mathrm{c}}$ \\
\hline 160 & 0.0034 & 0.0035 & 0.97 & 0.0003 & 0.0012 & 0.25 & 0.0041 & 0.0020 & $0.24^{\prime \prime}$ & 0.0003 & 0.0005 & 0.60 & 0.0010 & 0.0018 & 0.56 \\
\hline 70 & - & - & - & 0.0005 & 0.0020 & 0.25 & $0.1 \times 012$ & 0.0048 & 0.25 & - & - & - & $0.0007 \mathrm{c}$ & $0.0028^{c}$ & $0.25 \mathrm{c}$ \\
\hline 130 & - & - & - & 0.0018 & 0.0047 & 0.38 & 0.0033 & 0.0064 & 0.52 & 0.0007 & 0.0027 & 0.26 & $0.0019 d$ & 0.0046 & 0.41 \\
\hline 50 & 0.0017 & 0.0058 & 0.29 & 0.0016 & 0.0045 & 0.35 & 0.0025 & 0.0028 & 1.90 & 0.0005 & 0.0024 & 0.21 & 0.0018 & 0.0042 & 0.43 \\
\hline \multirow[t]{2}{*}{$\mathbf{\infty}$} & - & - & - & 0.0005 & 0.0030 & 0.17 & - & - & - & - & - & - & $0.0005^{\circ}$ & $0.0030^{\mathrm{s}}$ & 0.17 \\
\hline & & & 0.46 & & & 0.34 & & & 0.53 & & & 0.34 & & & 0.44 \\
\hline
\end{tabular}

-At FAA Tower.

cAv, 7 mo.

Av, 9 mo.

Av, 5 mo.

nerved concentrations: 0.0001 to $0.0005, \pm 100 \% ; 0.0005$ to $0.0025, \pm 50 \% ;>0.0025, \pm 25 \%$.

incentrations at the perimeter during this iveraged $1 / 10,000$ of the Radiation Protecndard ${ }^{\mathrm{s}}$ of $1 \times 10^{-10} \mu \mathrm{Ci} / \mathrm{cm}^{3}$. This stanased on direct inhalation, and the perimconcentration: were $1 / 40$ of a calculated sle concentration based on depcaition and tant ${ }^{131}$ I concentration in milk of a hypocow pastured at the perimeter. (The near-

\section{Table $\$ 3$}

1966 BNL Environmental Monitoring -HFBR Stack Relence of ${ }^{231}$ I, Mar. 4-Apr. 22

\begin{tabular}{|c|c|c|c|c|c|}
\hline \multirow{3}{*}{\multicolumn{2}{|c|}{$\begin{array}{c}\text { Emimion } \\
\text { rate, } \\
\mu \mathrm{Ci} / \text { sec }\end{array}$}} & \multicolumn{4}{|c|}{ Peak concentration } \\
\hline & & \multicolumn{2}{|c|}{ On site } & \multicolumn{2}{|c|}{ Perimseter } \\
\hline & & Sta son & $\mathrm{pCi} / \mathrm{m}^{3}$ & Station & $\mathbf{p C i} / \mathrm{m}^{\mathrm{a}}$ \\
\hline & 0.26 & S-11 & 0.010 & P.9 & 0.005 \\
\hline & $\begin{array}{l}0.25 \\
0.39\end{array}$ & $\begin{array}{l}S-11 \\
S-11\end{array}$ & $\begin{array}{l}0.014 \\
0.007\end{array}$ & $\begin{array}{l}\text { P-9 } \\
\text { P-4 }\end{array}$ & $\begin{array}{l}0.011 \\
0.010\end{array}$ \\
\hline 2 & 0.51 & S-13 & 0.022 & P.9 & 0.010 \\
\hline 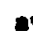 & 0.33 & & 0.012 & & 0.09 \\
\hline
\end{tabular}

ed error: rack eminion, $\pm 10 \%$;

field $131 !$ concentrations, $\pm 15 \%$. est actual milk cows are 8 to $10 \mathrm{~km}$ from the BGRR-HFBR atack.)

A nonroutine change of air particulate and charcoal filter samples was made on Apr. 22 because of the unusually high atack concentrations of ${ }^{131}$ I during the immediately preceding week. From Apr. 15 to 22 a total of $261.8 \mathrm{mCi}$ of $131 \mathrm{I}$ was released. The ground-level air particulate eamples, as well as the charcoal filters, were recounted at the end of a month's storage in order to evaluate this 131I component as accurately as pomible. The average distribution of activity for all eight monitoring stations was 12\% for particulate samples and $88 \%$ for charcoal filters. Although the value for the particulate sample was somewhat greater than anticipated from previous studies, it would rerm that the error introduced by the routine procedure of neglecting the particulate fraction at lower overall concentrations (at which it could not be evaluated) has not been significant.

\section{Precminanow counction}

Two pot-type rain collectors, each with a surface area of $0.33 \mathrm{~m}^{2}$, are situated adjacent to the Meteorology Building, $1300 \mathrm{~m}$ and $90^{\circ}$ downwind from the BGRR-HFBR ateck. Two routine collections were made. A sample from one col-

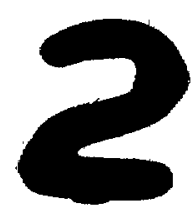


lector was picked up at $\mathbf{0 9 0 0}$ only if precipitation had been oberved during the previous $24 \mathrm{hr}$ (or weekend); the other was picked up ear $\Omega$ Monday morning, whether or not precipitation had occurred. A standard amount of distilled water was used to wash down the collector if no precipitzion was falling at the time the sample was terminated.

Part of each collection was evaporated for gross $\beta$ counting. The largest aingle rainout, $22.3 \mathrm{nCi} / \mathrm{m}^{2}$ at a concentration of $3560 \mathrm{pCi} /$ liter, occurred on Nov. 6, ten days after the second Chinese weapons test during 1966. The second largest, $19.9 \mathrm{nCi} / \mathrm{m}^{2}$ in a concentration of $543 \mathrm{pCi} /$ liter, occurred on May 19, ten days after the first 1966 Chinese test. Weekly samples were analyzed for identifiable $\gamma$-emitting isotopes, and monthly composite samples for ${ }^{89} \mathrm{Sr}$ and ${ }^{90} \mathrm{Sr}$. The monthly averages for gross $\beta$ activity and for individual isotopes in precipitation are given in Table 14. The monthly amounts of gross $\beta$ activity and of the more prevaient isotopes are plotted in Figure 10. The increased gross $\boldsymbol{\beta}$ activity and the presence of fresh fission isotopes in the May, June, and July and again in the November and December samples appear to reflect the contributions from the Chinese tests.

The deposited gross $\beta$ activity after each of the 1966 Chinese tests was several times greater than that collected at BNL shortly after the first (Oct. 1964) and second (May 1965) tests. The locally collected amounts were in general agreement with those reported by Rechen ${ }^{14}$ for Public Health Service stations in northeastern U.S. As indicated previously, there was no perceptible increase in backgrounds attributable to deposition from either 1966 test.

Although the total amount of deposited gross $\beta$ activity was comparable with that collected in 1965 , the amounts of intermediate half-life nuclides such as 285 -day ${ }^{144} \mathrm{Ce}$ and 1 -yr ${ }^{106} \mathrm{Ru}$ were $<1 / 2$ of those observed in 1965 , and the amounts of long-lived nuclides such as $28-y r{ }^{90} \mathrm{Sr}$ and $30-y r{ }^{137} \mathrm{Cs}$ were $\approx^{1 / 2}$ of those observed in that year. This is consistent with the previously indicated 1-yr stratospheric residence time for highlevel weapons-test debris and suggests that the Chinese tests to date have added very little to the

Table 14

1966 BNL Environmental Monitoring

Monthly Average Gross $\beta$ Concentrations, Total Gross $\beta$ Activity, and Principal Isotope Activities in Precipitation

\begin{tabular}{|c|c|c|c|c|c|c|c|c|c|c|c|c|c|c|c|}
\hline \multirow[b]{2}{*}{ Month } & \multirow[b]{2}{*}{$\begin{array}{l}\text { Amount, } \\
\text { in. }\end{array}$} & \multirow{2}{*}{$\begin{array}{c}\text { Grow } \beta \\
\text { conc., } \\
\text { pCi/liter }\end{array}$} & \multirow{2}{*}{$\begin{array}{r}\text { Gross } \beta \\
\text { activity, } \\
\mathrm{nCi} / \mathrm{m}^{2}\end{array}$} & \multicolumn{12}{|c|}{ Isotope activity, $\mathrm{nCi} / \mathrm{m}^{2}$} \\
\hline & & & & $\mathbf{T}_{\mathbf{B e}}$ & ${ }^{54} \mathbf{M n}$ & $89 \mathrm{Sr}$ & $80 \mathrm{Sr}$ & $\begin{array}{l}95 \mathrm{Zr}- \\
95 \mathrm{Nb}\end{array}$ & ${ }^{103 \mathbf{R u}}$ & ${ }^{106 R \mathbf{R}}$ & 131I & ${ }^{137} \mathrm{Cs}$ & $\begin{array}{l}140 \mathrm{Ba}- \\
140 \mathrm{La}\end{array}$ & ${ }^{141 C e}$ & 144Ce \\
\hline Jan. & 2.05 & 35 & 1.69 & 2.67 & $<0.10$ & $<0.05$ & 0.12 & $<0.10$ & $<0.10$ & 0.58 & $<0.10$ & 0.29 & $<0.10$ & $<0.10$ & 0.85 \\
\hline Feb. & 5.19 & 24 & 3.33 & 6.51 & 0.15 & $<0.05$ & 0.30 & $<0.10$ & $<0.10$ & 0.69 & $<0.10$ & 0.48 & $<0.10$ & $<0.10$ & 0.68 \\
\hline Mar. & 2.14 & 48 & 2.59 & 6.68 & 0.12 & $<0.05$ & 0.32 & $<0.10$ & $<0.10$ & 0.39 & $<0.10$ & 0.32 & $<0.10$ & $<0.10$ & 0.57 \\
\hline Apr. & 1.04 & 71 & 1.96 & 3.28 & $<0.10$ & $<0.05$ & 0.30 & $<0.10$ & $<0.10$ & 0.34 & 0.07 & 0.49 & $<0.10$ & $<0.10$ & 0.35 \\
\hline May & 8.27 & 265 & 34.03 & 22.00 & 0.22 & 0.71 & 0.79 & 5.15 & 2.88 & 1.19 & 3.12 & 1.17 & 8.39 & 2.19 & 1.34 \\
\hline June & 1.04 & 218 & 6.44 & 3.30 & $<0.10$ & 0.20 & 0.10 & 0.13 & 1.27 & 0.28 & $<0.10$ & 0.25 & 1.17 & 0.35 & 0.40 \\
\hline July & 1.13 & 151 & 4.45 & 8.13 & $<0.10$ & 0.21 & 0.19 & 0.60 & 0.86 & 0.56 & $<0.10$ & 0.38 & 0.88 & 0.54 & 0.38 \\
\hline Aug. & 2.83 & 17 & 0.61 & 1.66 & 0.10 & 0.08 & 0.07 & $<0.10$ & $<0.10$ & $<0.10$ & $<0.10$ & 0.21 & $<0.10$ & 0.06 & $<0.10$ \\
\hline Sept. & 4.52 & 19 & 2.13 & 5.68 & $<0.10$ & 0.17 & 0.07 & $<0.10$ & $<0.10$ & 0.92 & $<0.10$ & 0.30 & $<0.10$ & $<0.10$ & 0.54 \\
\hline Oct. & 4.77 & 10 & 1.21 & 3.54 & $<0.10$ & 0.44 & 0.11 & 0.31 & $<0.10$ & 0.67 & $<0.10$ & 0.28 & $<0.10$ & $<0.10$ & 0.34 \\
\hline Nov. & 2.35 & 435 & 26.56 & 1.45 & $<0.10$ & 0.77 & 0.06 & 1.87 & 2.10 & 0.15 & 1.75 & 0.10 & 4.20 & 1.23 & 0.37 \\
\hline Dec. & 3.05 & 39 & 2.27 & 3.38 & $<0.10$ & 0.13 & 0.13 & 0.13 & $<0.10$ & 0.36 & $<0.10$ & 0.26 & 0.17 & 0.17 & 0.35 \\
\hline Total & $\mathbf{3 8 . 3 8}$ & 1332 & 87.27 & 68.28 & - & 2.81 & 2.56 & 8.49 & 7.51 & 6.18 & 5.39 & 4.53 & 15.16 & 4.84 & 6.22 \\
\hline Av & 3.20 & 111 & 7.27 & 5.69 & - & 0.23 & 0.21 & 0.71 & 0.63 & 0.52 & 0.45 & 0.38 & 1.26 & 0.40 & 0.52 \\
\hline \multicolumn{16}{|c|}{ Eetimated error, \% } \\
\hline & \pm 0.10 & \pm 10 & \pm 15 & \pm 25 & \pm 0.10 & $\pm 10^{n}$ & $\pm 10^{a}$ & $\pm 10^{b}$ & $\pm 25^{b}$ & $\pm 15^{b}$ & $\pm 15^{b}$ & $\pm 10^{n}$ & $\pm 25 b$ & $\pm 25^{b}$ & $\pm 15^{b}$ \\
\hline
\end{tabular}




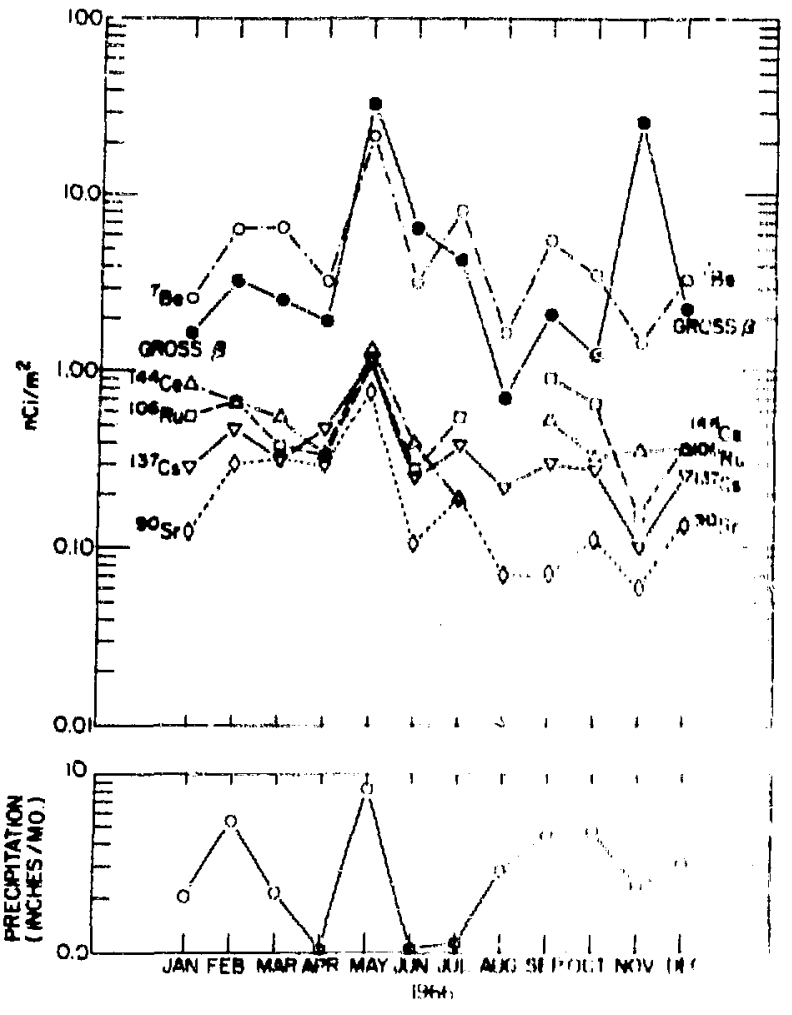

Figure 10. Monthly presipilation vollection, sromm $H$

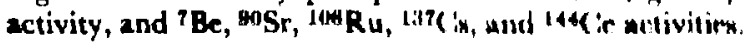

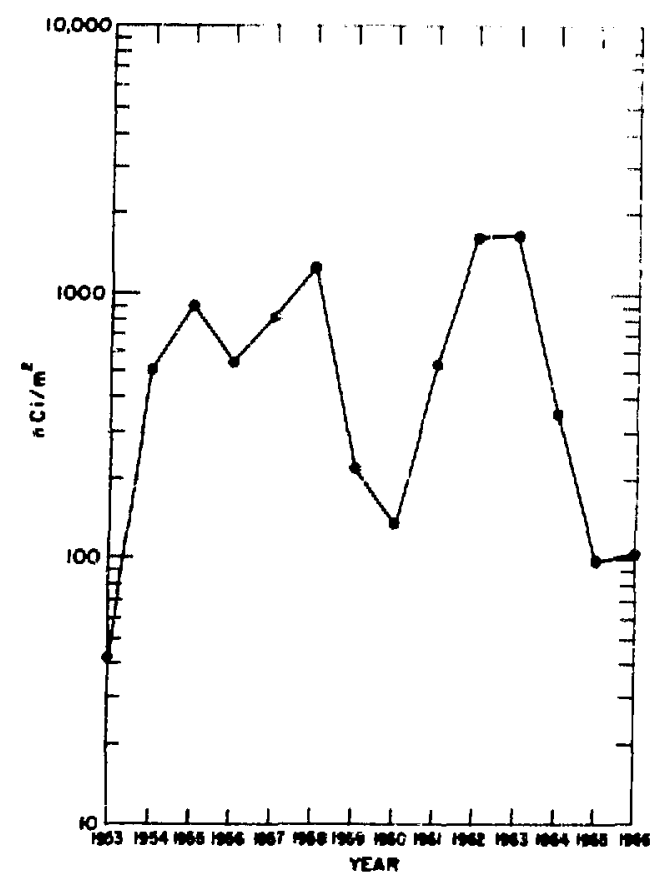

Figure 11. Yearly total grom $\beta$ activity in precipitation, 1953-66.

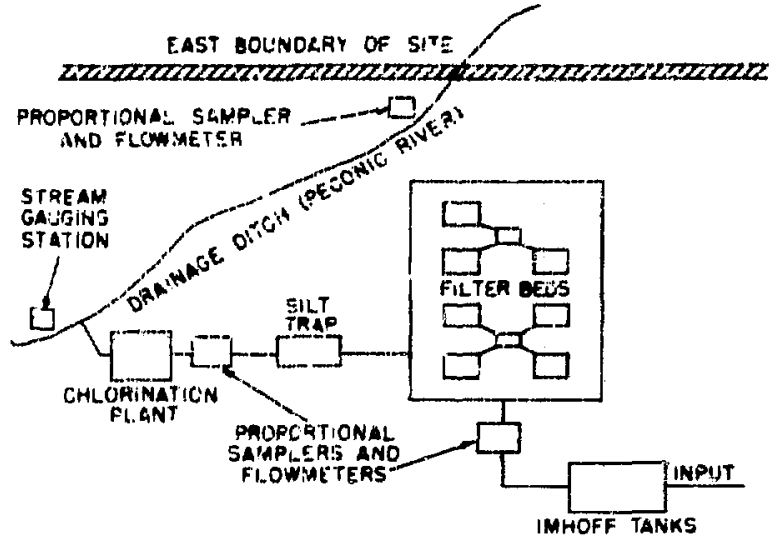

Fiequre 12. BNL sewage proceasing and monitoring system.

uracospheric inventory. The monthly amounts of the bonger lived fallout isotopes, ${ }^{90} \mathrm{Sr},{ }^{137} \mathrm{Cs}$, and $144(i)$, are in general agreement with those reported by the Flealth and Safety Laboraton.18 for Nrow Y'ork Ciry and for Westwood, N.J.

Raill is a settled dust collections have been mucir by the Environmental Monitoring Section at Broskizaven National Laboratory continuously mince the lutter part of 1953. Total yearly activity in nhown in Figure 11. The amount for 1953 is entimated from the Sept.-Dec. average.

\section{Loung crivent monmonse}

Small smounts of low-level radiosctive liquid effluents were routinely dispowed of by release into the Laburatory's sanitary waste system, where they were diluted by a large volume of uncontamjnuted water. This liquid waste effluent passed through an Imhofi tank which removed moat of the solids and then flowed onto sand filter beds, from which inost of it was collected by an underlying tile field. The liquid effluent wan then chlorinated and discharged into a small stream that forms one of the headwaters of the Peconic River.

The monitoring arrangements for the central swage system are indicated in Figure 12. During May a new totalizing flowmeter (Leupold \& Stevens, TF 61-2), which includes provision for actuating a sampler for each 2000 gal of flow, in combination with a poaitive-action batteryoperated sampler (Braiksford DU-1), was instalied at the perimeter sampling station. A proportional sample is obtained through use of an electronic circuit devised by the BNL Inatrumentation Division. The circuit is arranged so that the pump 
Table 15

1966 BNL Environmental Monitoring

Monthly Average Liquid Effluent Flow, Concentration, and Total Gross $\beta$ Activity

\begin{tabular}{|c|c|c|c|c|c|c|c|c|c|}
\hline \multirow[b]{2}{*}{ Month } & \multicolumn{3}{|c|}{ Imhoff tank } & \multicolumn{3}{|c|}{ Chlorine house } & \multicolumn{3}{|c|}{ Perimeter } \\
\hline & $\begin{array}{l}\text { Flow, } \\
\text { gai/day }\end{array}$ & $\begin{array}{l}\text { Cunc., } \\
\text { pCi/liter }\end{array}$ & $\begin{array}{c}\text { Activity, } \\
\text { mCi }\end{array}$ & $\begin{array}{l}\text { Flow, } \\
\text { gal/day }\end{array}$ & $\begin{array}{l}\text { Conc., } \\
\text { pCi/liter }\end{array}$ & $\begin{array}{c}\text { Activity, } \\
\text { mCi }\end{array}$ & $\begin{array}{c}\text { Flow, } \\
\text { gal/day }\end{array}$ & $\begin{array}{l}\text { Conc., } \\
\text { pCi/liter }\end{array}$ & $\begin{array}{c}\text { Activity, } \\
\text { mCi }\end{array}$ \\
\hline Jan. & 732,000 & 54 & 4.7 & 549,000 & 35 & 2.2 & $635,0 \times 0$ & 30 & 2.2 \\
\hline Feb. & 747,000 & 72 & 6.3 & 594,000 & 61 & 4.3 & 741,000 & 49 & 4.3 \\
\hline Mar. & 771,000 & 57 & 4.7 & 595,000 & 46 & 2.9 & 714,000 & 38 & 2.9 \\
\hline Apr. & 951,000 & 21 & 2.4 & 701,000 & 35 & 2.9 & 787,000 & 31 & 2.9 \\
\hline May & $1,084,000$ & 48 & 5.9 & 792,000 & 34 & 3.1 & 850,000 & 32 & 3.1 \\
\hline Junte & $1,232,000$ & 235 & $33.9^{*}$ & 912,000 & 50 & 5.3 & 974,000 & 48 & 5.3 \\
\hline July & $1,273,000$ & 82 & 10.3 & 956,000 & 3 & 4.0 & 875,000 & 41 & 3.8 \\
\hline Aug. & $1,410,000$ & 43 & 7.1 & 943,000 & 31 & 3.8 & 910,000 & 28 & 3.3 \\
\hline Sept. & $1,056,000$ & 24 & 3.0 & 875,000 & 20 & 2.6 & 866,000 & 22 & 2.0 \\
\hline Oct. & $1,060,000$ & 15 & 2.1 & 838,000 & 22 & 2.4 & 825,000 & 21 & 2.3 \\
\hline Nov. & 975,000 & 16 & 1.7 & 755,000 & 27 & 1.9 & 711,000 & 23 & 1.8 \\
\hline Dec. & 904,000 & 31 & 3.2 & 589,000 & 23 & 1.5 & 587,000 & 23 & 1.6 \\
\hline \multicolumn{2}{|l|}{ Total } & & 8.1 & & & 36.9 & & & 35.4 \\
\hline Av & $1,015,000$ & 60 & & 757,000 & 35 & & 800,000 & 32 & \\
\hline \multicolumn{2}{|c|}{ Fstimated error, \% } & \pm 10 & \pm 10 & & \pm 10 & \pm 10 & & \pm 10 & \pm 10 \\
\hline
\end{tabular}

$\approx 20$-mCi release of $87.5-$ day ${ }^{35} \mathrm{~S}+245-$ day ${ }^{65} \mathrm{Zn}$.

makes one full stroke following each 2000-gal signal from the flowmeter, during which it delivers $\approx 10 \mathrm{ml}$.

Values of the monthly average gross $\beta$ concentration and total gross $\beta$ activity for the input to the filter bed, discharge to the river, and at the site boundary are given in Table 15 . The perimeter data prior to May are calculated from the concentrations at the chlorine house adjusted for the increase in flow at the boundary. The May-Dec. sampling results confirm the previous assumption that essentially $100 \%$ of the activity at the chlorine house passes off site at the perimeter. A calculated radiation protection standard concentration of $1070 \mathrm{pCi} /$ liter, based upon an assumed $20 \%{ }^{90} \mathrm{Sr}$ content, is applied at the boundary.

A $\gamma$ spectrum and a ${ }^{90} \mathrm{Sr}$ analysis were performed on a monthly composite of samples taken from the input to the sand filter beds, the effluent from the beds, and at the perimeter (May-Dec.). The amounts and average concentrations of identifiable iwotopes entering and leaving the beds and pasing the perimeter are shown in Table 16. The latter are calculated data from January to April and measured data thereafter.
The amouncs of radioactivity released as liquid waste by the Laboratory have decreased annually during recent years up to 1966. Information from internal BNL reports concerning the gross $\beta$ liquid effluent activity going into and discharged from the sand filter beds since 1951 is presented in Figure 13.

The sand filter beds have been reported to be about $90 \%$ efficient for most isotopes. ${ }^{20} \mathrm{~A}$ recapitulation of the unusual releases involving millicurie amounts of ${ }^{32} \mathrm{P},{ }^{35} \mathrm{~S},{ }^{60} \mathrm{Co},{ }^{65} \mathrm{Zn}$, and ${ }^{131} \mathrm{I}$ that occurred during the year is presented in Table 17. It appears that on a short-term basis all the isotopes involved were substantially retained on the filter beds or lost to groundwater. The excess of ${ }^{90} \mathrm{Sr}$ and ${ }^{137} \mathrm{Cs}$ in the filter bed effluent over the input during recent years, again apparent in 1966 , indicates that these isotopes are not permanently retained in the filter beds. A delay mechanism with a long time constant appears to be operative.

Accumulations of dried sludge previously pumped from the Imhoff tank were disposed of to the BNL dump during January and November. Gross $\alpha$ and grows $\beta$ concentrations, the concentra- 
Table 16

1966 BNL Environmental Monitoring

Total Activities and Average Concentrations of Identifiable Isotopes

\begin{tabular}{|c|c|c|c|c|c|c|c|c|c|c|c|}
\hline Month & Gross $\beta$ & $32 \mathbf{P}$ & ${ }^{60} \mathrm{Co}$ & ${ }^{65} \mathrm{Zn}$ & sosr & 131I & ${ }^{137} \mathrm{Cs}$ & ${ }^{144} \mathrm{Ce}$ & ${ }^{3} \mathbf{H}$ & $35 \mathrm{~S}$ & ${ }^{54} \mathrm{Mn}$ \\
\hline \multicolumn{12}{|c|}{ Imhoff Tank } \\
\hline Jan. & 5.1 & 2.1 & 0.3 & 0.2 & 0.3 & 1.1 & 0.6 & 0.5 & $<0.2 \times 10^{3}$ & $<0.5$ & $<0.1$ \\
\hline Feb. & 5.6 & - & 1.1 & $<0.1$ & 0.3 & 1.8 & 0.3 & 0.2 & $<0.2 \times 10^{3}$ & 2.0 & 0.2 \\
\hline Mar. & 4.9 & - & 0.4 & $<0.1$ & 0.2 & 4.2 & 0.5 & 0.1 & $<0.2 \times 10^{3}$ & $<0.5$ & 0.1 \\
\hline Apr. & 2.1 & - & 0.2 & $<0.1$ & 0.2 & 0.7 & 0.4 & $<0.1$ & $<0.2 \times 10^{3}$ & $<0.5$ & 0.1 \\
\hline May & 9.5 & - & 3.0 & $<0.1$ & 0.5 & 0.6 & 0.9 & $<0.1$ & $<0.2 \times 10^{3}$ & $<0.5$ & $<0.1$ \\
\hline June & 27.5 & - & $<0.1$ & 6.4 & 0.3 & 0.3 & 0.6 & $<0.1$ & $<0.2 \times 10^{3}$ & 20.0 & $<0.1$ \\
\hline July & 10.3 & - & $<0.1$ & 4.9 & 0.3 & $<0.1$ & 0.8 & $<0.1$ & $<0.2 \times 10^{3}$ & $<0.5$ & 0.2 \\
\hline Aug. & 7.1 & - & $<0.1$ & 2.4 & 0.3 & 2.2 & 0.9 & $<0.1$ & $<0.2 \times 10^{3}$ & $<0.5$ & $<0.1$ \\
\hline Sept. & 3.0 & - & 0.3 & 0.7 & 0.2 & 0.5 & 0.5 & $<0.1$ & $<0.2 \times 10^{3}$ & $<0.5$ & $<0.1$ \\
\hline Oct. & 4.4 & - & 0.6 & 0.5 & 0.1 & 0.4 & 0.7 & 0.1 & $1.5 \times 10^{3}$ & $<0.5$ & $<0.1$ \\
\hline Nov. & 2.0 & - & 0.1 & 0.3 & 0.1 & $<0.1$ & 0.6 & $<0.1$ & $0.9 \times 10^{3}$ & $<0.5$ & $<0.1$ \\
\hline Dec. & 3.6 & - & $<0.1$ & 0.4 & 0.2 & 0.3 & 0.9 & $<0.1$ & $1.9 \times 10^{3}$ & $<0.5$ & $<0.1$ \\
\hline Total, mCi* & * 85.1 & - & 6.2 & 16.0 & 3.0 & 12.2 & 7.7 & 1.3 & $5.2 \times 10^{3}$ & 24.5 & 1.0 \\
\hline $\begin{array}{l}\text { Av conc., } \\
\text { pCi liter }\end{array}$ & 60 & - & 4 & 11 & 2 & 8 & 5 & 1 & $3.7 \times 10^{3}$ & 17 & $<1$ \\
\hline \multicolumn{12}{|c|}{ Chlorine House } \\
\hline Jan. & 2.7 & 0.1 & 0.6 & $<0.1$ & 0.4 & 0.4 & 1.8 & 0.4 & $<0.2 \times 10^{3}$ & $<0.5$ & $<0.1$ \\
\hline Feb. & 3.9 & - & 0.9 & $<0.1$ & 0.2 & 0.5 & 1.5 & $<0.1$ & $<0.2 \times 10^{3}$ & $<0.5$ & 0.4 \\
\hline Mar. & 3.0 & - & 0.7 & $<0.1$ & 0.2 & 0.7 & 1.4 & $<0.1$ & $<0.2 \times 10^{3}$ & $<0.5$ & $<0.1$ \\
\hline Apr. & 2.7 & - & 0.7 & $<0.1$ & 0.3 & 0.1 & 1.4 & $<0.1$ & $<0.2 \times 10^{3}$ & $<0.5$ & 0.1 \\
\hline May & 3.6 & - & 0.4 & $<0.1$ & 0.2 & $<0.1$ & 2.0 & $<0.1$ & $<0.2 \times 10^{3}$ & $<0.5$ & $<0.1$ \\
\hline June & 4.7 & - & 0.3 & $<0.1$ & 0.2 & $<0.1$ & 1.6 & $<0.1$ & $<0.2 \times 10^{3}$ & 2.4 & $<0.1$ \\
\hline July & 4.0 & - & 0.2 & 0.1 & 0.8 & $<0.1$ & 1.9 & $<0.1$ & $<0.2 \times 10^{3}$ & $<0.5$ & $<0.1$ \\
\hline Aug. & 3.8 & - & 0.3 & 0.2 & 0.5 & 0.5 & 2.0 & $<0.1$ & $<0.2 \times 10^{3}$ & $<0.5$ & $<0.1$ \\
\hline Sept. & 2.6 & - & $<0.1$ & 0.2 & 0.2 & 0.4 & 1.4 & $<0.1$ & $<0.2 \times 10^{3}$ & $<0.5$ & $<0.1$ \\
\hline Oct. & 2.8 & - & 0.5 & 0.1 & 0.2 & $<0.1$ & 1.5 & 0.1 & $1.2 \times 10^{3}$ & $<0.5$ & $<0.1$ \\
\hline Nov. & 1.9 & - & 0.4 & $<0.1$ & 0.1 & $<0.1$ & 1.6 & $<0.1$ & $0.8 \times 10^{3}$ & $<0.5$ & $<0.1$ \\
\hline Dec. & 1.5 & - & $<0.1$ & $<0.1$ & 0.1 & 0.3 & 0.7 & $<0.1$ & $1.1 \times 10^{3}$ & $<0.5$ & $<0.1$ \\
\hline Total, $\mathrm{mCi}^{*}$ & * 37.2 & - & 5.1 & 1.0 & 3.4 & 3.2 & 18.8 & 1.0 & $4.0 \times 10^{5}$ & 5.2 & 1.0 \\
\hline Av conc., & & & & & & & & & & & \\
\hline pCi/liter & 35 & - & 5 & 1 & 3 & 3 & 18 & 1 & $3.8 \times 10^{3}$ & 5 & $<1$ \\
\hline \multicolumn{12}{|c|}{ Perimeter } \\
\hline Jan.** & 2.7 & & 0.6 & $<0.1$ & 0.4 & 0.4 & 1.8 & 0.4 & $<0.2 \times 10^{3}$ & $<0.5$ & 0.4 \\
\hline Feb. $* *$ & 3.9 & & 0.9 & $<0.1$ & 0.2 & 0.5 & 1.5 & $<0.1$ & $<0.2 \times 10^{3}$ & $<0.5$ & $<0.1$ \\
\hline Mar.** & 3.0 & & 0.7 & $<0.1$ & 0.2 & 0.7 & 1.4 & $<0.1$ & $<0.2 \times 10^{3}$ & $<0.5$ & $<0.1$ \\
\hline Apr.** & 2.7 & & 0.7 & $<0.1$ & 0.3 & 0.1 & 1.4 & $<0.1$ & $<0.2 \times 10^{3}$ & $<0.5$ & $<0.1$ \\
\hline May & 2.1 & & 0.4 & $<0.1$ & 0.1 & $<0.1$ & 1.3 & $<0.1$ & $<0.2 \times 10^{3}$ & 3.2 & $<0.1$ \\
\hline June & 5.6 & & $<0.1$ & $<0.1$ & 0.2 & $<0.2$ & 1.5 & $<0.1$ & $<0.2 \times 10^{3}$ & $<0.5$ & $<0.1$ \\
\hline July & 3.8 & & $<0.1$ & 0.2 & 0.6 & $<0.1$ & 2.0 & $<0.1$ & $<0.2 \times 10^{3}$ & $<0.5$ & $<0.1$ \\
\hline Aug. & 3.3 & & $<0.1$ & $<0.1$ & 0.4 & $<0.1$ & 2.0 & $<0.1$ & $<0.2 \times 10^{3}$ & $<0.5$ & $<0.1$ \\
\hline Sept. & 2.0 & & $<0.1$ & $<0.1$ & 0.3 & 0.5 & 1.4 & $<0.1$ & $<0.2 \times 10^{3}$ & $<0.5$ & $<0.1$ \\
\hline Oci. & 2.3 & & 0.3 & $<0.1$ & 0.2 & $<0.1$ & 1.7 & 0.2 & $1.1 \times 10^{3}$ & $<0.5$ & $<0.1$ \\
\hline Nov. & 1.8 & & 0.3 & $<0.1$ & 0.1 & $<0.1$ & 1.5 & $<0.1$ & $0.6 \times 10^{3}$ & $<0.5$ & $<0.1$ \\
\hline Dec. & 1.6 & & $<0.1$ & $<0.1$ & 0.1 & 0.2 & 0.6 & $<0.1$ & $1.0 \times 10^{3}$ & $<0.5$ & $<0.1$ \\
\hline Total, $\mathrm{mCi}^{*}$ & 34.8 & & 4.2 & 0.8 & 3.1 & 2.8 & 16.4 & 1.1 & $3.5 \times 10^{3}$ & 6.0 & 1.0 \\
\hline $\begin{array}{l}\text { Av conc., } \\
\text { pCi/liter }\end{array}$ & 32 & & 4 & 1 & 3 & 3 & 17 & 1 & $3.2 \times 10^{3}$ & 6 & $<1$ \\
\hline \multicolumn{12}{|l|}{ Eatimated } \\
\hline error, $\%=$ & \pm 10 & & \pm 25 & \pm 25 & \pm 10 & \pm 10 & \pm 10 & \pm 25 & \pm 25 & \pm 25 & \pm 50 \\
\hline
\end{tabular}




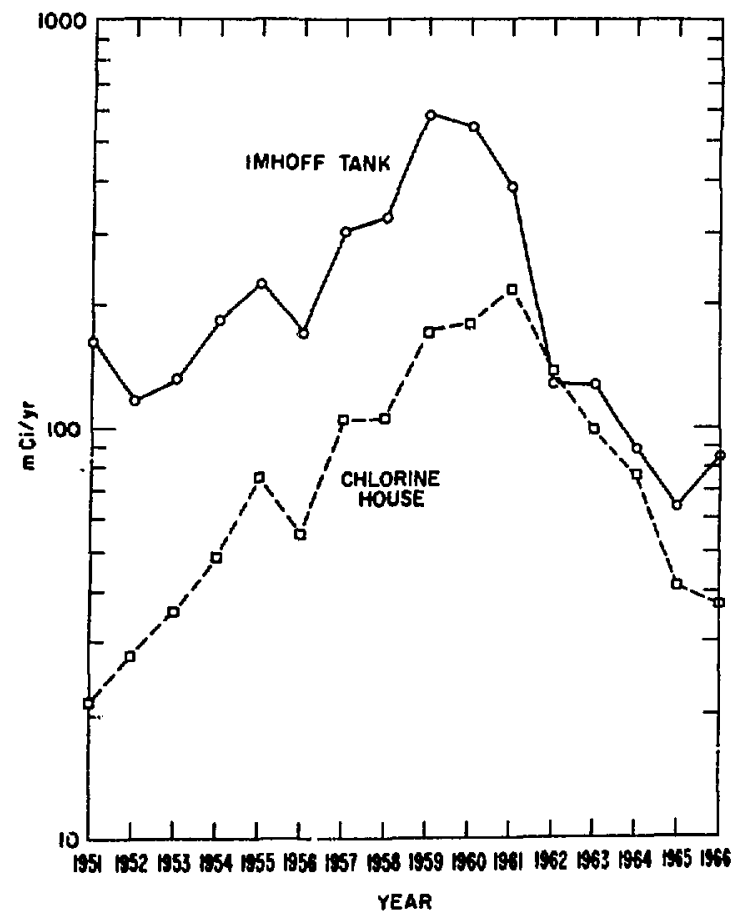

Figure 13. Yearly gross $\beta$ activity in liquid effluent, 1951-66.

tions of the principal nuclides present, their estimated amounts, and the approximate fractions of total input to the Imhoff tank removed by the sludge are shown in Table 18. The total quantity of sludge removed from the drying beds is not well defined. There is also a delay of several months between the time it is pumped from the tank to dry and its removal. The previous removal of sludge from the drying beds was in October 1964. The approximate fractions removed have therefore been based on the assumption that they represent settling in the tank during 1964 and 1965 . With the exception of ${ }^{60} \mathrm{Co}$, it appears that $<25 \%$ of an incoming radionuclide is removed by the sludge. The physical removal of suspended solids in the Imhoff tanl is estimated by the BNL Plant Engineering Division $^{21}$ to be about $50 \%$.

\section{STREAM SAMPLNO}

Monthly "grab" water samples were obtained at on- and off-site locations along the upper tributary of the Peconic River, into which the Laboratory routinely discharges low-level wastes. Reference grab samples were also obtained from other nearby streams and bodies of water outside the
Table 17

1966 BNL Environmental Monitoring Apparent Retention Efficiency of Sand Filter Beds

\begin{tabular}{|c|c|c|c|c|}
\hline Isotope & Date & $\begin{array}{c}\text { Imhoff } \\
\text { tank (in), } \\
\text { mCi }\end{array}$ & $\begin{array}{c}\text { Chlorine } \\
\text { house (out), } \\
\text { mCi }\end{array}$ & $\begin{array}{c}\text { Retention } \\
\text { on filter } \\
\text { beds, \% }\end{array}$ \\
\hline $\begin{array}{l}\text { 32P } \\
35 \mathrm{~S}\end{array}$ & $\begin{array}{l}\text { Dec. } 27 \\
\text { Jan. } 31-\end{array}$ & 2.15 & $0.09^{*}$ & 96 \\
\hline 35S & $\begin{array}{r}\text { Feb. } 6 \\
\text { June } 3-4\end{array}$ & $\underset{20.0}{\approx 2.00}$ & $\begin{array}{c}<0.50 \\
2.4\end{array}$ & $\begin{array}{r}>75 \\
88\end{array}$ \\
\hline${ }^{60} \mathrm{Co}$ & May 23-31 & 2.97 & 0.44 & 85 \\
\hline $65 \mathrm{Zn}$ & June & 6.39 & 0.34 & 95 \\
\hline${ }^{65} Z_{n}$ & July & 4.89 & 0.05 & 99 \\
\hline 131I & Mar. 8-9 & 4.23 & 0.67 & 84 \\
\hline
\end{tabular}

*Estimated from gross $\beta$ concentrations for Dec. 27 and 28 samples.

Laboratory's drainage area. The sampling locations (Figure 14) were as follows.

A. Peconic River at Schultz Rd., 15,900 ft downstream from chlorine house.

B. Peconic River at Wading River-Manorville Rd., 23,100 ft downstream from chlorine house.

C. Peconic River at Manorville, $\approx 35,500 \mathrm{ft}$ downstream from chlorine house.

D. Peconic River at Galverton, $\approx \mathbf{4 6 , 7 0 0} \mathrm{ft}$ downstream from chlorine house.

E. Peconic River, upstream from BNL effluent outfall.

F. Peconic River at north tributary (independent of BNL drainage).

G. Carman's River at Middle island.

H. Carman's River at outflow of Yaphank Lake.

I. Artist Lake (maintained by water table, no surface outflow).

J. Lake Panamoka (maintained by water takle, no surface outflow).

K. Peconic River, just below BNL effluent outfall.

L. Peconic River, 1300 ft below effluent outfall.

M. Peconic River, $2600 \mathrm{ft}$ below BNL effiuent outfall (at BNL boundary).

Q Peconic River, $6900 \mathrm{ft}$ downstream from BNL effluent outfall.

Stream-water ample gross $\beta$ concentrations found during 1966 are summarized in Table 19. To facilitate comparison, the samples are divided into two groups, one comprising locations in sequence 


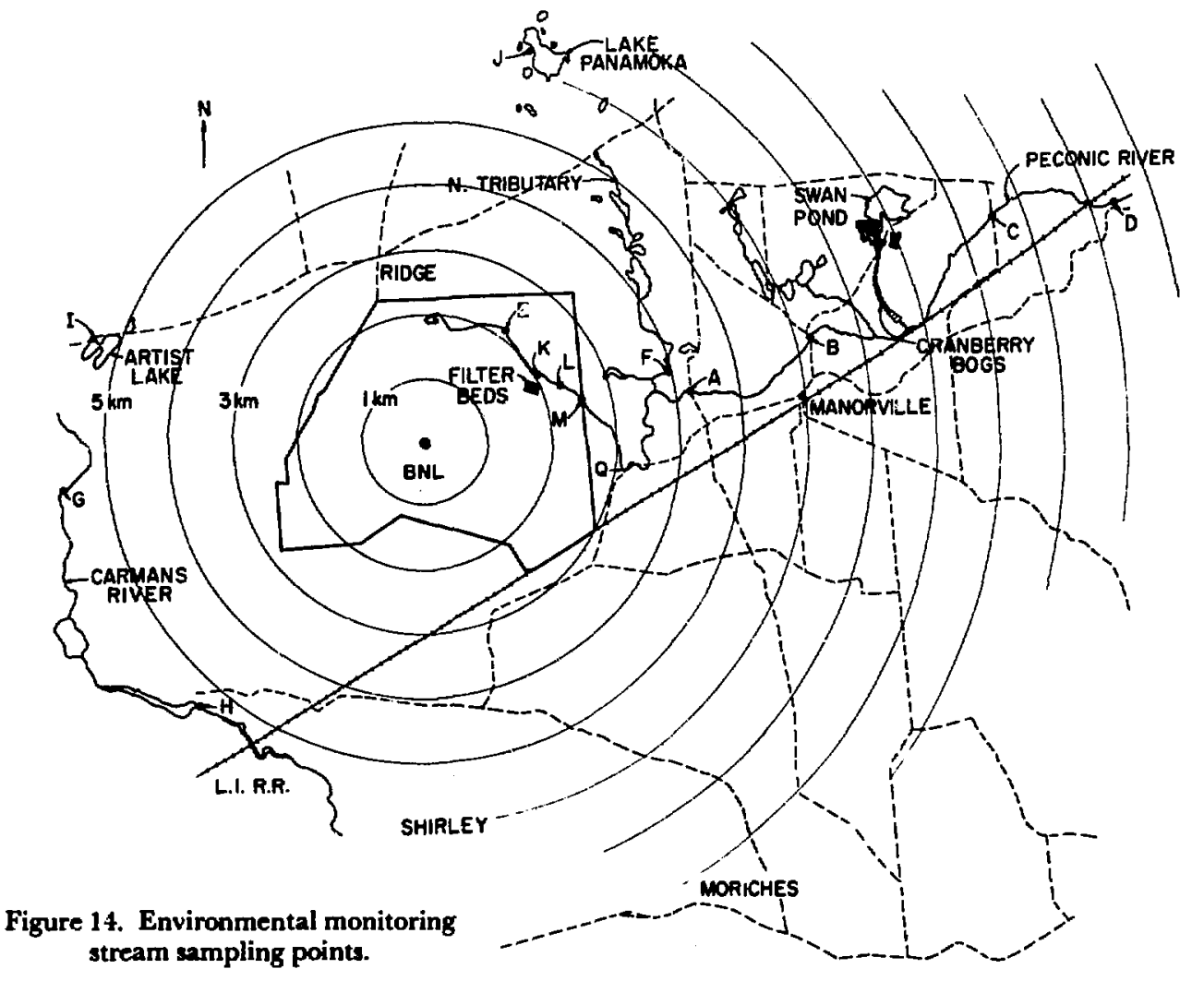

from upstream to downstream on the Peconic, and the other, control locations. Off-site stream sampling was initiated in 1960 . Yearly averages since that time are also given in Table 19. There appears to be relatively little dilution by tributaries in the upper reaches of the strieam. Three separate measurements made by the Water Resources Division of the U.S. Geological Survey ${ }^{22}$ during 1966 indicated that the average daily flow of the Peconic River at Schultz Rd. (sampling location A) was about $11 \%$ of that at the perimeter (sampling location $\mathrm{M}$ ), while continuous flow measurements made at the Riverhead Gauging Station, near the mouth of the river, averaged $1.04 \times 10^{7}$ $\mathrm{gal} /$ day, about 15 times that at the perimeter. The fraction of the gross $\beta$ concentration in downstream water samples attributable to BNL effluent appears to fall off quite rapidly in the river's upper reaches. Stream bottom sampling was initiated in 1963 to obtain a profile of the distribution of radioactivity along the river downstream from the chlorine house outfall. Two sets of sediment samples were obtained in 1966. During an extensive summer program of stream sampling, effort was also directed toward the collection of identifiable species of bottom-growing plants and of turtles. $A$ few fish and one snake were also obtained. All

\section{Table 18}

1966 BNL Environmental Monitoring Concentrations in Sludge From Imhoff Tank, pCi/g

\begin{tabular}{|c|c|c|c|c|c|c|}
\hline $\begin{array}{c}\text { Date } \\
\text { removed } \\
\text { from bed }\end{array}$ & ${ }^{60} \mathrm{Co}$ & $\cos r$ & ${ }^{137} \mathrm{Cs}$ & 144Ce & $\begin{array}{c}\text { Groes } \\
\alpha\end{array}$ & $\begin{array}{c}\text { Grows } \\
\beta\end{array}$ \\
\hline $\begin{array}{l}\text { Jan. } 1966 \\
\text { Nov. } 1966\end{array}$ & $\begin{array}{l}148 \\
230\end{array}$ & $\begin{array}{r}\text { N.A. } \\
10\end{array}$ & $\begin{array}{l}38 \\
63\end{array}$ & $\begin{array}{l}26 \\
25\end{array}$ & $\begin{array}{l}26 \\
23\end{array}$ & $\begin{array}{l}550 \\
418\end{array}$ \\
\hline \multicolumn{7}{|c|}{ Estimated error, $\%$} \\
\hline \multicolumn{7}{|c|}{ Estimated Activity, mGi } \\
\hline $\begin{array}{l}\text { Jan. 1966ª } \\
\text { Nov. } 1966^{b}\end{array}$ & $\begin{array}{r}3.0 \\
11.5\end{array}$ & $\begin{array}{c}\text { N.A. } \\
0.5\end{array}$ & $\begin{array}{l}0.8 \\
3.2\end{array}$ & $\begin{array}{l}0.5 \\
1.3\end{array}$ & $\begin{array}{l}0.5 \\
1.2\end{array}$ & $\begin{array}{l}11.0 \\
20.9\end{array}$ \\
\hline Estimat & $\begin{array}{l}\text { error } \\
\pm 30\end{array}$ & \pm 30 & $\pm \mathbf{3 0}=$ & \pm 35 & \pm 30 & \pm 30 \\
\hline
\end{tabular}

Fraction of Total at Imhoff Tank Removed by Sludge Collection period

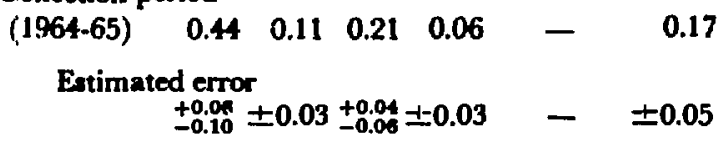

N.A. = not available.

-Tetal entimated amount, in gram, $2 \times 10^{7} \pm 25 \%$.

Total estimated amount, in grams, $5 \times 10^{7} \pm 25 \%$. 
samples were analyzed for $\gamma$-emitting isotopes. The turtles, with numbers engraved on their shells for identification, were returned to the stream at the point of collection so that they would be available for future sampling. The only nuclides detectable in most samples were ${ }^{60} \mathrm{Co}$ and ${ }^{137} \mathrm{Cs}$; however, measurable amounts of ${ }^{65} \mathrm{Zn}$ were detected in one species of stream vegetation (Vallisneria americana) as far downstream as the eastern boundary. These appear to be related to the input of ${ }^{65} \mathrm{Zn}$ to the filter beds in June 1966 (see Table 17).

The bottom sediment profile appears in Figure 15. Profiles for a species of underwater vegetation (Vallisneria americana), which was found through- out the stream, appear in Figure 16; together with concentrations found in miscellaneous vegetation species obtained on the Laboratory site.

The stream-sediment and vegetation data are generally comparable with those shown in the reports for 1964 and 1965 and confirm that most of the radioactivity contained in the Laboratory liquid effluent released to the Peconic is retained within a distance of a few miles downstream from the point of release.

The concentrations of $\gamma$-emitting nuclides in turtles from the Peconic are summarized in Table 20. Although many eastern painted turtles were easily obtained on site, too few were collected

Table 19

1966 BNL Environmental Monitoring

Monthly Stream Water Samples and Yearly Averages for 1960-1966, Gross $\beta$ Concentrations

(Values for ${ }^{3} \mathrm{H}$ in $\mathrm{nCi} /$ liter; all others in $\mathrm{PCi} /$ liter.)

\begin{tabular}{|c|c|c|c|c|c|c|c|c|c|c|c|c|c|c|}
\hline \multirow[b]{2}{*}{ Month, 1966} & \multicolumn{8}{|c|}{$\begin{array}{l}\text { Peconic River locations, proceeding } \\
\text { downstream from chlorine house }\end{array}$} & \multirow[b]{2}{*}{$\mathbf{E}$} & \multicolumn{5}{|c|}{ Control locations } \\
\hline & $\mathbf{K}$ & $\mathbf{L}$ & $\mathbf{M}$ & $\mathbf{Q}$ & $\mathbf{A}$ & B & C & D & & $\mathbf{F}$ & $\mathbf{G}$ & $\mathbf{H}$ & I & $\mathbf{J}$ \\
\hline \multicolumn{15}{|c|}{ Gross $\beta$} \\
\hline Jan. & 31 & 28 & 50 & 8 & - & 5 & 2 & $<2$ & - & 7 & - & $<2$ & 13 & \\
\hline Feb. & 23 & 21 & 62 & 45 & 15 & 10 & 4 & 3 & 5 & 8 & - & $<2$ & 12 & 3 \\
\hline Mar. & 65 & 50 & 15 & 26 & 13 & 5 & 13 & 6 & - & 13 & - & $<2$ & 16 & 16 \\
\hline Apr. & 29 & 25 & 32 & 55 & 27 & 7 & 6 & 4 & - & 3 & - & 11 & 15 & 0 \\
\hline May & 35 & 36 & - & 42 & 20 & 10 & 4 & 5 & - & 14 & - & 2 & 16 & 7 \\
\hline June & 22 & - & - & 46 & 23 & 9 & 9 & 5 & - & 18 & - & 6 & 20 & 13 \\
\hline July & 43 & 51 & - & 48 & - & 5 & 6 & - & - & - & - & 1 & 21 & 3 \\
\hline Aug. & 18 & 17 & - & 33 & - & 6 & 6 & 3 & - & 9 & - & $<1$ & 23 & 3 \\
\hline Sept. & 20 & 31 & 21 & 31 & 19 & 15 & 3 & 3 & - & 9 & - & 2 & 3 & 7 \\
\hline Oct. & 17 & 15 & 12 & 24 & 11 & 14 & 7 & 4 & - & 9 & - & 2 & 16 & 7 \\
\hline Nov. & 20 & 29 & 13 & 12 & 13 & 24 & 15 & 10 & - & 8 & - & 7 & 25 & 8 \\
\hline Dec. & 17 & 18 & 17 & 15 & 10 & 7 & 5 & 4 & - & 7 & - & 3 & 13 & 3 \\
\hline \multicolumn{15}{|c|}{$\underline{{ }^{3} \mathbf{H}}$} \\
\hline Nov. & 5 & 5 & 5 & 1 & $<1$ & $<1$ & $<1$ & $<1$ & - & $<1$ & - & $<1$ & $<1$ & $<1$ \\
\hline Da: & 10 & 10 & 14 & 4 & $<1$ & $<1$ & $<1$ & $<1$ & - & $<1$ & - & $<1$ & $<i$ & $<1$ \\
\hline \multicolumn{15}{|c|}{ Yearly Average Gross $\beta$ Concentration } \\
\hline 1966 & 29 & 29 & 28 & 32 & 17 & 10 & 7 & 4 & - & 10 & dry & 3 & 16 & 7 \\
\hline 1965 & 39 & 41 & 39 & 56 & 18 & 10 & 10 & 8 & 14 & 10 & 10 & 7 & 17 & 15 \\
\hline 1964 & 115 & 83 & 49 & 52 & 30 & 25 & 19 & 14 & 15 & 19 & 13 & 10 & 25 & 18 \\
\hline 1963 & 61 & 74 & 39 & - & 46 & 42 & 59 & 40 & 36 & 37 & 13 & 25 & 50 & 35 \\
\hline 1962 & - & - & - & - & 47 & 31 & 39 & 33 & 38 & 35 & 23 & 36 & 44 & 38 \\
\hline 1961 & - & - & -- & - & 34 & 19 & - & 17 & 17 & 10 & 6 & 9 & 14 & 16 \\
\hline 1960 & - & - & - & - & 20 & 13 & - & 11 & 8 & 5 & 7 & 9 & 13 & 6 \\
\hline
\end{tabular}

Estimated error: $<10 \mathrm{pCi} / \mathrm{liter}, \pm 2 \mathrm{pCi} / \mathrm{liter} ; 11$ to $25 \mathrm{pCi} / \mathrm{liter}, \pm 15 \% ;>25 \mathrm{pCi} / \mathrm{liter}, \pm 10 \%$. 
off site to provide a meaningful profile of concentration vs distance downstream. Except in a few of these turtles obtained at the perimeter, ${ }^{137} \mathrm{Cs}$ was the only detectable radionuclide. The highest concentration $(14.3 \mathrm{pCi} / \mathrm{g}$ ) was found in one obtained just below the chlorine house outfall, but concen-

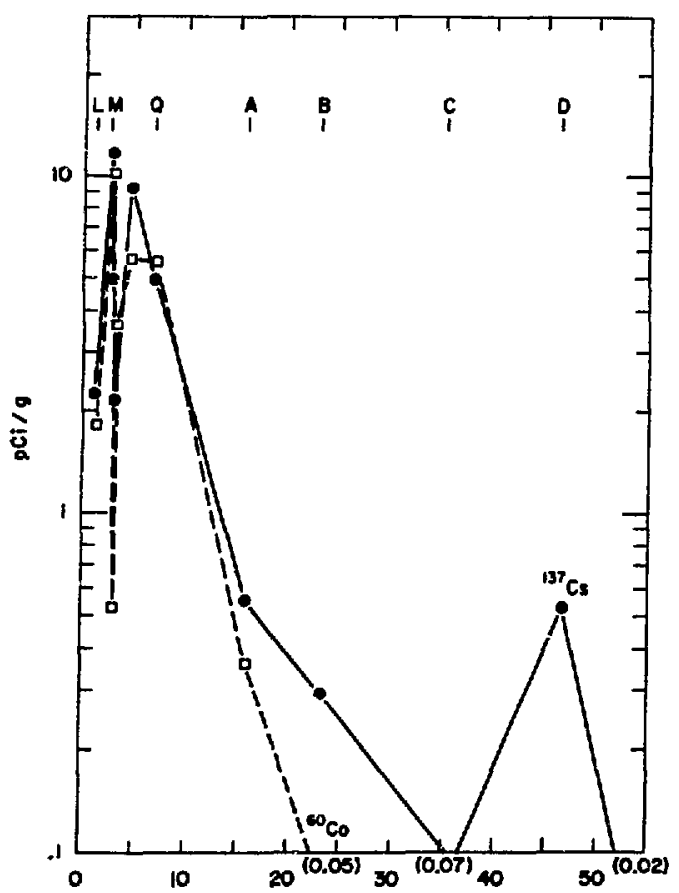

DISTANCE FROM CHLORINE HOUSE OUTFALL (THOUSANOS OF FEET)

Figure 15. Peconic River bottom sediment samples. trations almost as high (10.7 and $11.0 \mathrm{pCi} / \mathrm{g})$ were found in two turtles obtained 5 miles downstrearn.

The data for three turtles that were "repeaters" from the 1965 sampling are shown in Table 21. It appears from the two originally trapped off site and placed in the Peconic River on site in 1965

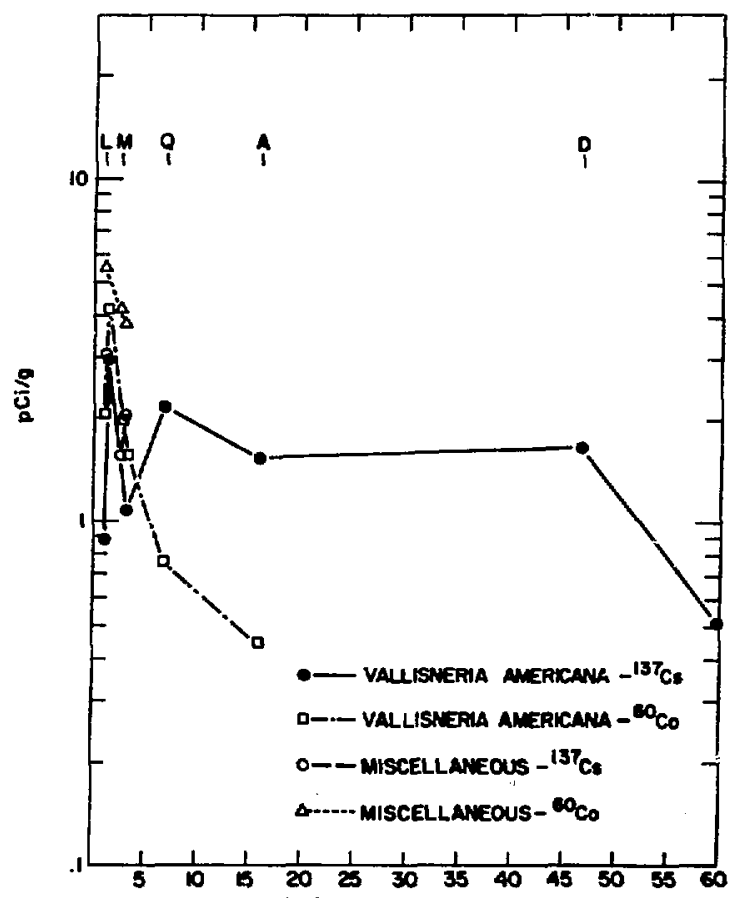

DISTANCE FROM CHLOANE HOUSE OUTFAL (THOUSANDS OF FEET)

Figure 16. Peconic River vegetation samples.

Table 20

1966 BNL Environmental Monitoring

Average Concentrations of ${ }^{*} \mathrm{Co},{ }^{*} \mathrm{Zn}$, and ${ }^{137} \mathrm{C}$ in Peconic River Turtles, $\mathrm{pCi} / \mathrm{g}$

\begin{tabular}{|c|c|c|c|c|c|c|c|c|}
\hline \multirow{3}{*}{$\begin{array}{l}\text { 'Trap location } \\
\text { (ft downtream) }\end{array}$} & \multirow[b]{3}{*}{ Stream otation } & \multicolumn{7}{|c|}{ Species } \\
\hline & & \multicolumn{4}{|c|}{ Eastern paintod } & \multicolumn{3}{|c|}{ Snapping } \\
\hline & & \multicolumn{2}{|c|}{${ }^{137} \mathrm{Ca}$} & \multirow{2}{*}{$\frac{\infty^{\infty} C_{0}}{<0.1}$} & \multirow{2}{*}{$\frac{\mu_{\mathrm{Zn}}}{<0.1}$} & \multirow{2}{*}{\multicolumn{2}{|c|}{$\frac{{ }^{197 C}}{-}$}} & \multirow{2}{*}{$\frac{{ }^{\infty} \mathrm{Co}}{-}$} \\
\hline 150 & $\mathbf{K}$ & (1) & 14.3 & & & & & \\
\hline 1,300 & $\mathbf{L}$ & (4) & 5.6 & $<0.1$ & $<0.1$ & (1) & 3.1 & 0.1 \\
\hline 1,800 & - & (4) & 2.7 & $<0.1$ & $<0.1$ & & - & - \\
\hline 2,600 & $\mathbf{M}$ & (12) & 5.1 & 0.1 & 0.1 & & - & - \\
\hline 23,100 & B & (2) & 10.9 & $<0.1$ & $<0.1$ & & - & - \\
\hline 35,500 & $\mathbf{C}$ & (2) & 2.2 & $<0.1$ & $<0.1$ & & - & - \\
\hline
\end{tabular}

- Parentheses indicate number of ammplea. 


\begin{tabular}{|c|c|c|c|c|c|}
\hline \multicolumn{6}{|c|}{$\begin{array}{c}\text { Table } 21 \\
\text { 1966 BNL Environmental Monitoring } \\
\text { Comparison of Turtles Sampled in } 1965 \text { and } 1966\end{array}$} \\
\hline \multirow{2}{*}{\multicolumn{2}{|c|}{$\begin{array}{c}\text { Specimen } \\
\text { No. }\end{array}$}} & \multirow{3}{*}{$\begin{array}{c}\begin{array}{c}\text { Trap location } \\
\text { (ft downstream) }\end{array} \\
2600 \\
1300\end{array}$} & \multirow{3}{*}{$\begin{array}{c}\begin{array}{c}\text { Weight, } \\
8\end{array} \\
240 \\
240\end{array}$} & \multicolumn{2}{|c|}{ Conc., $\mathrm{PCi} / \mathrm{g}$} \\
\hline & & & & ${ }^{137} \mathrm{C}$ & ${ }^{\circ} \mathrm{CCO}$ \\
\hline HP-3 & $\begin{array}{l}1965 \\
1966\end{array}$ & & & $\begin{array}{l}6.3 \\
3.9\end{array}$ & $\begin{array}{l}<0.1 \\
<0.1\end{array}$ \\
\hline HP-5 & $\begin{array}{l}1965 \\
1966\end{array}$ & $\begin{array}{c}\text { Off site } \\
1860\end{array}$ & $\begin{array}{l}553 \\
547\end{array}$ & 3.9 & 0.9 \\
\hline HP-13 & $\begin{array}{l}1965 \\
1966\end{array}$ & $\begin{array}{c}\text { Off site } \\
1300\end{array}$ & $\begin{array}{l}275 \\
270\end{array}$ & $\begin{array}{l}0.1 \\
1.3\end{array}$ & $\begin{array}{l}<0.1 \\
<0.1\end{array}$ \\
\hline
\end{tabular}

*Not analyzed in 1965; obtained from same off-site location as HP-13.

Table 22

1966 BNL Environmental Monitoring

Concentrations of ${ }^{137} \mathrm{Cr},{ }^{65} \mathrm{Zn},{ }^{60} \mathrm{Co}$, and ${ }^{40 \mathrm{~K}}$ in Miscellaneous Peconic River Fauna

(Values for $\mathrm{K}$ in $\mathrm{g} / \mathrm{kg}$; all others in $\mathrm{pCi} / \mathrm{g}$.)

\begin{tabular}{lcccccc}
\hline & $\begin{array}{c}\text { Location } \\
\text { (ft downstream) }\end{array}$ & $137 \mathrm{Cs}$ & $05 \mathrm{Zn}$ & 0iCo & $40 \mathrm{~K}$ \\
\hline Snapping turtle & 1300 & 3.10 & - & 0.07 & - \\
Bullhead & 2600 & 1.64 & - & - & - \\
Snake & & & & & & \\
$\quad$ (Eastern racer) & 2600 & 6.90 & - & 0.14 & - \\
Bluegill & 2700 & 6.00 & 0.38 & 0.04 & 3.74 \\
Bluegill & 2700 & 6.09 & 0.65 & 0.75 & 3.47 \\
Catfish & 6900 & 4.60 & - & 0.20 & 3.38 \\
\hline
\end{tabular}

that this species came to near equilibrium with the ambient concentrations within 1 yr. Similar data on the $\gamma$-emitting nuclides in other animals obtained in the Peconic are summarized in Table 22.

Through the cooperation of the Suffolk Health Departmenc a sample of clams from the mouth of the Peconic River was obtained on July 18 . The results of the assay for $\gamma$-emitting isotopes are shown in Table 23. No activity attributable to the Laboratory effluent could be detected.

Since there is an abundant underground supply of water on Long Island, the Peconic River is not ued to supply drinking water or for irrigation. Its waters are occasionally used to flood the lower bog of a commercial cranberry operation eight miles downstream. Although they were not so used in 1966, one sample of berries from the lower bogs of this farm was obtained in October. The only
Table 23

1966 BNL Environmental Monitoring $\gamma$-Emitting Radioactivity in Clams at Mouth of Peconic River, July 18

(Values for $\mathrm{K}$ in $\mathrm{g} / \mathrm{kg}$; all others in $\mathrm{pCi} / \mathrm{kg}$.)

\begin{tabular}{|c|c|c|c|c|c|}
\hline & $\mathbf{s} \mathbf{M n}$ & ${ }^{137} \mathrm{Cs}$ & $\mathbf{U}$ & Th & $\mathbf{K}$ \\
\hline $\begin{array}{l}\text { Meat } \\
\text { Sheils }\end{array}$ & $\begin{array}{l}30 \\
30\end{array}$ & $\begin{array}{l}90 \\
80\end{array}$ & $\begin{array}{l}230 \\
390\end{array}$ & $\begin{array}{r}110 \\
80\end{array}$ & $\begin{array}{l}2.13 \\
0.93\end{array}$ \\
\hline \multicolumn{3}{|c|}{ Estimated error, \% } & \pm 50 & \pm 50 & \pm 0.2 \\
\hline
\end{tabular}

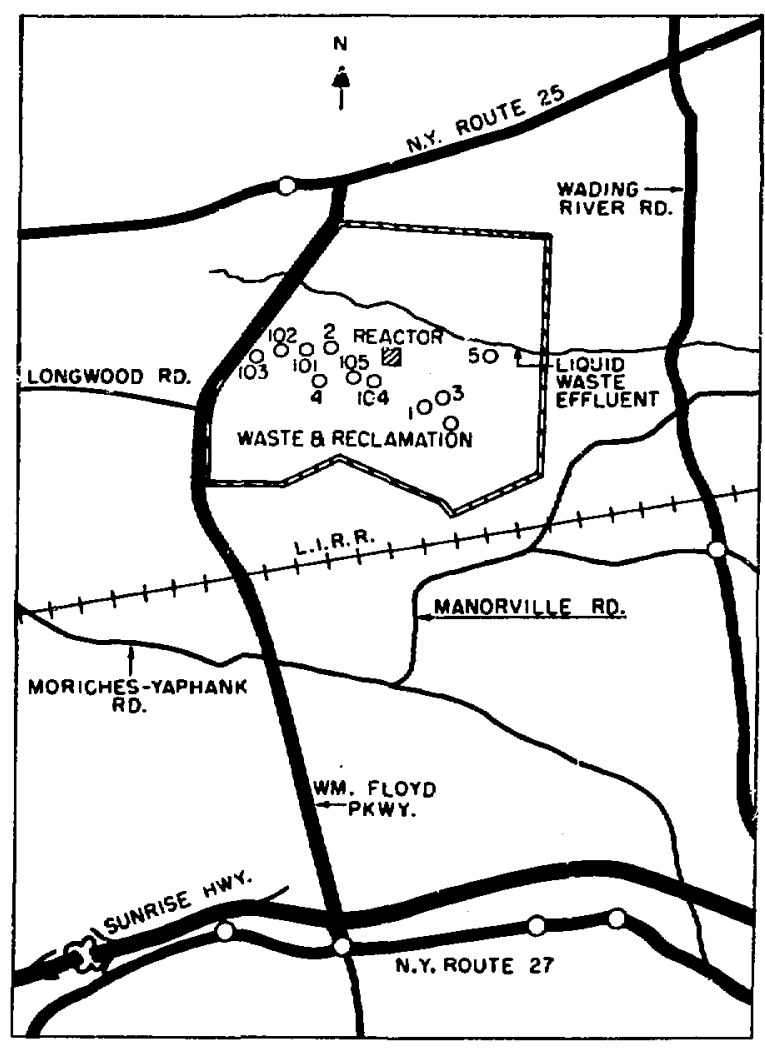

Figure 17. Location of BNL water supply wells.

identifiable $\gamma$-emitting isotope found was ${ }^{137} \mathrm{Cs}$ (1.04 $\mathrm{pCi} / \mathrm{g}$ ).

\section{WEL SAMPLING}

The Laboratory's potable water wells and cooling water supply wells are about $100 \mathrm{ft}$ deep or $50 \mathrm{ft}$ below the water table in the Long Island surface layer of glacial outwash sand and gravel. They are also generally west to northwest and up- 
Table 24

1966 BNL Environmental Monitoring

Gross $\boldsymbol{\beta}$ Concentrations in Deep Well Samples, pCi/liter

\begin{tabular}{|c|c|c|c|c|c|c|c|c|}
\hline \multirow[b]{2}{*}{ Month } & \multicolumn{7}{|c|}{ Potable water well no. } & \multirow[b]{2}{*}{$\mathbf{W} \& \mathbf{R}$} \\
\hline & 1 & 2 & 3 & 4 & 5 & 6 & 7 & \\
\hline Jan. & $<1.6$ & $<1.5$ & $<1.6$ & 2.4 & 2.9 & 1.5 & 3.7 & 1.2 \\
\hline Feb. & - & - & - & 2.4 & $<1.1$ & $<1.1$ & $<1.1$ & $<1.2$ \\
\hline Mar. & $<1.1$ & $<1.1$ & $<1.1$ & $<1.1$ & $<1.1$ & - & - & $<0.8$ \\
\hline Apr. & $<1.0$ & $<1.0$ & $<1.0$ & 5.4 & 2.7 & 2.1 & $<1.0$ & $<1.0$ \\
\hline May & 1.8 & 2.5 & $<0.9$ & 2.2 & 1.2 & $<0.9$ & 0.9 & $<0.9$ \\
\hline June & $<1.0$ & 1.2 & 1.0 & 2.0 & 1.1 & 2.0 & $<1.0$ & 1.0 \\
\hline July & $<1.0$ & 2.1 & $<1.0$ & 1.4 & $<1.0$ & $<1.0$ & 2.0 & $<1.0$ \\
\hline Aug. & 1.6 & $<1.0$ & 1.4 & $<1.0$ & 1.6 & 2.1 & $<1.0$ & $<1.0$ \\
\hline Sept. & $<1.0$ & $<1.0$ & $<1.0$ & 1.1 & $<1.0$ & 1.5 & $<1.0$ & $<1.0$ \\
\hline Oct. & 2.2 & $<1.0$ & $<1.0$ & $<1.0$ & $<1.0$ & 1.5 & $<1.0$ & $<1.0$ \\
\hline Nov. & - & 1.2 & 1.1 & 1.6 & 1.5 & $<1.0$ & 1.1 & 1.1 \\
\hline Dec. & 2.0 & 1.4 & 5.6 & 2.5 & 1.4 & 1.6 & 1.1 & 0.9 \\
\hline Av & 1.1 & 1.1 & 0.7 & 1.8 & 1.3 & 1.3 & 1.1 & 0.7 \\
\hline
\end{tabular}

Cooling supply well no.

\begin{tabular}{lrrrrr}
\cline { 2 - 6 } Month & 101 & 102 & 103 & 104 & \multicolumn{1}{c}{105} \\
\hline Jan. & - & $<1.5$ & $<1.5$ & $<1.8$ & $<1.5$ \\
Feb. & $<1.1$ & $<1.1$ & $<1.1$ & 1.2 & $<1.1$ \\
Mar. & $<1.1$ & $<1.1$ & $<1.1$ & $<1.1$ & $<1.4$ \\
Apr. & - & $<1.0$ & $<1.0$ & - & 5.1 \\
May & - & $<0.9$ & $<1.0$ & $<1.0$ & $<1.0$ \\
June & - & $<1.0$ & 6.9 & 4.5 & 1.3 \\
July & $<1.0$ & 1.9 & $<1.0$ & 1.9 & 2.1 \\
Aug. & $<1.0$ & 1.4 & 1.9 & 2.0 & 2.0 \\
Sept. & $<1.0$ & $<1.0$ & 2.3 & 1.4 & $<1.0$ \\
Oct. & $<1.0$ & $<1.0$ & 2.1 & $<1.0$ & 2.0 \\
Nov. & $<1.0$ & 1.0 & 1.0 & $<1.0$ & 2.0 \\
Dec. & 1.7 & $<0.9$ & 1.4 & - & 1.0 \\
Av & 0.7 & 0.8 & 1.6 & 1.4 & 1.5
\end{tabular}

* Waste disposal and reclamation well.

stream from most of the Laboratory's facilities. The exceptions are principal potable water wells Nos. 1 and 3, the smaller well (No. 5) at the sewage plant, and the one at the waste and reclamation area (see Figure 17). Monthly groses $\beta$ results are summarized inTable 24. Less-than-background values have been assumed to be $50 \%$ of the detection limit in calculating yearly averages. No tignificant differences from the previous sampling were apparent except for well No. 5 at the sewage. plant, which averaged $1.3 \mathrm{pCi} /$ liter compared with 5.3 in 1965.

\section{VECTATION AND SOIL SAMPUNG}

In addition to routine sampling early and late in the summer, a number of grass samples were secured from nearby farms (at most of which milk and soil samples were also obtained) to ascertain the levels of fallout nuclides during the few weeks after the May and October Chinese weapons tests. Most of the fallout activity observed in these samples appears to have been deposited during everal periods of light to moderate precipitation late in May and early in June and November. 
'Iuble '2!'

ISWiti MNI, Enviromemental EAunituritun

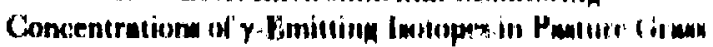

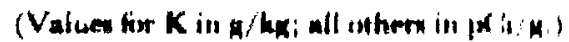

\begin{tabular}{|c|c|c|c|c|c|c|c|c|c|c|c|c|}
\hline Location & Month & $\begin{array}{l}\text { No. of } \\
\text { namples }\end{array}$ & The & ${ }^{s} \mathrm{Mn}$ & $\begin{array}{l}m / n^{\prime} \\
m n N h\end{array}$ & lank $k_{11}$ & $\mid 111$ & 1111 in & 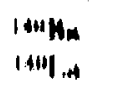 & 1118 & $14+14$ & $k$ \\
\hline \multirow{6}{*}{$\begin{array}{l}\text { Farm A, } \\
3 \mathrm{~km} \mathrm{NW}\end{array}$} & May & 3 & 873 & $<\operatorname{lox}(x)$ & 6201 & Ine & $1 \mathrm{H}$ & 1101 & וניו & HWH & & int \\
\hline & June & 1 & N.A & $\alpha(x)$ & $M(x)$ & $=230$ & & 1116 & $1+1$ & ? & & illi" \\
\hline & July & 1 & $=\infty$ & $<(0)$ & 44) & & & & IIni & InI & & $\||x|$ \\
\hline & Aug & 1 & 1872 & $<i(x)$ & hiJk & $=2131$ & & .1:! & & - :n1 & & Alli \\
\hline & Oct. & 1 & 3260 & $<100$ & 217 & & & 1111 & & & $|1| 4 \mid$ & ||$v \mid$ \\
\hline & \multicolumn{2}{|c|}{ Av } & 2002 & $<100$ & 41.1 & & & I $W_{1}$ & & & & inti \\
\hline \multirow{6}{*}{$\begin{array}{l}\text { Farm B, } \\
6 \mathrm{~km} \mathrm{SW}\end{array}$} & May & 2 & $<1000$ & $<100$ & tids & 14 i & ItiH & 401 & Wn! & $\therefore 4 i_{i}$ & & 5.24 \\
\hline & June & 1 & N.A. & $<100$ & 224 & $\cdot 2(x)$ & $\mathbf{N} \mathbf{A}$ & $\cdot(x)$ & $16 !$ & $|N|$ & & fent \\
\hline & July & 1 & 2910 & $<100$ & $2(20)$ & & & $|(4)|$ & $\mid 211$ & 2111 & & 4.:N1 \\
\hline & Aug. & 1 & 1215 & $<100$ & B42 & 452 & 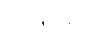 & $\mid(m)$ & & $22 k 1$ & & 6.14 \\
\hline & Nov. & 2 & 768 & $<100$ & $<230$ & & . & $H(n)$ & $\Rightarrow(m)$ & & $2(x)$ & +45 \\
\hline & \multicolumn{2}{|c|}{ Av } & 1348 & $<100$ & 404 & & & $17: 1$ & & & & 6.57 \\
\hline \multirow{6}{*}{$\begin{array}{l}\text { Farm C, } \\
\qquad 10 \mathrm{~km} \mathrm{SE}\end{array}$} & May & 1 & $<1000$ & $<100$ & 663 & 178 & 116 & $2 \times 3)$ & 147 & $=250$ & & 4.34 \\
\hline & June & 1 & N.A. & $<100$ & 2940 & 46.3 & N.A. & N.A. & 1074 & 316 & 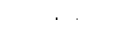 & 3.46 \\
\hline & July & 1 & - & $<100$ & 2240 & $\cdots$ & $\ldots$ & !170 & $1(x)$ & bot & $\cdots$ & 12.70 \\
\hline & Oct. & 1 & 1090 & $<100$ & $<230$ & - & - & 78 & 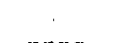 & $\cdots$ & .547 & .3.4.5 \\
\hline & Nov. & 1 & 9650 & $<100$ & 3120 & - & 1310 & 400 & $9 \times 00$ & 11:15 & $\cdots$ & - \\
\hline & \multicolumn{2}{|c|}{ Av } & 3747 & $<100$ & 1818 & & & $24: 3$ & & & & 6.16 \\
\hline \multirow{5}{*}{$\begin{array}{l}\text { Farm D, } \\
15 \mathrm{~km} \mathrm{NW}\end{array}$} & May & 1 & $<1000$ & $<100$ & 407 & $<\mathbf{2 5 0}$ & 197 & $<230$ & 776 & $<250$ & - & 4.36 \\
\hline & June & 1 & N.A. & $<100$ & 313 & 544 & $<50$ & N.A. & 343 & $<250$ & - & 4.95 \\
\hline & July & 1 & 3940 & $<100$ & $<250$ & - & - & 180 & 1300 & 470 & - & 8.50 \\
\hline & Oct. & 1 & 749 & $<100$ & $<250$ & - & - & 85 & - & - & 381 & 4.77 \\
\hline & \multicolumn{2}{|c|}{ Av } & 1730 & $<100$ & 242 & & & 130 & & & & 5.64 \\
\hline $\begin{array}{l}\text { Farm F, } \\
30 \mathrm{~km} \mathrm{E}\end{array}$ & July & 1 & 2210 & $<100$ & 250 & - & - & 100 & 730 & 250 & - & 2.50 \\
\hline $\begin{array}{l}\text { Farm H, } \\
6 \mathrm{~km} \mathrm{NE}\end{array}$ & July & 1 & 5410 & $<100$ & 1110 & - & - & 320 & 790 & 250 & - & 4.50 \\
\hline \multirow[t]{7}{*}{ BNL site } & Apr. & 4 & 4327 & 295 & $<250$ & - & 64 & 1317 & - & - & $\$ 01$ & 3.80 \\
\hline & May & 1 & $<1000$ & $<100$ & 735 & $<250$ & 277 & 300 & 1205 & 702 & - & N.A. \\
\hline & July & 1 & 7620 & $<100$ & 4340 & - & - & 1065 & 300 & 325 & - & 7.80 \\
\hline & Aug. & 6 & 5970 & $<100$ & 3543 & $<250$ & - & 1101 & - & 348 & - & 4.15 \\
\hline & Sept. & 2 & 1724 & $<100$ & $<250$ & - & 63 & 152 & - & - & $<250$ & 5.89 \\
\hline & Oct. & 1 & 671 & $<100$ & $<250$ & - & - & 400 & - & - & $<250$ & 3.50 \\
\hline & \multicolumn{2}{|c|}{ Av } & 3469 & 91 & 1306 & & & 756 & & & & 5.03 \\
\hline \multicolumn{3}{|c|}{$\begin{array}{l}\text { Eximated error of } \\
\text { individual anmple }\end{array}$} & $\begin{array}{c} \pm 25 \% \\
\text { or } \\
\pm 500^{*}\end{array}$ & $=100 \%$ & $\begin{array}{c} \pm 10 \% \\
\text { or } \\
\pm 50\end{array}$ & $\begin{array}{c} \pm 30 \% \\
\text { or } \\
\pm 250\end{array}$ & $\begin{array}{l} \pm 25 x \\
+0 x \\
\pm 50\end{array}$ & $\begin{array}{l} \pm 10 \% \\
\text { or } \\
\pm 100\end{array}$ & $\begin{array}{l} \pm 25 \% \\
0 x \\
\pm 100\end{array}$ & $\begin{array}{l} \pm 25 \% \\
\text { or } \\
\pm 250\end{array}$ & $\begin{array}{l} \pm 25 \% \\
\quad \text { or } \\
\pm 250\end{array}$ & \pm 0.5 \\
\hline
\end{tabular}

N.A. = not avilable.

Whichever is reater. 
Table 26

I (insentrations of $y$-Emitting Inotopes in Soil (Values for $\mathrm{K}$ in $\mathrm{g} / \mathrm{kg}$; all others in $\mathrm{pCi} / \mathrm{kg}$.)

\begin{tabular}{|c|c|c|c|c|c|}
\hline Location & Month & ${ }^{137} \mathrm{C}$ & $U_{m}$ & $T_{h}$ maxe & $\mathbf{F}$ \\
\hline Farm A & $\begin{array}{l}\text { Mar. } \\
\text { July }\end{array}$ & $\begin{array}{r}440 \\
<250\end{array}$ & $\begin{array}{c}\text { N.A. } \\
"\end{array}$ & $\begin{array}{c}\text { N.A. } \\
"\end{array}$ & $\begin{array}{l}5.5 \\
5.7\end{array}$ \\
\hline Farm B & Oct. & 530 & 940 & 740 & 7. \\
\hline Farm C & $\begin{array}{l}\text { July } \\
\text { Oct. }\end{array}$ & $\begin{array}{l}<250 \\
1110\end{array}$ & $\begin{array}{r}17 \$ 0 \\
690\end{array}$ & $\begin{array}{r}1600 \\
550\end{array}$ & $\begin{array}{l}6.2 \\
4.5\end{array}$ \\
\hline Farm D & $\begin{array}{l}\text { July } \\
\text { Oct. }\end{array}$ & $\begin{array}{l}<250 \\
<250\end{array}$ & $\begin{array}{l}2200 \\
1350\end{array}$ & $\begin{array}{l}2200 \\
1000\end{array}$ & $\begin{array}{l}8.4 \\
9.5\end{array}$ \\
\hline Farm F & $\begin{array}{l}\text { July } \\
\text { Oct. }\end{array}$ & $\begin{array}{r}960 \\
<250\end{array}$ & $\begin{array}{l}1200 \\
1290\end{array}$ & $\begin{array}{l}1800 \\
1120\end{array}$ & $\begin{array}{r}2.9 \\
12.5\end{array}$ \\
\hline Farm H & July & 1995 & 1200 & 1800 & 7.7 \\
\hline Av & & 566 & 1321 & 1361 & 7.0 \\
\hline \multicolumn{6}{|c|}{$\begin{array}{r}\text { Eximated error (individual sample) } \\
\pm 250 \quad \pm 500\end{array}$} \\
\hline
\end{tabular}

N.A. = not available.

About $25 \%$ of the 131 I depoxited in precipitation on May 19 and 22 and about $35 \%$ of that deposited on Nov. 6 appear to have been retained on the grass.

Concentrations of identifiable $\gamma$-emitting isotopes in these pasture samples are summarized in Table 25. The concentrations of these isotopes in both precipitation and pasture vegetation declined markedly in comparion with 1965 data.

The average 131 I deponition of two grass samples, obtainod on Apr. 22 (at stations S-6 and S-13) in connection with the ${ }^{131}$ I release from the Hot Laboratory, was $75 \mathrm{pCi} / \mathrm{kg}$. The corresponding calculated deponition velocity was about $0.5 \pm 0.3 \mathrm{~cm} / \mathrm{sec}$.

Samples of the top $6 \mathrm{in}$. of soil were obtained in July and October from most of the farms in the vicinity of the Laboratory from which vegetation samples were secured. The concentrations of identifiable $\gamma$-emitting isotopes present appear in Table 26. The concentrations of natural uranium and thorium were determined by comparison with the $\gamma$ spectrum of ealibrated ore samples.

\section{Mrx sanmino}

Meteorological predictions of average ground concentrations of 131 I emitted from the $3 G R R$,

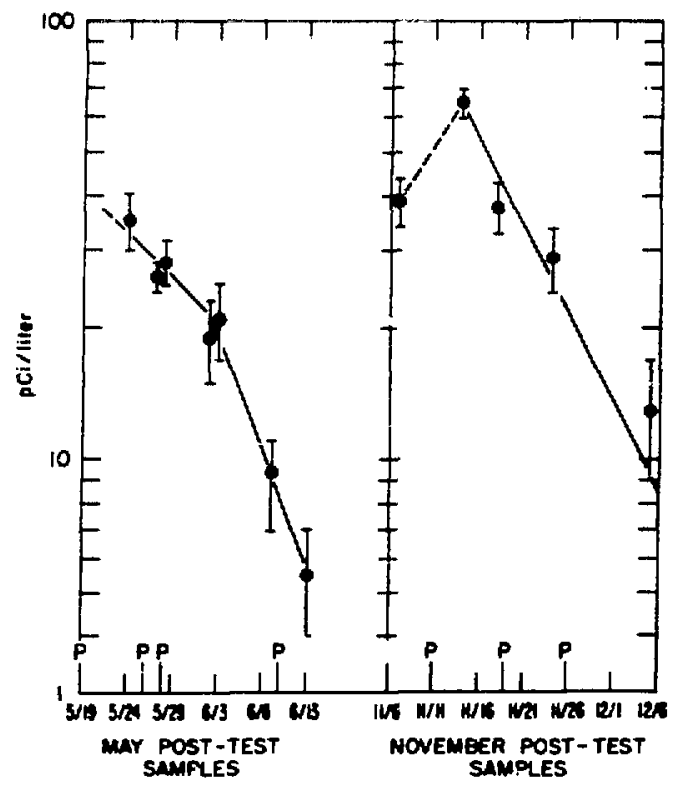

Figure 18. Pont-test concentrations of 131 in milk, May and November, 1966. $P$ =measurable precipitation.

with reasonable assumptions about its deposition and about the relationship between grass and milk concentrations, led to the conclusion that the concentration of Laboratory-released 131 I in the milk from cows pastured in the vicinity would generally be $<1 \mathrm{pCi} /$ liter, or well below the lower limit of detection. This expectation was confirmed by the measurements.

The concentrations of ${ }^{137} \mathrm{Cs}$ and the amounts of potaxium in routine monthly samples are shown in Table 27. For locations sampled more than once, the number of samples is shown in parentheses and the ${ }^{137} \mathrm{C}$ s and $\mathrm{K}$ values are averages. Samples with a concentration of 131 I $>2 \mathrm{pCi} /$ liter are also listed by date and location. The applicable radiation protection guide for 131 , axuming an intake of 1 liter/day, is $100 \mathrm{pCi} /$ liter.

Measurable concentrations of 131 I were generally evident shortly after the srrival of debris from the May and late October Chinese tests. The data for the several milk amples collected during and shortly after the largeat depositions of 131 I late in May are shown in Figure 18. Weekly precipitation amples indicate that about $4 \mathrm{nCi} / \mathrm{m}^{2}$ of 131 I was deponited in each of the last two weeks in May. Meanurable precipitation was collected on May 24 and 26. Only trace amounts occurred between then and June 10. The decline in 131 I concentra- 
Table 27

1966 BNL Environmental Monitoring

Concentrations of ${ }^{131} I,{ }^{137} \mathrm{C}$, and $\mathrm{K}$ in Milk Samples

(Values for $\mathrm{K}$ in $\mathrm{g} /$ liter; for ${ }^{137} \mathrm{Cs}$, in $\mathrm{PCi} /$ liter.)

\begin{tabular}{|c|c|c|c|c|c|c|c|c|}
\hline \multirow[b]{2}{*}{ Month } & \multicolumn{2}{|c|}{$\begin{array}{c}\text { Ganie } \\
\operatorname{farm}(\mathbf{A}), \\
3 \mathrm{~km} \mathrm{NW}\end{array}$} & \multicolumn{2}{|c|}{$\begin{array}{c}\text { Suffolk County } \\
\text { farm (B), } \\
6 \mathrm{~km} \mathrm{SW}\end{array}$} & \multicolumn{2}{|c|}{$\begin{array}{c}\text { Thees } \\
\text { farm (C), } \\
10 \mathrm{~km} \mathrm{SE}\end{array}$} & \multicolumn{2}{|c|}{$\begin{array}{l}\text { Randalls } \\
\text { farm (D), } \\
15 \mathrm{~km} \mathrm{NW}\end{array}$} \\
\hline & ${ }^{137} \mathrm{Cs}$ & $\mathbf{K}$ & ${ }^{137} \mathrm{Cs}$ & $\mathbf{K}$ & ${ }^{137} \mathrm{Cs}$ & $\mathbf{K}$ & ${ }^{137} \mathrm{Cs}$ & $\mathbf{K}$ \\
\hline Jan. & 58 & 1.6 & 113 & 1.6 & 81 & 1.2 & 67 & 1.2 \\
\hline Feb. & 44 & 1.5 & 62 & 1.0 & 48 & 1.9 & 57 & 1.6 \\
\hline Mar. & 52 & 1.1 & 32 & 1.5 & 70 & 1.5 & 37 & 1.1 \\
\hline Apr. & (2) 40 & 1.3 & (2) 58 & 1.3 & 71 & 1.5 & 45 & 1.5 \\
\hline May & (2) 52 & 1.4 & (3) 45 & 1.5 & 52 & 1.3 & (2) 46 & 1.4 \\
\hline June & (2) 46 & 1.4 & (2) 64 & 1.4 & (2) 62 & 1.4 & (2) 45 & 1.5 \\
\hline July & - & - & 41 & 1.4 & 72 & 1.6 & 4 & 1.5 \\
\hline Aug. & 40 & 1.0 & 61 & 1.4 & 38 & 1.4 & 28 & 1.4 \\
\hline Sept. & - & - & 52 & 1.6 & 34 & 1.3 & 41 & 1.1 \\
\hline Oct. & - & - & 41 & 1.6 & 33 & 1.6 & 59 & 1.5 \\
\hline Nov. & 36 & 1.5 & (4) 48 & 1.7 & (4) 46 & 1.6 & (2) 30 & 1.4 \\
\hline Dec. & 41 & 1.3 & 47 & 1.6 & 65 & 1.6 & 46 & 1.7 \\
\hline Yearly av & 45 & 1.3 & 55 & 1.5 & 56 & 1.5 & 46 & 1.4 \\
\hline
\end{tabular}

Estimated error (individual samples): ${ }^{137} \mathrm{Cs}, \pm 15 \mathrm{pCi} /$ liter; $\mathrm{K}, \pm 0.2 \mathrm{~g} /$ liter.

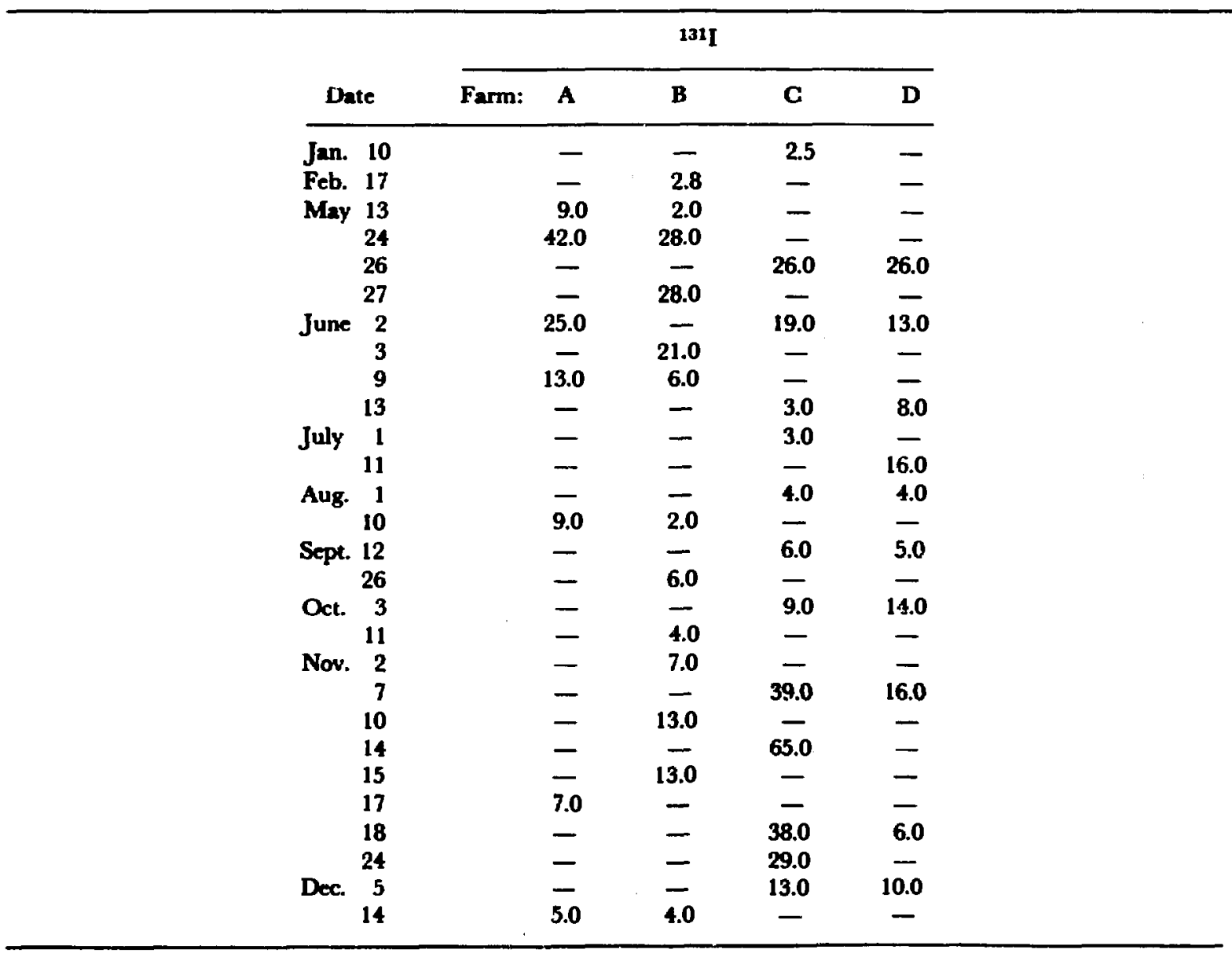

Extimated error: 2 to $5 \mathrm{pCi} / \mathrm{liter}, \pm 50 \% ; 5$ to $25 \mathrm{pCi} / \mathrm{liter}, \pm 35 \% ;>25 \mathrm{pCi} / \mathrm{liter}, \pm 20 \%$. 
Table 29

1966 BNL Environmental Monitoring

Table 28

1966 BNL Environmental Monitoring

Gross $\beta$ and Tritium Concentrations in Recharge Basins

(Values for ${ }^{3} \mathrm{H}$ in $\mathrm{nCi} /$ liter; for gross $\beta$, in $\mathrm{pCi} /$ liter.)

\begin{tabular}{|c|c|c|c|}
\hline \multirow[b]{2}{*}{ Month } & \multicolumn{3}{|c|}{ Location } \\
\hline & $\begin{array}{c}\text { North of } \\
\text { AGS }\end{array}$ & $\begin{array}{l}\text { East of } \\
\text { BGRR }\end{array}$ & $\begin{array}{l}\text { Medica } \\
\text { complex }\end{array}$ \\
\hline \multicolumn{4}{|c|}{ Groes $\beta$} \\
\hline Jan. & 3 & 1 & 2 \\
\hline Feb. & 13 & $<2$ & $<2$ \\
\hline Mar. & 5 & 3 & 2 \\
\hline Apr. & 5 & 5 & - \\
\hline May & 5 & 3 & $<1$ \\
\hline June & 5 & 2 & 1 \\
\hline July & 8 & 2 & $<1$ \\
\hline Aug. & 5 & 2 & 2 \\
\hline Sept. & 4 & $<1$ & 1 \\
\hline Oct. & 3 & 2 & $<1$ \\
\hline Nov. & 6 & 2 & 2 \\
\hline Dec. & 4 & 2 & 15 \\
\hline Av & 6 & 2 & 2 \\
\hline \multicolumn{4}{|c|}{${ }^{3} \mathbf{H}$} \\
\hline Nov. & $<1$ & $<1$ & $<1$ \\
\hline Dec. & $<1$ & 3 & 4 \\
\hline
\end{tabular}

tions in milk obtained during this period suggests an effective half-time of about 5.5 days. The concentrations of $131 \mathrm{I}$ in milk from the one farm at which cows were on pasture throughout November are also shown in Figure 18. The sampling data do not reflect the maximum concentration, which was probably about $100 \mathrm{pCi} /$ liter about Nov. 10. The half-time appears to be about 8 days, but this may reflect the several small precipitation depositions during November.

The May and November data are generally consistent with those reported for this region by the U.S. Public Health Service. ${ }^{23}$ It is readily apparent from Table 27 that during the latter period only the herd at Farm $\mathrm{C}$ was consistently on pas-. ture. This suggests that during marginal pasture conditions, differences in feeding practicen can pro duce order-of-magnitude differences in the amount of 131 I reaching dairy cows in the an me milkxhed area.

\section{on-sit: sumes}

Monitoring for the pomible entry of radiunativ. ity into the ground water included thiee reclinugr
Dump Disposal of Contaminated Waste, 1964-66

\begin{tabular}{|c|c|c|c|c|}
\hline \multirow[b]{2}{*}{ Year } & \multirow[b]{2}{*}{ Month } & \multicolumn{3}{|c|}{ Activity, $\mu \mathrm{Ci}$} \\
\hline & & $\begin{array}{c}\text { Class I } \\
\left(T_{1 / 2}\right. \\
<100 \text { days })\end{array}$ & $\begin{array}{c}\text { Class } 11 \\
\left(T_{1 / 2}\right. \\
100 \text { days-5 yr })\end{array}$ & $\begin{array}{l}\text { Class III } \\
\left(T_{1 / 2}\right. \\
>5 \mathrm{yr})\end{array}$ \\
\hline \multicolumn{5}{|l|}{1964} \\
\hline & Jan. & 225 & 35 & 28 \\
\hline & Fet. & 1,274 & 714 & 8,379 \\
\hline & Mar. & 56 & 89 & 5,263 \\
\hline & Apr. & 598 & 2,687 & 7,631 \\
\hline & May & 1,258 & 716 & 5,770 \\
\hline & June & 90 & 540 & 3,984 \\
\hline & July & 518 & 420 & 859 \\
\hline & Aug. & 223 & 480 & 3,218 \\
\hline & Sept. & 163 & 162 & 5,188 \\
\hline & Oct. & 264 & 67 & 10,312 \\
\hline & Nov. & 1,473 & 34 & 13,343 \\
\hline & Dec. & 46 & 109 & 6,502 \\
\hline & Total & 6,188 & 6,053 & 70,477 \\
\hline & & 516 & 504 & 5,873 \\
\hline & able limit & 0.069 & 0.605 & 70.4 \\
\hline \multicolumn{5}{|l|}{1965} \\
\hline & Jan. & 145 & 186 & 12,281 \\
\hline & Feb. & 536 & 62 & 8,030 \\
\hline & Mar. & 148 & 0 & 5,616 \\
\hline & Apr. & 279 & 27 & 7,272 \\
\hline & May & 3,788 & 30 & 890 \\
\hline & June & 174 & 224 & 4,012 \\
\hline & Inulv & 51 & 97 & 7,880 \\
\hline & Aug. & 0 & 0 & 0 \\
\hline & Sept. & 327 & 174 & 20,063 \\
\hline & Oct. & 20 & 0 & 9,808 \\
\hline & Nov. & 215 & 0 & 14,256 \\
\hline & Dec. & 35 & 1 & 9,311 \\
\hline & Total & 5,718 & 801 & 99,413 \\
\hline & $\begin{array}{l}\text { Av } \\
\text { \% of ailow- }\end{array}$ & 520 & 73 & 9,038 \\
\hline & able limit & 0.063 & 0.08 & 99.4 \\
\hline
\end{tabular}

1966

\begin{tabular}{|c|c|c|c|}
\hline Jan. & 311 & 233 & $14,027^{*}$ \\
\hline Feb. & 177 & 1,168 & 823 \\
\hline Mar. & 927 & 3,262 & 480 \\
\hline$A_{p} p r$ & $46 t$ & 12,114 & 505 \\
\hline May & $1,:(n)$ & 6,377 & 370 \\
\hline June & 0 & ) & 0 \\
\hline July & "1 & 0) & 0 \\
\hline Auix. & :Hii & $7,4: 17$ & .507 \\
\hline . ון. & $0.197 \%$ & $.956 i$ & 1,027 \\
\hline $1 x-1$ & 1,476 & 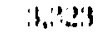 & 1.92 .5 \\
\hline$N_{11}$ & INI & (HWK) & $3 t i t i$ \\
\hline I H.: & 1 & $(1,1,1,1$ & $2, f(1) 2$ \\
\hline linal & $|1| 1 \mid\}$, & $1: 1111$ & $22,(k) 2$ \\
\hline & 1.1111 & $1,2(111$ & 2,2 titit \\
\hline 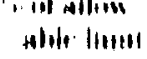 & 111 & I..1!! & 296 \\
\hline
\end{tabular}

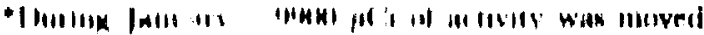

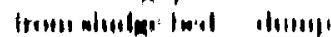


basins, one norts of the Alternating Gradient Synchrotron, one east of the BGRR, and one south of the Medical complex, into which secondary cooling water from these facilities is dischaged. These sumpare aleo open to surface runof, and, as shown in Table 28 , their gross $B$ concentrations appear to follow the concentration trends reported in the section on stream sampling. Analysis of these samples for ${ }^{3} \mathrm{H}$ was initiated in Novem. ber, and thewe data are also shown in Table 28.

\section{ONESII SOUD WASTE DISPOSAL}

Small quantities of solid radiontive wastes may be dispoeed of in the ground locally under an AEC apponved policy 24 that allows a total of $10 \mathrm{Ci}$ of radioactivity a year to be piaced in the open-pit burial ground located in the southeastern part of the Laboratory site (see Figure 2). However, further reatrictions are imposed on the basis of halflife, as follows.

(1) Of the $10 \mathrm{Ci}$ total activity, no more than $1 \mathrm{Ci}$ may have a half-life $>100$ days.

(2) Of this $1 \mathrm{Ci}$, no more than $100 \mathrm{mCi}$ may have a half-life $>5 \mathrm{yr}$.

(3) No more than $1 \mathrm{mCi}$ of radium and plutonium may be dispoed of in this manner per year.
The amounts of radioactive solid waste with the percentages of allowable activity per class that have been disposed of on the Brookhaven openpit dump since 1964 are listed in Table 29.

\section{SPECIAL MOJECTS}

\section{Whola-Body Burden and 24hr Eliminetien of 19re.}

In mid-1964 a prograrn in cooperation with the Medical Department was initiated to gather data for a comparison of human body burdens and 24-hr urine sample levels of ${ }^{137} \mathrm{Cs}$. Because of the decline in prevailing concentrations, this program was concluded in mid-1966. A summary of the quarterly average body burdens, urine concentrations, and daily excretion is presented in Table $\mathbf{3 0}$. Quarterly average concentrations of ${ }^{137} \mathrm{Cs}$ in milk and air samples and the ${ }^{137} \mathrm{C}$ s deposited in precipitation are also shown. The data obtained in 1966 indicate that the average concentration of ${ }^{137} \mathrm{Cs}$ found in the 24-hr urine samples was comparable with that found in milk amples during the same anmpling period. Air and precipitation concentrations of ${ }^{137} \mathrm{Cs}$ continued to decline in 1966 in comparison with 1964 and 1965 levels. The measured 24-hr urine excretions of ${ }^{137} \mathrm{Cs}$ and corresponding body burdens of BXiL employees

Table 30

1966 BNL Environmental Mositoring

Comparion of Ires in Humans and in Environmental Media

\begin{tabular}{|c|c|c|c|c|c|c|c|c|}
\hline \multirow[b]{2}{*}{ Year } & \multirow[b]{2}{*}{ Qunrer } & \multirow[b]{2}{*}{$\begin{array}{l}\text { No. of } \\
\text { persons }\end{array}$} & \multirow[b]{2}{*}{$\begin{array}{c}\text { Av } \\
\text { body bunden, } \\
\text { pCi }\end{array}$} & \multicolumn{2}{|c|}{ Urine } & \multirow{2}{*}{ 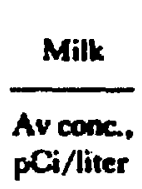 } & \multirow{2}{*}{$\frac{\text { Air }}{A v \cos x_{n} ;} \frac{1}{p\left(s / m^{2}\right.}$} & \multirow{2}{*}{$\frac{\text { Procipitation }}{\text { Activity, }}$} \\
\hline & & & & $\begin{array}{l}\text { At conc., } \\
\text { pCi/liter }\end{array}$ & $\begin{array}{l}\text { Av daily } \\
\text { excretion, } \\
\text { pCi }\end{array}$ & & & \\
\hline 1964 & $\begin{array}{l}\text { Ia } \\
\text { 2nd } \\
\text { 3rd } \\
\text { 4th }\end{array}$ & $\begin{array}{r}- \\
18 \\
8\end{array}$ & $\begin{array}{c}- \\
\overline{-} \\
16,300 \\
18,000\end{array}$ & $\begin{array}{l}-\overline{-} \\
134 \\
126\end{array}$ & $\begin{array}{l}- \\
\overline{187} \\
139\end{array}$ & $\begin{array}{l}194 \\
148 \\
128 \\
112\end{array}$ & $\begin{array}{l}0.070 \\
0.150 \\
0.057 \\
0.030\end{array}$ & $\begin{array}{r}12.3 \\
12.3 \\
4.3 \\
2.7\end{array}$ \\
\hline 1965 & $\begin{array}{l}\text { Int } \\
\text { 2nd } \\
\text { 3rd } \\
\text { 4th }\end{array}$ & $\begin{array}{r}13 \\
7 \\
6 \\
25\end{array}$ & $\begin{array}{l}13,300 \\
19,900 \\
27,100 \\
11,500\end{array}$ & $\begin{array}{r}100 \\
107 \\
96 \\
106\end{array}$ & $\begin{array}{r}98 \\
89 \\
120 \\
101\end{array}$ & $\begin{array}{r}101 \\
76 \\
64 \\
58\end{array}$ & $\begin{array}{l}0.035 \\
0.041 \\
0.020 \\
0.009\end{array}$ & $\begin{array}{l}2.4 \\
1.5 \\
1.3 \\
0.9\end{array}$ \\
\hline 1966 & $\begin{array}{l}\text { In } \\
\text { 2nd } \\
\text { 3rd } \\
\text { ith }\end{array}$ & $\begin{array}{l}36 \\
28 \\
15 \\
-\end{array}$ & $\begin{array}{r}10,760 \\
8,710 \\
9,320 \\
-\end{array}$ & $\begin{array}{l}66 \\
63 \\
64 \\
-\end{array}$ & $\begin{array}{l}72 \\
64 \\
74 \\
-\end{array}$ & $\begin{array}{l}60 \\
52 \\
45 \\
45\end{array}$ & $\begin{array}{l}0.010 \\
0.013 \\
0.011 \\
0.004\end{array}$ & $\begin{array}{l}1.5 \\
1.1 \\
0.8 \\
0.5\end{array}$ \\
\hline \multicolumn{3}{|c|}{ Emimated error, $\%$} & & & & \pm 10 & \pm 10 & \pm 10 \\
\hline
\end{tabular}


who participated during 1964 and 1965 are shown in Figure 19. It is evident that a single urine sample does not indicate body burdens within a factor of 2 .

\section{Mecurrement of Radioactivity in an Oak-Fine Ecesyatem}

A project unclertaken in cooperation with the Biology Department in the summer of 1966 involved $\gamma$-ray spectrometry on selected sumples from the Biology Department's ecology forest to determine the distribution of $\boldsymbol{\gamma}$-emitting radionuclides in an onk-pine ecosystem. The study is of particular intereat from an environmental monitoring standpoint because radioactive fallout becomes accumulated in plant parts mainly by direct aerial deposition and persistence in the environment may be important in the determination of radionuclide concentrations. The data have been published elsewhere. 25

\section{Salbetien of Memerimis for a Low-hockeround sued strield Does}

A large, low-background steel shield was acquired in June 1966. Its inner dimensions are $4 \times 4 \times 4 \mathrm{ft}$. The primary detector for this shield is a $5 \times 8$-in. Nal crystal. A second $5 \times 8$-in. cryatal will be added to improve counting geometry.

Prior to erecting the shield, a brief survey was made to select auitable materials to minimise the external $\gamma$ background from the concrete base now in use. Previous studies of the $\gamma$ activity in materials selected for the new low-level counting facility

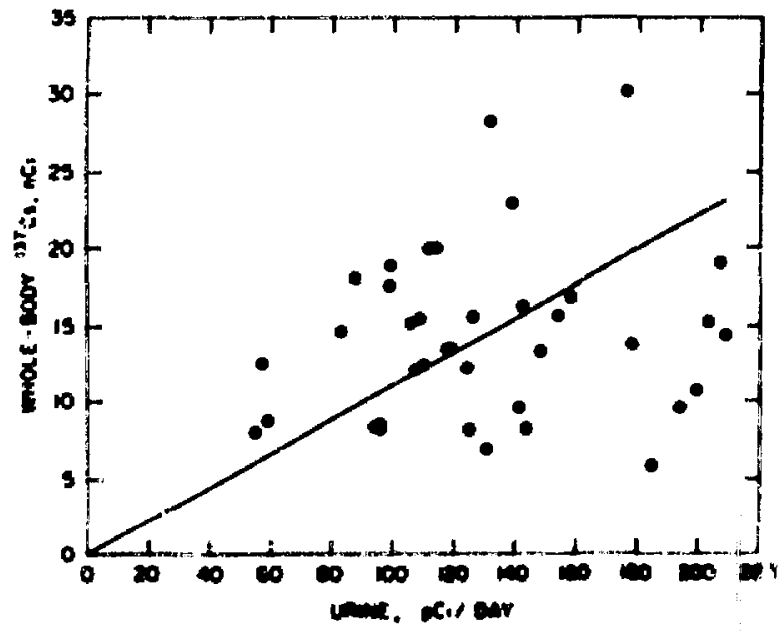

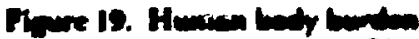

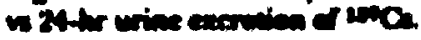

at the Brookhaven Medical Research Center ${ }^{26}$ and a study by Wollenberg and Smith ${ }^{27}$ for the Lawrence Radiation Laboratory Facility were utilized. This survey was confined to local stores or to nearby available materials that these studies indicated would be worth considering for low background.

Cement purchased locally was compared, on the basis of Wollenberg and Smith's study, with cement remaining from a large amount obtained from the British Columbia Cement Co. for the low-level counting facility. The data are shown in Table 31.

A study was made of the activity in on-site sands and gravels, sands and gravels from the nearby source selected for the Medical Facility, and the local stores of limonite and ilmenite. During the study a sample of ferrophosphate was unintentionally counted. The data (Table 31 ) suggeat that Serrophowphate (when protected from fallout, as that in the local store was not) ranks with the highdenaity materials inveatigated by Wollenberg and Smith as a low-background aggregate.

A comparion of the 600 -min background spectra obtained with two $4 \times 2$-in. Nal detectors in a amaller 6-in.-thick pre-World War II steel shield and with an $8 \times 5$-in. NaI detector in the new broce shield can be made from Figure 20. A rmall amount of "Co contamination is evident in the contemporary steel shield.

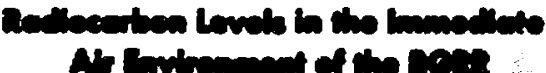

The DGRR produce ${ }^{14} \mathrm{C}$ by the $(n, p)$ reaction with the ${ }^{14 N}$ in its cooling air. In the summer of

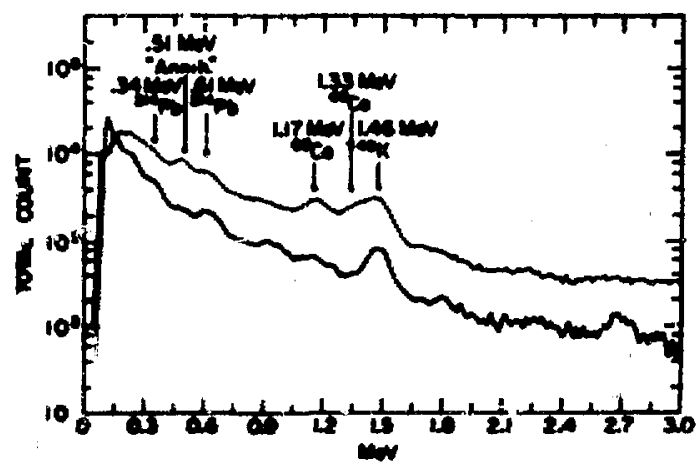

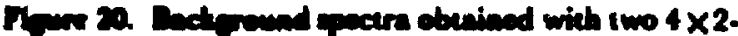

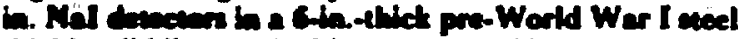

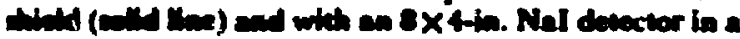

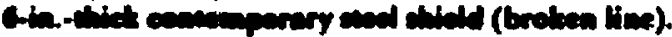


Table 31

1966 BNL Environmental Monitoring

Comparion of Cement and Aggregate Backgrounds

\begin{tabular}{|c|c|c|c|c|c|c|c|c|c|}
\hline \multirow[b]{2}{*}{ Material } & \multirow[b]{2}{*}{ Date } & \multicolumn{8}{|c|}{$\gamma / \mathrm{min} / \mathrm{kg}$ in principal photopeak regions } \\
\hline & & 0.24 & 0.36 & $\begin{array}{l}0.58 \\
\text { and } \\
0.60\end{array}$ & 0.66 & 0.91 & 1.44 & 1.76 & 2.62 \\
\hline $\begin{array}{r}\text { Gravel, BNL } \\
\text { Acme }\end{array}$ & $\begin{array}{l}3 / 20 \\
4 / 19\end{array}$ & $\begin{array}{l}126 \\
187\end{array}$ & $\begin{array}{l}210 \\
153\end{array}$ & $\begin{array}{l}183 \\
138\end{array}$ & $\begin{array}{l}<50 \\
<50\end{array}$ & $\begin{array}{l}50 \\
96\end{array}$ & $\begin{array}{r}1125 \\
725\end{array}$ & $\begin{array}{l}93 \\
75\end{array}$ & $\begin{array}{l}43 \\
56\end{array}$ \\
\hline $\begin{array}{r}\text { Sand, BNL } \\
\text { Acme }\end{array}$ & $\begin{array}{l}3 / 20 \\
4 / 19\end{array}$ & $\begin{array}{l}300 \\
169\end{array}$ & $\begin{array}{l}230 \\
153\end{array}$ & $\begin{array}{l}205 \\
157\end{array}$ & $\begin{array}{l}<50 \\
<50\end{array}$ & $\begin{array}{l}182 \\
141\end{array}$ & $\begin{array}{l}675 \\
589\end{array}$ & $\begin{array}{r}100 \\
<50\end{array}$ & $\begin{array}{r}137 \\
92\end{array}$ \\
\hline $\begin{array}{r}\text { Cernent, BNL } \\
\text { ELK }\end{array}$ & $\begin{array}{l}3 / 20 \\
5 / 6\end{array}$ & $\begin{array}{l}531 \\
131\end{array}$ & $\begin{array}{l}420 \\
115\end{array}$ & $\begin{array}{l}324 \\
222\end{array}$ & $\begin{array}{l}<50 \\
<50\end{array}$ & $\begin{array}{r}394 \\
66\end{array}$ & $\begin{array}{r}1000 \\
197\end{array}$ & $\begin{array}{r}120 \\
<50\end{array}$ & $\begin{array}{r}194 \\
<50\end{array}$ \\
\hline Limonite, BNL & $\begin{array}{l}4 / 6 \\
5 / 2\end{array}$ & $\begin{array}{r}87 \\
354\end{array}$ & $\begin{array}{l}113 \\
740\end{array}$ & $\begin{array}{l}217 \\
750\end{array}$ & $\begin{array}{l}<50 \\
<50\end{array}$ & $\begin{array}{l}<50 \\
<50\end{array}$ & $\begin{array}{l}180 \\
490\end{array}$ & $\begin{array}{l}121 \\
530\end{array}$ & $\begin{array}{l}<50 \\
<50\end{array}$ \\
\hline $\begin{array}{l}\text { Ilmenite } \\
\text { BNL } \\
\text { Twin County, fine } \\
\text { Twin County, medium }\end{array}$ & $\begin{array}{l}4 / 11 \\
4 / 27 \\
4 / 27\end{array}$ & $\begin{array}{l}88 \\
82 \\
95\end{array}$ & $\begin{array}{l}60 \\
68 \\
35 \\
42\end{array}$ & $\begin{array}{l}76 \\
26 \\
31 \\
53\end{array}$ & $\begin{array}{r}326 \\
97 \\
136 \\
200\end{array}$ & $\begin{array}{r}<50 \\
<50 \\
<50 \\
51\end{array}$ & $\begin{array}{r}168 \\
105 \\
96 \\
129\end{array}$ & $\begin{array}{l}<50 \\
<50 \\
<50 \\
<50\end{array}$ & $\begin{array}{l}<50 \\
<50 \\
<50 \\
<50\end{array}$ \\
\hline BNL, medium & $4 / 27$ & 133 & $<25$ & $<23$ & 88 & $<50$ & 19 & $<50$ & $<50$ \\
\hline Ferrophoephate, BNL & $\begin{array}{l}4 / 27 \\
5 / 4\end{array}$ & $\begin{array}{l}<50 \\
<50\end{array}$ & 27 & $<25$ & 86 & 50 & 32 & $<30$ & $<50$ \\
\hline
\end{tabular}

1966 a project ${ }^{23}$ was conducted to investigate the Reasibility of measuring the radiocarbon levels in the effluent cooling air and at ground level in the vicinity of the BGRR.

Air was drawn through glass fiber and halogen filters to remove particulates and halogens and then through a bubbler of the Greenberg-Smith type containing $0.5 N \mathrm{NaOH}$ solution to trap $\mathrm{CO}_{2}$. At the conclusion of the sampling period (24 to 72 hrs) BaCO, was precipitated from the sampling solution, dried, and powdered. It was then aupended in a scintillating gel and counted in a dual-channel liquid scintillation spectrometer.

Since this project was primarily feasibility study, the sampling parameter were not carefully cotabliched. An apparent 24-hr average ${ }^{14} \mathrm{C}$ atack concentration, based on approximations of these parameters, was $2 \times 10^{-8} \mu \mathrm{Ci} / \mathrm{cm}^{3}$ as compared with a calculated concentration of $6 \times 10^{-8}$ $\mathrm{MCi} / \mathrm{cm}^{2}$ (based on the observed ${ }^{11} \mathrm{Ar}$ emiscion).

During the same 24-hr period an apparent downwind concentration of $1 \times 10^{-10} \mu \mathrm{Ci} / \mathrm{cm}^{3}$ was fousd at station S-13. While this S-13 concentration was about kew of the Radiation Protection Standard for uncontrolled areas, it was at least 1000 times that calculated on the bavis of the stack effuent concentration and calculated diffusion. The reasons for this higher than anticipated ground-level concentration have not been atabliched.

\section{Wente end Rechmmetion Area Well Sumpling}

Samples of underground water were obtained from the well in the waste and reclamation (Igloo) area reported20 to have been accidentally contaminated with between 1.5 to $6 \mathrm{Ci}$ of old fixion products in the summer of 1960 . Sumples were alno obtained from a wet of wells $80 \mathrm{ft}$ downstream (so: theast) for the apparent direction of groundwater flow in this region. The distance to the top of the water table in this portion of the Laboracory site is about $15 \mathrm{ft}$ below grade. The original ampling data indicated that the maximum contamination was at 2 I ft below grade, or only a few Eet into the water table.

The grom $\beta$ concentrations obtained between 1960 and 1966 in thewe well are shown in Table 32. Some measurements of ${ }^{05}$ and ${ }^{137} \mathrm{Cs}$ concentra. tions were made in 1966, and theae data are included in the table. 
Table 32

1966 BNL Environmental Monitoring

Grow $\beta$ Concentration in Igloo Wells, pCi/liter

\begin{tabular}{|c|c|c|c|c|c|c|c|c|c|c|}
\hline \multirow{3}{*}{$\begin{array}{l}\text { Well } \\
\text { No. }\end{array}$} & \multirow{3}{*}{ Dintance, } & \multirow[b]{3}{*}{ Direction } & \multicolumn{6}{|c|}{ Grom $\beta$} & \multirow{2}{*}{\multicolumn{2}{|c|}{ Apr. 1966}} \\
\hline & & & & & & & & & & \\
\hline & & & $\begin{array}{l}\text { Nov. } \\
1960\end{array}$ & $\begin{array}{l}\text { Fed. } \\
1961\end{array}$ & 1961 & 1962 & 1963 & $\begin{array}{l}\text { Apr. } \\
1966\end{array}$ & $\operatorname{ses} r$ & ${ }^{137} \mathrm{C}$ \\
\hline 1 & 0 & - & $2.3 \times 10^{8}$ & $2.2 \times 10^{6 *}$ & $3.3 \times 10^{5}$ & $3.6 \times 10^{5}$ & $3.2 \times 10^{5}$ & 1010 & 24 & 1205 \\
\hline 10 & 80 & $155^{\circ}$ & 740 & 140 & - & - & - & 58 & 147 & - \\
\hline 13 & 80 & $157^{\circ}$ & $7.6 \times 10^{4}$ & 1700 & - & 350 & 94 & 24 & - & - \\
\hline 24 & 80 & $159^{\circ}$ & - & 3100 & - & 520 & 135 & 18 & - & - \\
\hline 14 & 80 & $160^{\circ}$ & $5.6 \times 10^{4}$ & $1.2 \times 10^{4}$ & 770 & - & 208 & 36 & - & - \\
\hline 23 & 80 & $162^{\circ}$ & 700 & $3.4 \times 10^{4}$ & 650 & 440 & 281 & 99 & - & 35 \\
\hline 22 & 80 & $163^{\circ}$ & 360 & 440 & 820 & 120 & 297 & $550^{*}$ & 126 & $<10$ \\
\hline 33 & 80 & $168^{\circ}$ & - & - & 160 & 60 & 167 & 111 & 77 & 22 \\
\hline
\end{tabular}

-Initial undiaturbed sample, prior to pumping, $76 \mathrm{pCi} /$ liter.

\section{ACKNOWLDOMENTS}

The assistance of Messrs. E. Hartmann and G. Warner and of Mrs. J. Nobile in the collection and procesaing of data is gratefully acknowledged. Two summer Public Health Service Fellowship trainees, J. Carey and R. Anger, conducted the Peconic River survey, and W. Van Pelt carried out the inveatigation of ${ }^{14} \mathrm{C}$ in the BGRR effluent air. The strontium and tritium analyaes weie performed by the Health Physics Division's Analytical Chemistry Section under the direction of J.R. Steimers. Meteorological consultation and cooperation were provided by M.E. Smith of the BNL Meteorology Group. The study of the ${ }^{137} \mathrm{C}$ s wholebody and urine levels was carried out in cooperation with S.M. Cohn of the BNL Medical Depertment. Off-aite sampling was conducted by $S$. Becker of the Suffolk County Health Department.

\section{Aringas}

1. A.P. HuLL, 1962 Enoinmonulal Ratidion Loods at Broathan Natimal Laberap, BNL 807 (T-310), Mny 19.33.

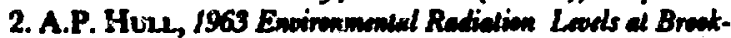
hean Natinal Lakndom, BNL 915 (T-376), Nov. 1964.

3. A.P. Hur., 1964 Enoinmmendal Radiation Loods al Brouthen Natimel Lateres, BNL 30001 (T-427), June 1966.

4. A.P. HuLl, 1965 Envirammontal Monitoring Radiation Lools al Brooktham National Laterctory, BNL 50093 (T-483), Sept. 1967.

5. Reported nuclear detonation, May 1966, Radiol. Hoult Dea 7, 376 (1966).
6. Reported nuclear detonations, October 1966, Ibid., 673.

7. J.B.H. Kupze and R.L. Gease, A monitor for lowintensity gamma raye, Reo. Sci. Justr. 21, 356-9 (1950).

8. U.S. Atomic Energy Commimion, Standards for Rariiation Prolection, Chapter 0524, ABC Manual, 1963.

9. E.P. Cowan and C.B. Menwold, Radiation donimetry for $\mathrm{Co}^{\mathrm{E}}$ and $\mathrm{C}^{131}$ gamma ray field irradiation facilitics, Radint. Botany 2, 241-9 (1962).

10. C.W. StLl and J.K. Flyoonn, Ja., Iodine monitoring at the National Reactor Teating Station, Heall Phys. 2, 261-8 (1960).

11. A.P. Hull, J.T. Gilmantin, and M.E. Sumth, The evaluation of fiacion product and activation isotopes in a reactor stack effluent and in the nearby environment, in Enoironmental Strocillance in the Vicinity of Nuclear Reacters, W.C. Reinig, Editor, Thoma, Springfield, IIt. (in preas).

12. Reported nuclear detonations, December 1966 , Rulid. Hailuk Dakn 8, 64 (1967).

13. P.W. KRnY, HASL Sugface Air Sanpling Pregrem Ganme

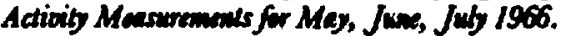

34. H.J. Rechen, Momkly Tabulation of Findings, UI.S. Public Hallh Smoice Radiation Surveillawa Natwiert, Mog, Oatere and Noomber 1966.

15. R.D. Grundy and D.R. Snavely, Fallout from the thind Chinese nuclear test, Radid. Healh Dula B, 301-16 (1967).

16. L. Machta, Status of global radionctive-fallout predictions, in Radicactive Fallout From Nucker Weapens Test, p. 381, CONF-765, US AEC, 1965.

17. A.P. Hull and M.E. Surth, Environmental monitoring of 181I as a verification of meteorological calculations of dispersion from a 100-meter atack, in Prac. Ist Int. Conpr. Ratiation Pratection, Roms, Sept. 1966, pp. 659-67, Pertamon, London, 1968.

18. Bupos, G,A., Private communication, 1968. 
19. E.P. Hasoy and J. Rivera, Appeondix bo Fallowe Program, Quartorly Summary Roport, March 1, 1967-June 1, 1967, Appendix B, HASL-182, July 1, 1967.

20. L. GrmmrLt, Efficiency of filter beds tor treating radionctive waste, Nuchmics 10, No. 10, 40-2 (1952).

21. J. Krikawa, BNL Plant Engineering and Planning Divicion, Personal communication, 1968.

22. Water Rewourcea Diviaion, U.S. Geological Survey (Albany, N.Y.), Waler Reseurces Date for New York, 1966, PL. 1, Surface Water Recourd, 1967.

23. R.H. Nejl., Wectly Swrocillaner Roports, U.S. Public Health Service, June 1, 8, 15, 22 and Nov. 2, 9, 16, $23,1966$.

24. Breokhaorn National Laboratong Safoty Menual, Pl. I, Radiation Sefely, Pp. 5-6, revied Aug. 1965.

25. R. Ronertson, M.S. 'Thevis, University of Iowa, Iowa City, 1967.
26. S.H. Cors, The whole-body counter in medical research and diagnouis, in Progress in Alomic Medicine, Chap. I, Pp. 8-10, J. Lawrence, Editor, Grune \& Stratton, New York, 1965.

27. H.A. Wolleneng AND A.R. Surth, Low Background Conce- UCRL 11674, 1964.

28. W.R. VAN Pelt, Investigation of the Carbon-14 Activity Levels in the Immediate Air Environment of the Brookhaven Graphite Reacarch Reactor, Internal Report, Health Physics Division, Brookhaven National Laboratory, Aug. 1966.

29. L. Gemmel and S.G. Pearenll, Tramsport of fiacion product through the wil following injection from a well and nethods uned for removal, in Int. Collog. Reunlion and Migration of Redinactive lons in Soils, Paris, Oct. 1962, pp. 199-206, CEN, TD-812, 1962. 